Supporting Information for

\title{
2-Aryl-5-carboxytetrazole as a New Photoaffinity Label for Drug Target Identification
}

András Herner, ${ }^{\dagger, 1}$ Jasmina Marjanovic $,{ }^{\ddagger}, 1$ Tracey M. Lewandowski, ${ }^{\dagger}$ Violeta Marin,${ }^{\ddagger}$ Melanie Patterson, ${ }^{\ddagger}$ Laura Miesbauer, ${ }^{\ddagger}$ Damien Ready, ${ }^{\ddagger}$ Jon Williams, ${ }^{\ddagger}$ Anil Vasudevan ${ }^{\ddagger},{ }^{*}$ and Qing Lin ${ }^{\dagger, *}$

†Department of Chemistry, State University of New York at Buffalo, Buffalo, New York 142603000, United States; ${ }^{*}$ Discovery Chemistry and Technology, AbbVie Inc., North Chicago, IL 60064-6101, United States; ${ }^{1}$ These authors contributed equally to this work.

E-mail: qinglin@buffalo.edu, anil.vasudevan@abbvie.com

\section{Table of Contents}

\section{Supplemental Tables and Figures}

Figure S1. HPLC-based study of quenching of ACT in acetonitrile/PBS $(1: 1) \ldots \ldots \ldots \ldots \ldots . . . . . . . . S 3$

Table S1. Kinome profiling of the Dasatinib probes.....................................................S4-S5

Table S2. Binding affinity and cell proliferation data for the JQ-1 probes .......................... S6

Figure S2. Labeling of recombinant BTK protein by Dasatinib probes .............................. S7

Figure S3. Labeling of recombinant BTK protein by Dasatinib probes in K562 cell lysate ... S7

Figure S4. Labeling of recombinant BRD4 protein by JQ-1 probes ................................... S8

Figure S5. Labeling of recombinant BRD4 protein by JQ-1 probes in K562 cell lysate........ S8

Figure S6. HPLC and LC-MS analyses of the photoactivation of $\mathbf{1 a}$ and $\mathbf{2 a}$ in PBS ......S9-S10

Figure S7. Inhibition of the ligand-dependent target cross-linking by the ACT-based probes as monitored by LC-MS

Figure S8. Concentration-dependent cross-linking of BRD4 protein by probe $\mathbf{4 a}$

Figure S9. Model studies of the quenching reactions of ACT

Figure S10. Model studies of the quenching of diaryltetrazole by glutamic acid.

.S18-S20

Figure S11. Western blot detection of the targets after the photoaffinity enrichment $\mathrm{S} 21$

Table S3. Kinases identified by LC-MS/MS using the photoaffinity labels 1a and 2a $\mathrm{S} 22$

Table S4. Proteins identified by LC-MS/MS using the photoaffinity labels $\mathbf{4 a}$ and $\mathbf{5 a}$

Table S5. Comparison of kinase targets identified by probes $\mathbf{1 a} / \mathbf{2 a}$ from this study with those from the literature. S24-S25

Table S6. Comparison of protein targets identified by probes $\mathbf{4 a / 5 a}$ from this study with those from the literature. S25

General Information S26

Experimental Procedures and Characterization Data S26-S37

${ }^{1} \mathrm{H}$ and ${ }^{13} \mathrm{C}$ NMR Spectra S38-S49 
a)

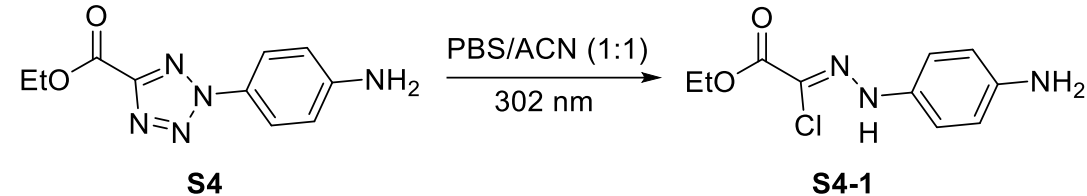

(100 $\mu \mathrm{M})$

b)
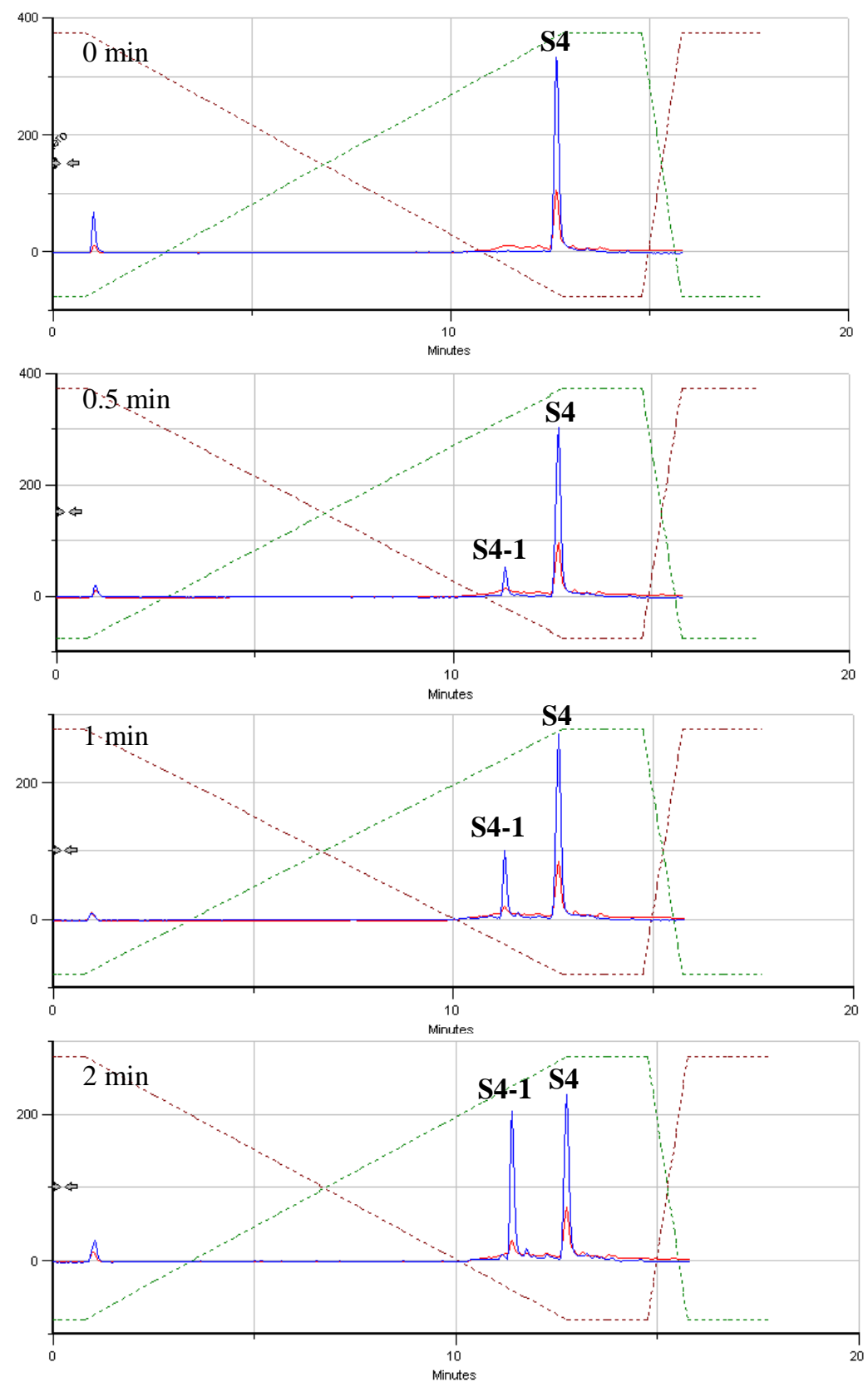


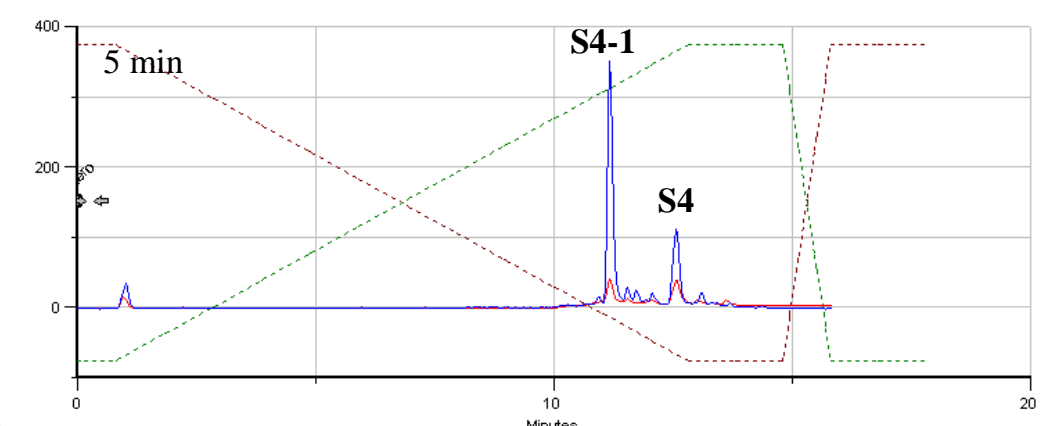

c)

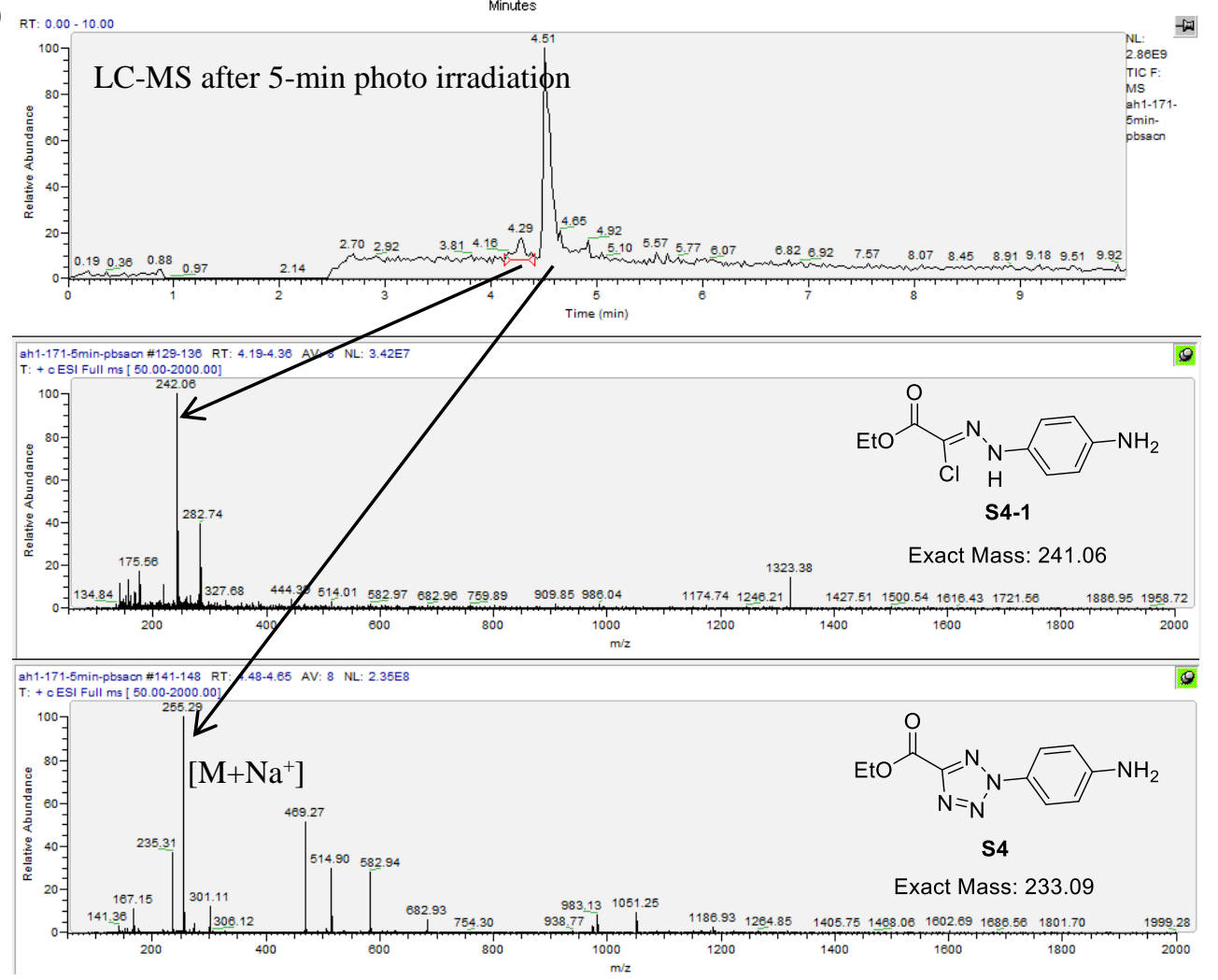

d)

\begin{tabular}{|c|c|c|}
\hline $\begin{array}{c}\text { Time } \\
(\mathrm{min})\end{array}$ & $\begin{array}{c}\text { \% starting } \\
\text { materials }\end{array}$ & $\begin{array}{c}\text { \% quenching } \\
\text { product }\end{array}$ \\
\hline 0 & 100 & 0 \\
\hline 0.5 & 88.4 & 11.6 \\
\hline 1 & 77.2 & 22.8 \\
\hline 2 & 57.0 & 43.0 \\
\hline 5 & 28.5 & 71.5 \\
\hline
\end{tabular}

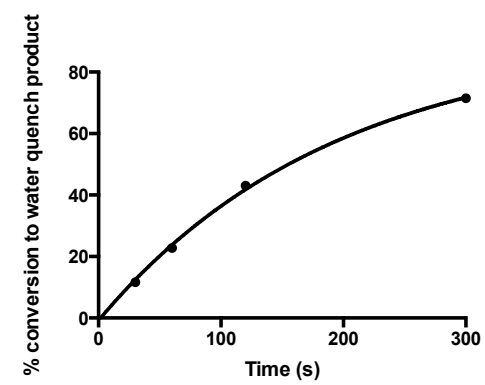

Figure S1. HPLC-based study of the medium-quenching of ACT S4 $(100 \mu \mathrm{M})$ in acetonitrile/PBS $\left(1: 1,70 \mathrm{mM} \mathrm{Cl}^{-}, \mathrm{pH} 7.5\right)$ under $302 \mathrm{~nm}$ photoirradiation. (a) Reaction scheme. (b) Time course of the quenching reaction after $0,0.5,1,2$, and 5-min photoirradiation monitored by reverse-phase HPLC. Red traces = absorbance at $254 \mathrm{~nm}$; blue traces $=$ absorbance at $365 \mathrm{~nm}$. (c) Plot of percent conversion vs. photoirradiation time. The data were fitted to an exponential rise to maximum equation using: $y=\left(y_{0}-a\right) e^{-k_{o b s} t}+a$, to give $k_{\mathrm{obs}}=0.005178 \pm 0.0013 \mathrm{~s}^{-1}$, with $\mathrm{R}^{2}=0.9988$. 
Table S1. Kinome profiling of the Dasatinib probes.

\begin{tabular}{|c|c|c|c|c|c|c|c|}
\hline kinase & Das & $1 \mathrm{a}$ & $1 \mathrm{~b}$ & $2 \mathbf{a}$ & $2 \mathrm{~b}$ & 3a & $\mathbf{3 b}$ \\
\hline Abl & 0.0004 & 0.0020 & 0.0007 & 0.0004 & 0.0004 & 0.0077 & 0.0036 \\
\hline ACVR1 & 0.122 & 4.6900 & 0.2580 & 4.3300 & 0.4400 & 4.6900 & 4.6900 \\
\hline Akt1 & 5.01 & 4.0700 & 4.0700 & 4.0700 & 4.0700 & 4.0700 & 4.0700 \\
\hline ALK & 5.79 & 4.7700 & 4.7700 & 4.7700 & 4.7700 & 4.7700 & 4.7700 \\
\hline AUR1 & 2.81 & 5.5100 & 5.5100 & 5.5100 & 5.5100 & 5.5100 & 5.5100 \\
\hline AUR2 & 4.98 & 4.9800 & 2.9900 & 4.9800 & 4.9800 & 4.9800 & 4.9800 \\
\hline BRAF & 0.022 & 0.4090 & 0.0909 & 0.1120 & 0.0473 & 2.5000 & 2.5000 \\
\hline BTK & 0.0005 & 0.0067 & 0.0034 & 0.0014 & 0.0014 & 0.0613 & 0.2260 \\
\hline CAMK1D & 5.48 & 5.4800 & 4.0200 & 5.4800 & 5.4800 & 5.4800 & 5.4800 \\
\hline CAMK2A & 3.63 & 3.6300 & 3.6300 & 3.6300 & 3.6300 & 3.6300 & 3.6300 \\
\hline CAMKK2 & 4.96 & 4.9600 & 4.9600 & 4.9600 & 4.9600 & 4.9600 & 4.9600 \\
\hline CDK2 & 5.15 & 5.1500 & 5.1500 & 5.1500 & 5.1500 & $\mathrm{NV}$ & $\mathrm{NV}$ \\
\hline CDK7 & 5.05 & 5.0500 & 5.0500 & 5.0500 & 5.0500 & $\mathrm{NV}$ & $\mathrm{NV}$ \\
\hline CDK8 & 5 & 5.0000 & 5.0000 & 5.0000 & 5.0000 & 5.0000 & 5.0000 \\
\hline CDK9 & 1.91 & 3.5100 & 3.4600 & 4.8700 & 4.8700 & NV & NV \\
\hline Ck1 alpha1 & 4.28 & 6.2500 & 6.2500 & 6.2500 & 6.2500 & 6.2500 & 6.2500 \\
\hline CLK2 & 3.84 & 4.6400 & 4.6400 & 4.6400 & 4.6400 & 4.6400 & 4.6400 \\
\hline cMET & 4.93 & 4.0200 & 2.6000 & 4.9300 & 4.9300 & 4.9300 & 4.9300 \\
\hline CSF1R & 0.000486 & 0.0014 & 0.0004 & 0.0004 & 0.0005 & 0.0120 & 0.0033 \\
\hline DDR1 & 0.0149 & 0.0137 & 0.0044 & 0.0023 & 0.0015 & 0.1100 & 0.0116 \\
\hline Dyrk1A & 2.08 & 5.1200 & 4.9800 & 5.1200 & 5.1200 & 5.1200 & 5.1200 \\
\hline DYRK1B & 3.56 & 3.5600 & 1.7100 & 3.5600 & 3.5600 & 3.5600 & 3.5600 \\
\hline EGFR & 3.31 & 4.4900 & 2.4400 & 4.4900 & 2.0400 & 4.4900 & 4.4900 \\
\hline Erk2 & 5.93 & 5.3300 & 5.3300 & 5.3300 & 5.3300 & 5.3300 & $\mathrm{NV}$ \\
\hline FAK & 5.36 & 5.3600 & 5.3600 & 5.3600 & 5.3600 & 5.3600 & 5.3600 \\
\hline FGFR1 & 1.66 & 6.4400 & 2.5300 & 6.4400 & 6.4400 & 6.4400 & 6.4400 \\
\hline FLT1 & 2.21 & 5.3500 & 5.3500 & 5.3500 & 5.3500 & 5.3500 & 5.3500 \\
\hline Fyn & 0.00049 & 0.0051 & 0.0013 & 0.0008 & 0.0009 & 0.0303 & 0.0166 \\
\hline GRK5 & 4.42 & 5.6000 & 4.0700 & 5.6000 & 5.6000 & 5.6000 & NV \\
\hline GSK3 $\alpha$ & 4.87 & 4.8700 & 4.8700 & 4.8700 & 4.8700 & 4.8700 & 4.8700 \\
\hline GSK3 $\beta$ & 5.97 & 5.9700 & 5.9700 & 5.9700 & 5.9700 & 5.9700 & 5.9700 \\
\hline IGF1R & 2.65 & 3.7200 & 3.7200 & 3.7200 & 3.7200 & 3.7200 & 3.7200 \\
\hline IKKE & 4.73 & 4.7300 & 4.7300 & 4.7300 & 4.7300 & 4.7300 & 4.7300 \\
\hline InsR & 3.78 & 7.0700 & 7.0700 & 7.0700 & 7.0700 & 7.0700 & 6.8400 \\
\hline JAK2 & 1.23 & 4.5900 & 3.8800 & 4.5900 & 2.8100 & 4.5900 & 4.5900 \\
\hline JAK3 & 2.63 & 4.9800 & 4.9800 & 4.9800 & 4.9800 & 4.9800 & 4.9800 \\
\hline JNK1 & 5.11 & 5.1100 & 5.1100 & 5.1100 & 5.1100 & 5.1100 & 5.1100 \\
\hline JNK2 & 6.68 & 6.6800 & 6.6800 & 6.6800 & 6.6800 & 6.6800 & 6.6800 \\
\hline Kdr & 1.23 & 3.5400 & 3.5400 & 3.5400 & 3.5400 & 3.5400 & 3.5400 \\
\hline Lck & 0.0004 & 0.0120 & 0.0042 & 0.0020 & 0.0014 & 0.0691 & 0.0588 \\
\hline
\end{tabular}




\begin{tabular}{|c|c|c|c|c|c|c|c|}
\hline LTK & 2.77 & 4.2100 & 4.2800 & 4.2800 & 4.2800 & 4.2200 & 4.2800 \\
\hline MAP2K3 & 3.1 & 4.0400 & 3.3200 & 4.0400 & 4.0400 & 4.0400 & NV \\
\hline MAP3K10 & 1.4 & 5.5300 & 5.5300 & 5.5300 & 5.5300 & 5.5300 & 5.5300 \\
\hline MAP4K1 & 0.768 & 3.9900 & 3.6100 & 3.9900 & 3.9900 & 3.9900 & NV \\
\hline MAP4K2 & 1.07 & 2.3700 & 2.3700 & 2.3700 & 2.3700 & 2.3700 & 2.3700 \\
\hline MAP4K4 & 3.09 & 4.9400 & 4.9400 & 4.9400 & 4.9400 & 4.9400 & 4.9400 \\
\hline MEK1 & 0.696 & 4.8300 & 3.5200 & 4.8300 & 3.3500 & 4.8300 & NV \\
\hline MEK2 & 0.881 & 5.2800 & 5.2800 & 5.2800 & 4.8200 & 5.2800 & 5.2800 \\
\hline MST1 & 2.66 & 3.6500 & 3.6500 & 3.6500 & 3.6500 & 3.6500 & 3.6500 \\
\hline Nek2 & 1.88 & 5.1800 & 5.1800 & 5.1800 & 5.1800 & 5.1800 & 5.1800 \\
\hline p38 alpha & 0.0624 & 0.0387 & 0.0932 & 0.1480 & 0.0292 & 4.9500 & 0.2860 \\
\hline PAK4KD & 4.39 & 4.3900 & 4.3900 & 4.3900 & 3.6800 & 4.3900 & 4.3900 \\
\hline PDGFRA V561D & 0.00273 & 0.0293 & 0.0067 & 0.0060 & 0.0052 & 0.2860 & 0.1550 \\
\hline PDGFRB & 0.00195 & 0.0155 & 0.0063 & 0.0063 & 0.0025 & 0.3110 & 0.6370 \\
\hline Pim1 & 5.68 & 5.5900 & 5.5900 & 5.5900 & 5.5900 & 5.5900 & 5.5900 \\
\hline Pim2 & 4.19 & 5.0200 & 5.0200 & 5.0200 & 5.0200 & 5.0200 & 5.0200 \\
\hline PKA & 4.89 & 4.8900 & 4.8900 & 4.8900 & 4.8900 & 4.8900 & 4.8900 \\
\hline PKC theta & 3.86 & 1.5100 & 3.8600 & 3.8600 & 3.8600 & 3.8600 & 3.8600 \\
\hline PKC zeta & 1.99 & 4.5800 & 4.5800 & 4.5800 & 4.5800 & 4.5800 & $\mathrm{NV}$ \\
\hline PKG1A & 4 & 4.0000 & 4.0000 & 4.0000 & 4.0000 & 4.0000 & 4.0000 \\
\hline Plk3 & 1.55 & 3.7000 & 3.7000 & 3.7000 & 3.7000 & 3.7000 & 3.7000 \\
\hline Prken & 3.73 & 2.7600 & 2.7600 & 2.7600 & 2.7600 & 2.7600 & $\mathrm{NV}$ \\
\hline RET & 0.342 & 4.6000 & 1.2400 & 4.6000 & 1.4600 & 4.6000 & 4.6000 \\
\hline RIPK2 & 0.0028 & 0.0243 & 0.0109 & 0.0065 & 0.0037 & 0.3920 & 0.1070 \\
\hline Rock1 & 4.61 & 4.6100 & 4.6100 & 4.6100 & 4.6100 & 4.6100 & 4.6100 \\
\hline Rock2 & 5.28 & 5.2800 & 5.2800 & NV & 5.2800 & 4.8100 & 5.2800 \\
\hline Rsk2 & 4.64 & 4.6400 & 4.6400 & 4.6400 & 4.6400 & 4.6400 & 4.6400 \\
\hline SGK1 & 5.17 & 5.1700 & 5.1700 & 5.1700 & 5.1700 & 5.1700 & 5.1700 \\
\hline SIK1 & 0.000565 & 0.0042 & 0.0027 & 0.0010 & 0.0006 & 0.0431 & 0.0921 \\
\hline Src & 0.000582 & 0.0051 & 0.0014 & 0.0009 & 0.0007 & 0.0316 & 0.0215 \\
\hline STK16 & 4.6 & 4.6000 & 4.6000 & 4.6000 & 4.6000 & 4.6000 & 4.6000 \\
\hline STK33 & 2.02 & 2.7000 & 2.7000 & 2.7000 & 2.7000 & 2.7000 & 2.7000 \\
\hline Syk CatDom & 0.343 & 3.3000 & 2.2400 & 3.3000 & 3.3000 & 3.3000 & 3.3000 \\
\hline TAOK2 & 2.23 & 4.0000 & 2.0700 & 2.8400 & 0.5150 & 4.0000 & 4.0000 \\
\hline TBK1 & 3.27 & 4.0400 & 4.0400 & 4.0400 & 4.0400 & 4.0400 & 4.0400 \\
\hline TNK2 & 0.00192 & 0.0105 & 0.0047 & 0.0028 & 0.0033 & 0.1360 & 0.1800 \\
\hline TrkA & 4.71 & 4.7100 & 4.7100 & 4.7100 & 4.7100 & 4.7100 & 4.7100 \\
\hline TrkB & 5.3 & 5.3000 & 5.3000 & 5.3000 & 5.3000 & 5.3000 & 5.3000 \\
\hline TrkC & 3.44 & 4.6500 & 4.6500 & 4.6500 & 4.6500 & 4.6500 & 4.6500 \\
\hline TYRO3 & 1.75 & 4.9800 & 3.3300 & 4.9800 & 4.6700 & 4.9800 & 4.9800 \\
\hline Wee1 & 0.0635 & 0.4650 & 0.2640 & 0.4710 & 0.0445 & 4.4000 & 4.4000 \\
\hline Zipk & 5.41 & 5.7100 & 5.7100 & 5.7100 & 5.7100 & 5.7100 & NV \\
\hline
\end{tabular}

$K_{\mathrm{i}}$ values are given in $\mu \mathrm{M}$. Targets and off-targets are colored in blue. $\mathrm{NV}=$ no value. 
Table S2. Binding affinity and cell proliferation data for the JQ-1 probes.

\begin{tabular}{|c|c|c|c|c|c|c|}
\hline \multirow{2}{*}{} & \multicolumn{3}{|c|}{ Binding Assay } & \multicolumn{3}{c|}{ Cell Proliferation Titer-Glo Assay } \\
\cline { 2 - 7 } & BRD2 & BRD3 & BRD4 & $\begin{array}{c}\text { Human } \\
\text { MX-1 }\end{array}$ & $\begin{array}{c}\text { Human } \\
\text { NCI-H1299 }\end{array}$ & $\begin{array}{c}\text { Human } \\
\text { SKM-1 }\end{array}$ \\
\hline$(+)-J Q-1$ & 0.006 & 0.019 & 0.023 & 0.144 & 0.192 & 0.064 \\
\hline $\mathbf{4 a}$ & 0.002 & 0.004 & 0.004 & 1.380 & 7.140 & 0.031 \\
\hline $\mathbf{4 b}$ & 0.007 & 0.007 & 0.012 & 1.950 & $>10.000$ & 0.110 \\
\hline $\mathbf{5 a}$ & 0.022 & 0.019 & 0.055 & 1.51 & 6.74 & 0.231 \\
\hline $\mathbf{6 a}$ & 0.006 & 0.018 & 0.022 & 2.030 & 0.911 & 0.067 \\
\hline $\mathbf{6 b}$ & 0.002 & 0.014 & 0.002 & N/A & N/A & N/A \\
\hline
\end{tabular}

$\mathrm{N} / \mathrm{A}=$ not available. 


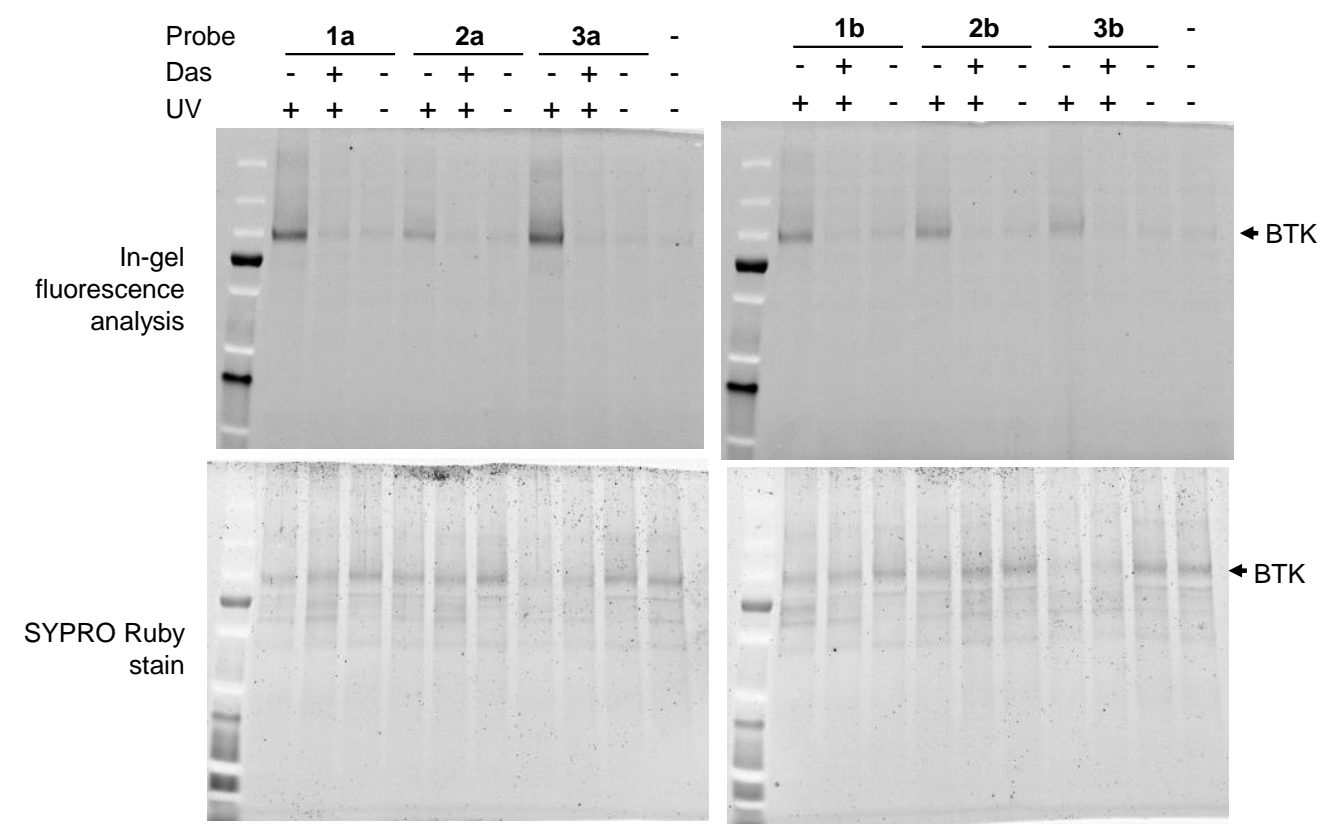

Figure S2. Full-size gel images of the labeling of recombinant BTK protein by the Dasatinibderived photoaffinity probes.

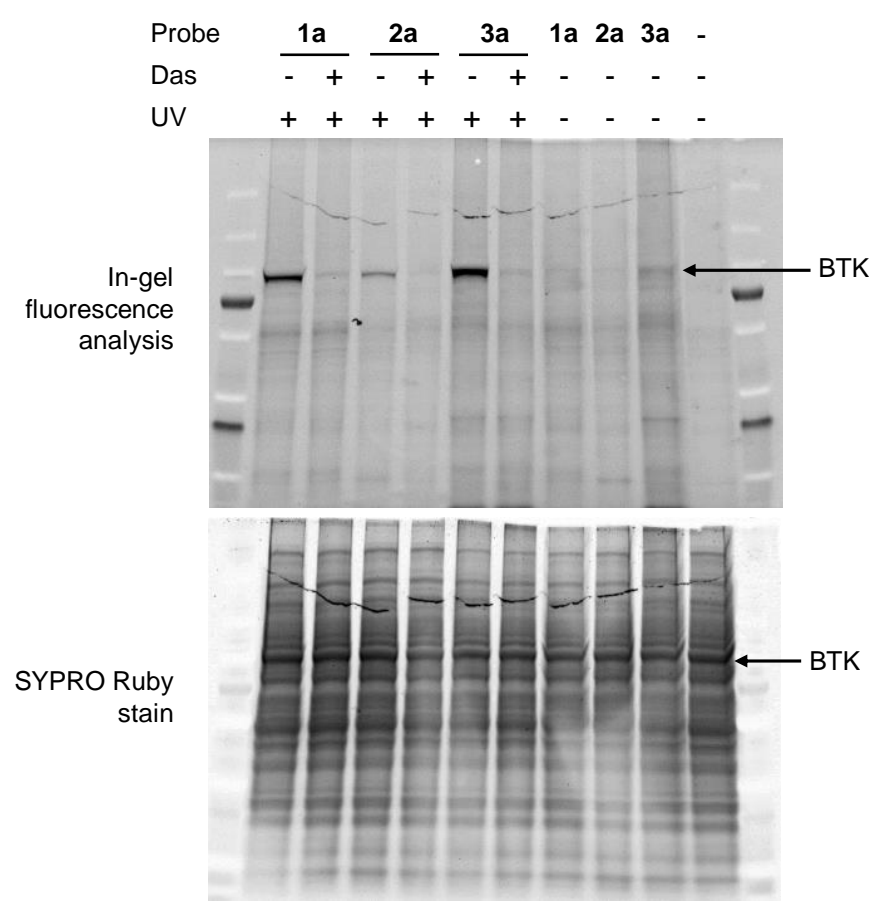

Figure S3. Selectively labeling of recombinant BTK protein by Dasatinib probes 1a, 2a and 3a in the K562 cell lysate spiked with recombinant BTK protein. For the competition reactions, $0.2 \mu \mathrm{M}$ of photoaffinity probe and $10 \mu \mathrm{M}$ of Dasatinib were used. 


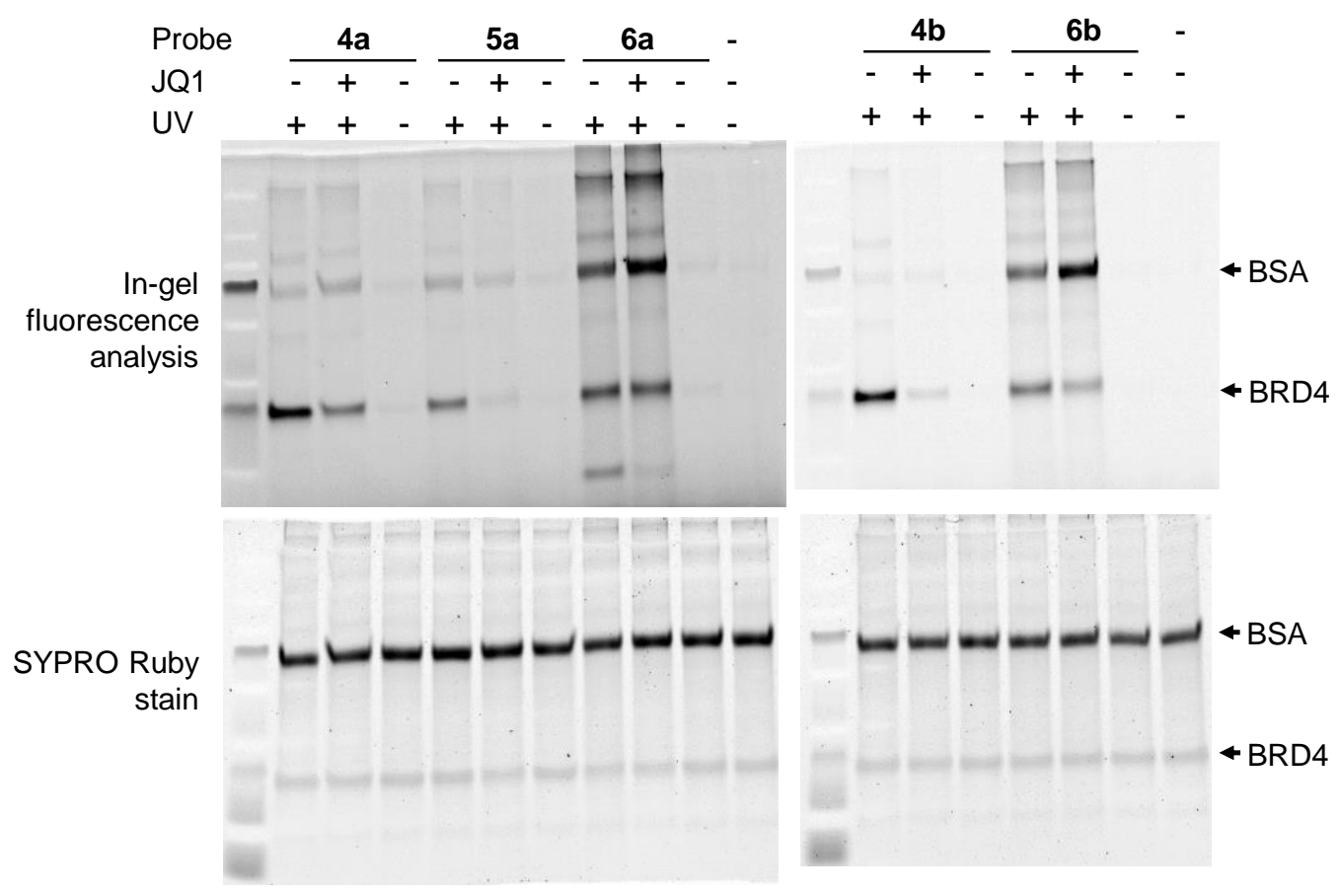

Figure S4. Full-size gel images of the labeling of recombinant BRD4 protein by the JQ-1derived photoaffinity probes.

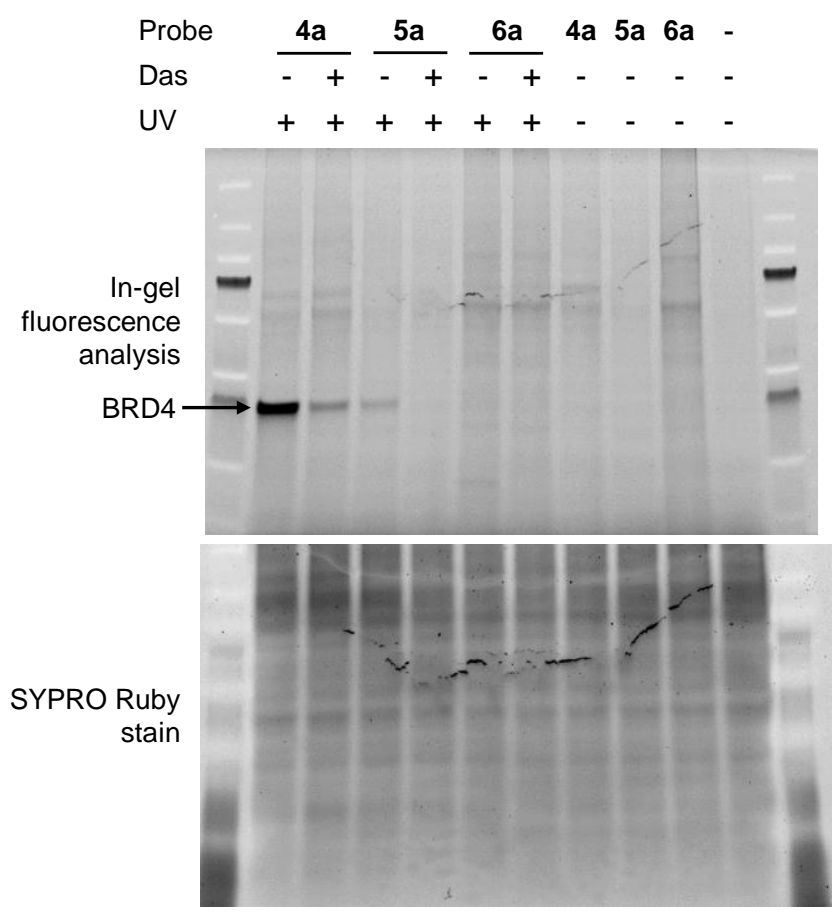

Figure S5. Labeling of recombinant BRD4 protein by JQ-1-derived photoaffinity probes $\mathbf{4 a}, \mathbf{5 a}$ and $\mathbf{6 a}$ in the. K562 cell lysate spiked with recombinant BRD4 protein. 
a)
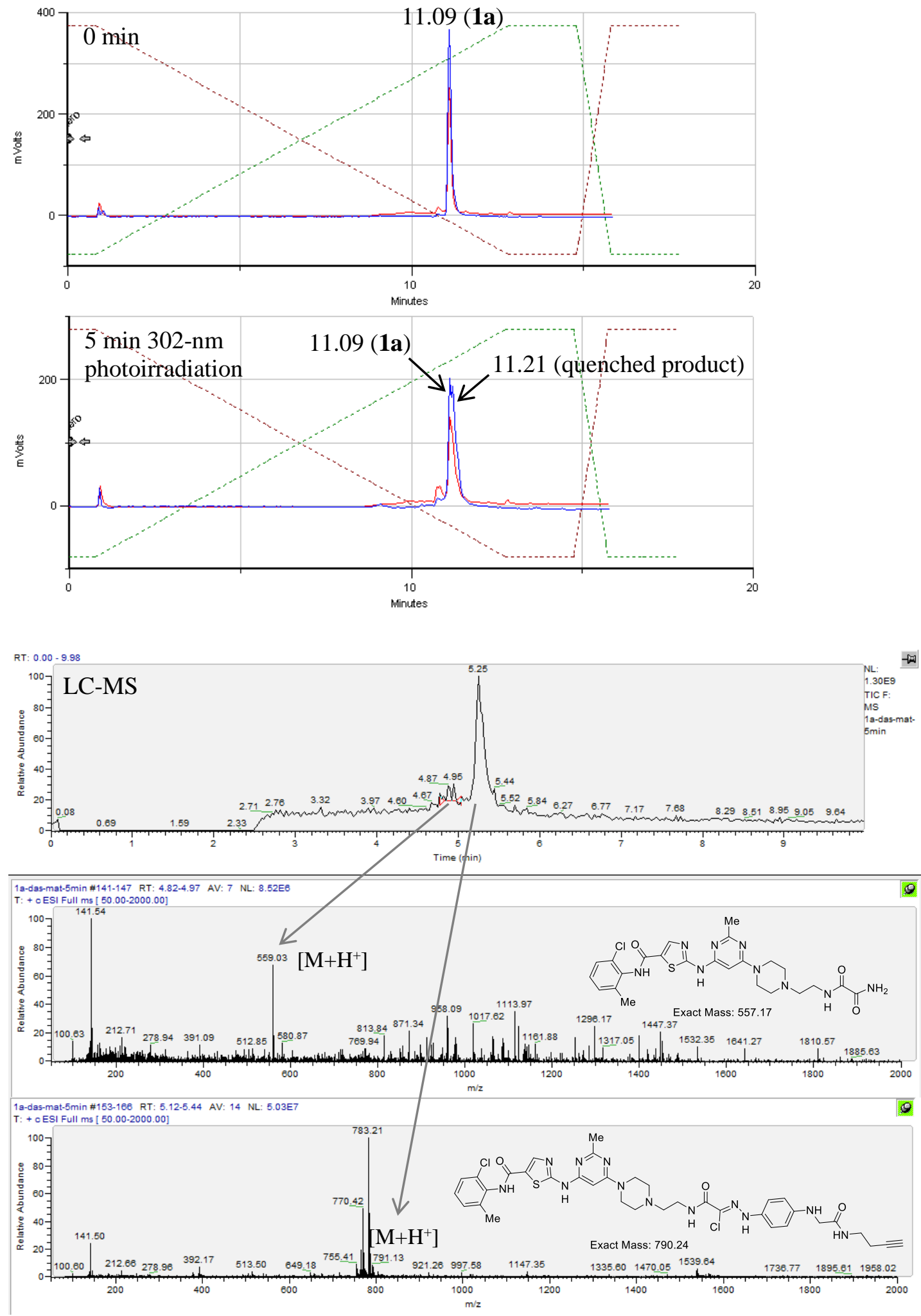
b)
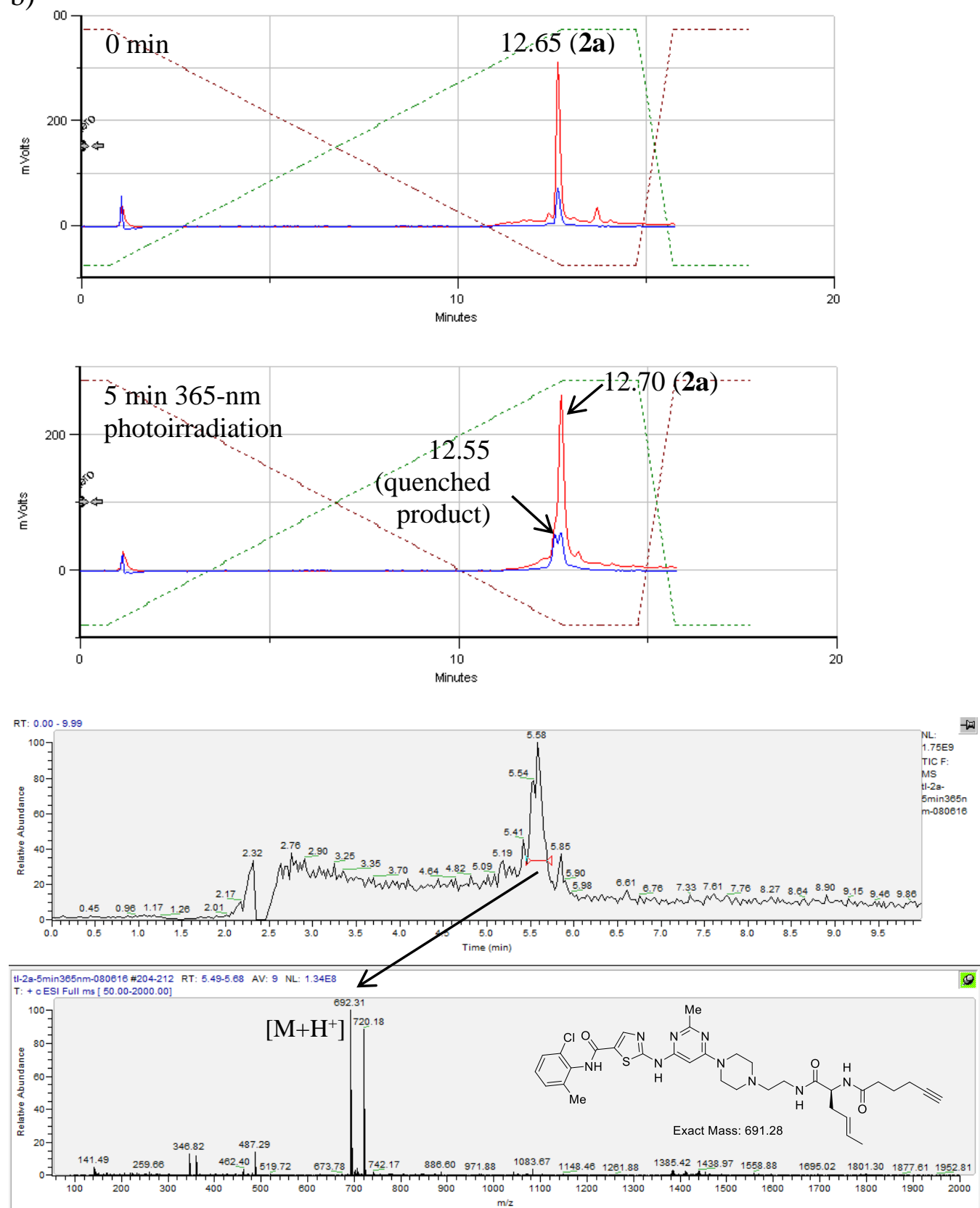

Figure S6. HPLC and LC-MS analyses of the photoactivation of (a) 1a and (b) $\mathbf{2 a}(100 \mu \mathrm{M})$ in PBS. Red trace $=$ absorbance at $254 \mathrm{~nm}$; blue trace $=$ absorbance a $365 \mathrm{~nm}$. The percent conversion was calculated to be $38 \%$ for $\mathbf{1 a}$ and $44 \%$ for $\mathbf{2 a}$ based on absorbance at $365 \mathrm{~nm}$. 
a)
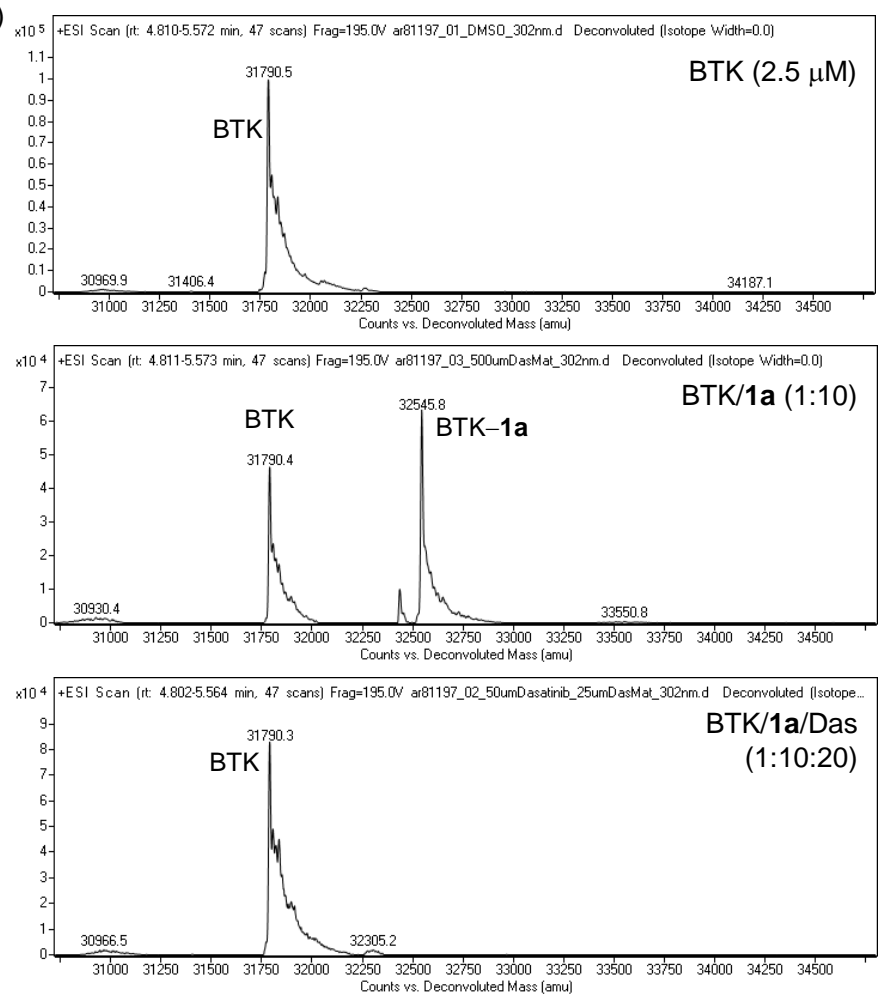

b)
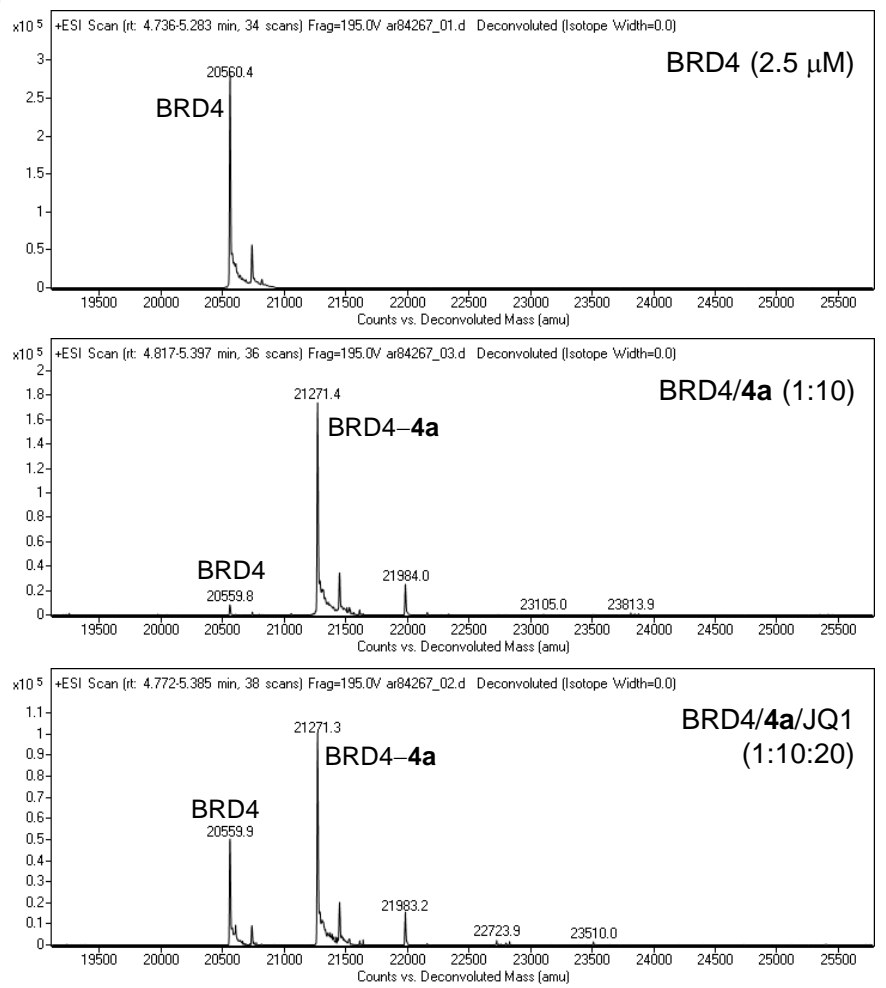

Figure S7. Inhibition of the ligand-dependent target cross-linking by the ACT-based probes as monitored by LC-MS. (a) Addition of Dasatinib $(50 \mu \mathrm{M})$ completely abolished the labeling of BTK $(2.5 \mu \mathrm{M})$ by probe 1a $(25 \mu \mathrm{M})$. (b) Addition of JQ-1 $(50 \mu \mathrm{M})$ significantly reduced the labeling of BRD4 $(2.5 \mu \mathrm{M})$ by probe $4 \mathbf{a}(25 \mu \mathrm{M})$. 

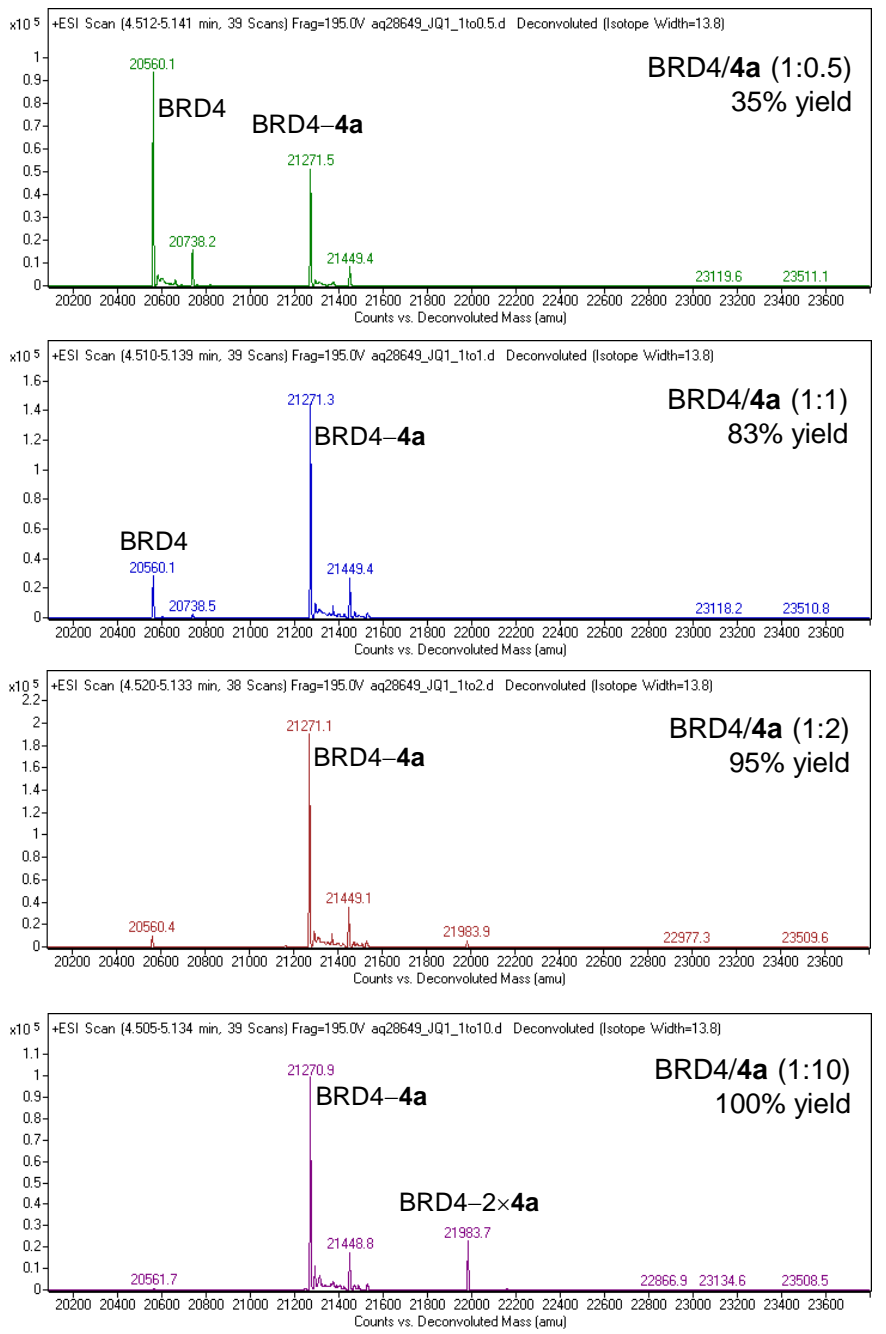

Figure S8. Concentration-dependent cross-linking of recombinant BRD4 protein by probe 4a as monitored by LC-MS. The concentration of BRD4 used in the reactions was $2.5 \mu \mathrm{M}$. 
a)

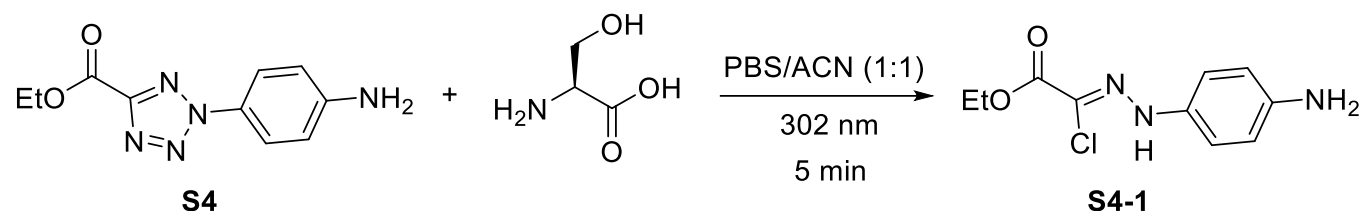

$(100 \mu \mathrm{M})$

(10 mM)
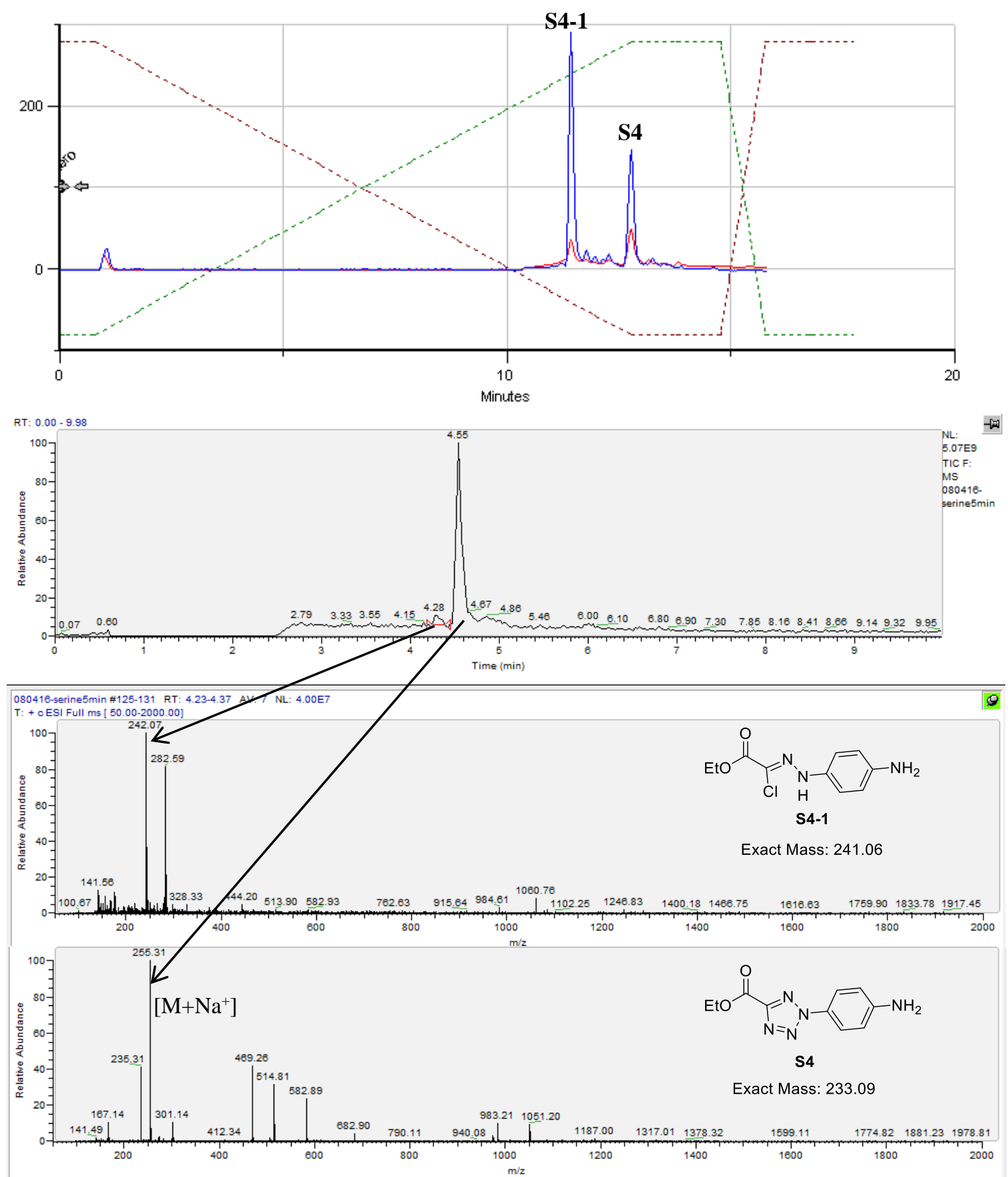
b)

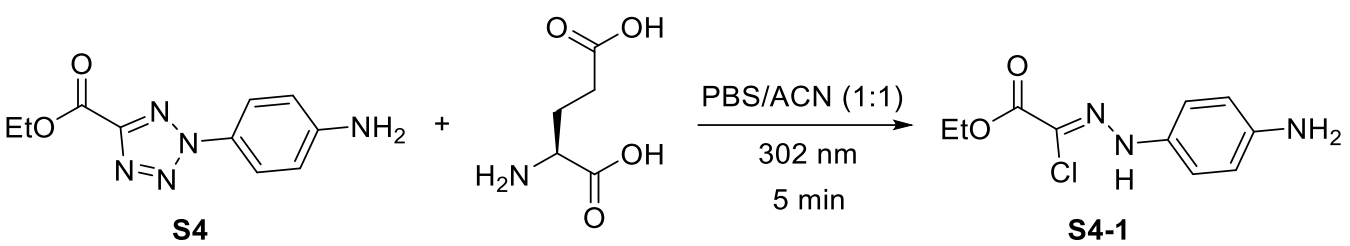

(10 mM)
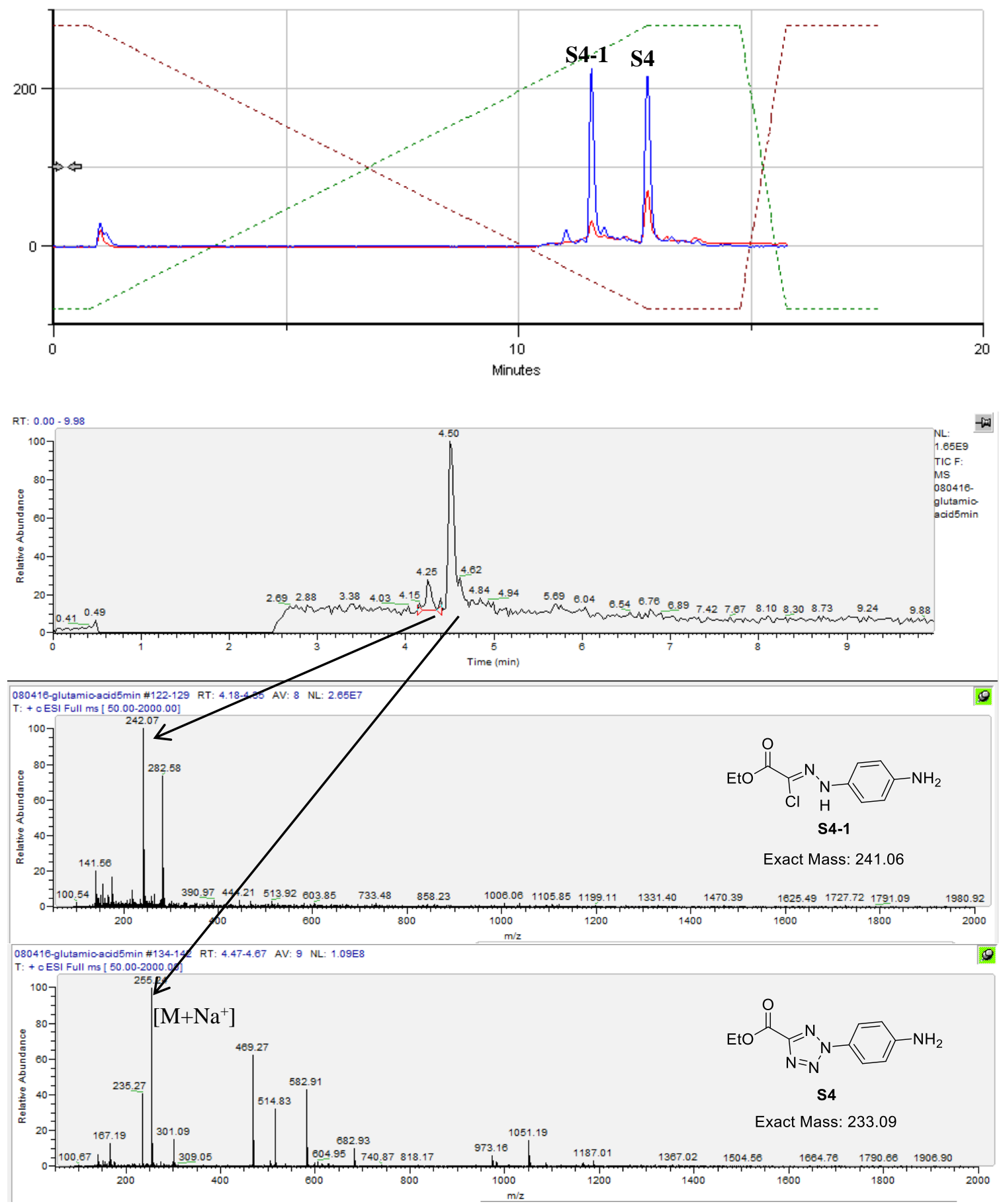
c)
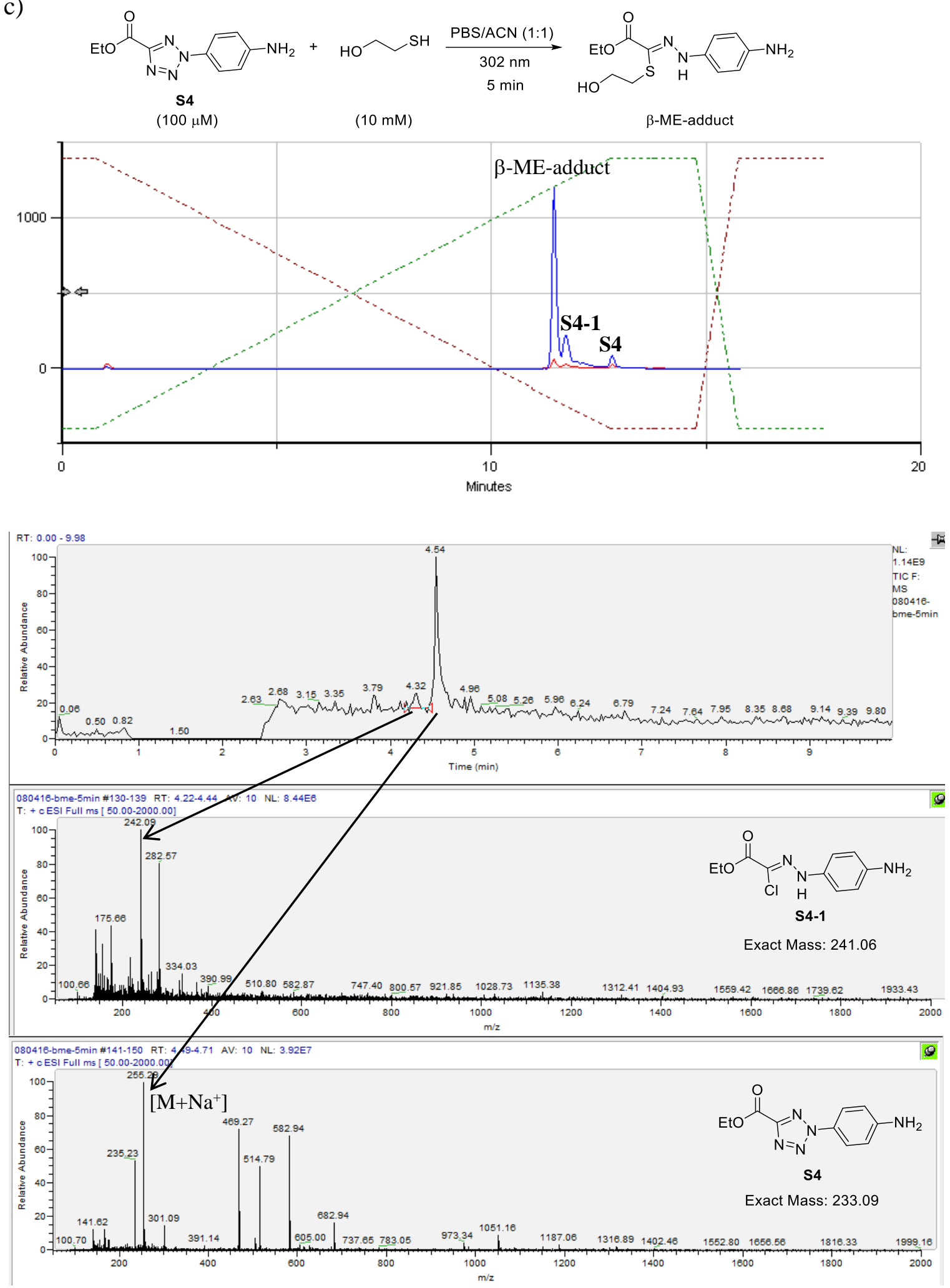
d)

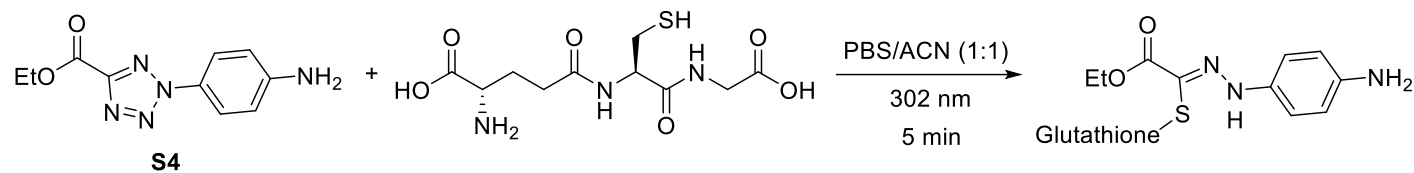
$\begin{array}{lll}(100 \mu \mathrm{M}) & (10 \mathrm{mM}) & \text { GSH-adduct }\end{array}$
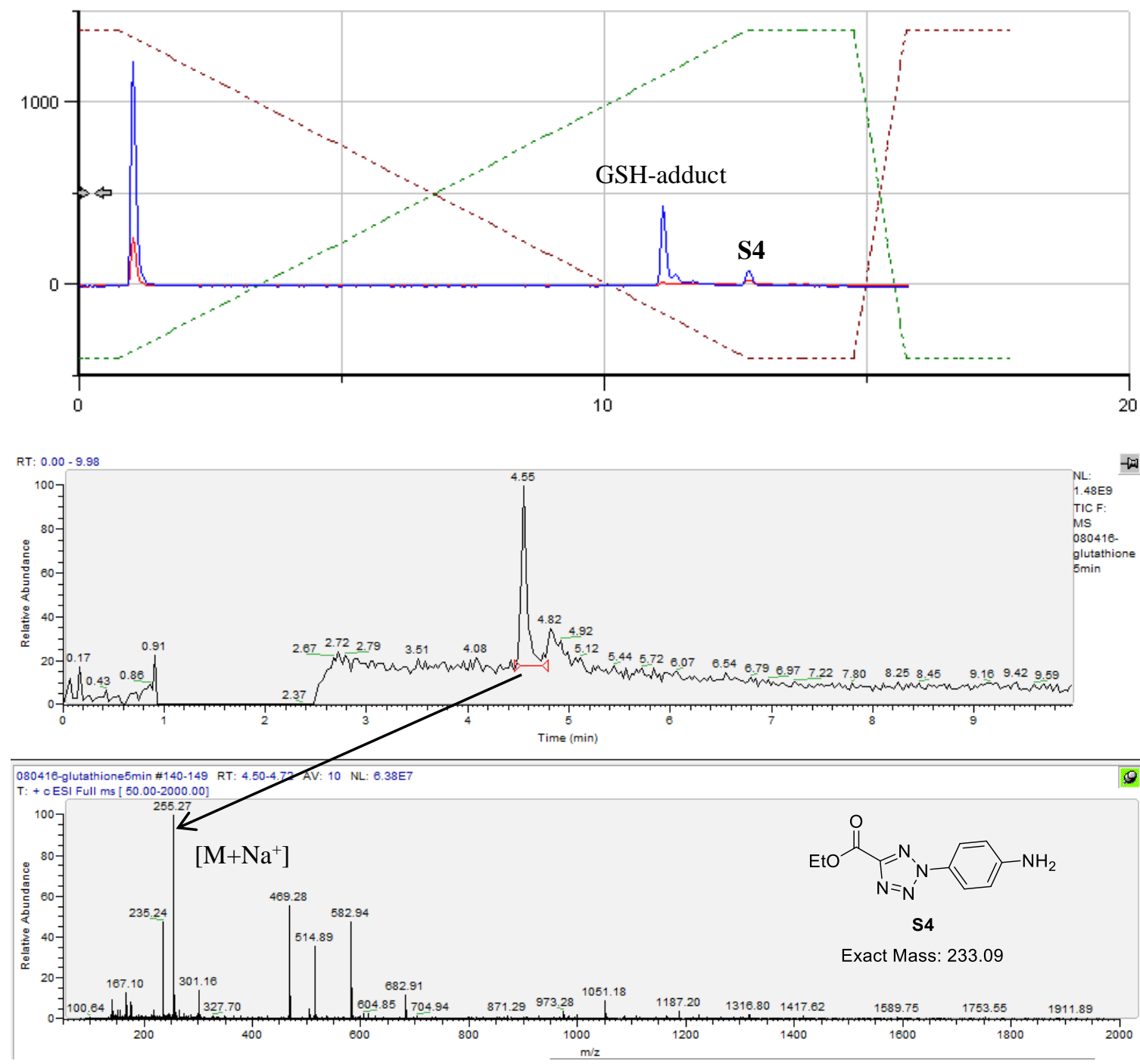

e)

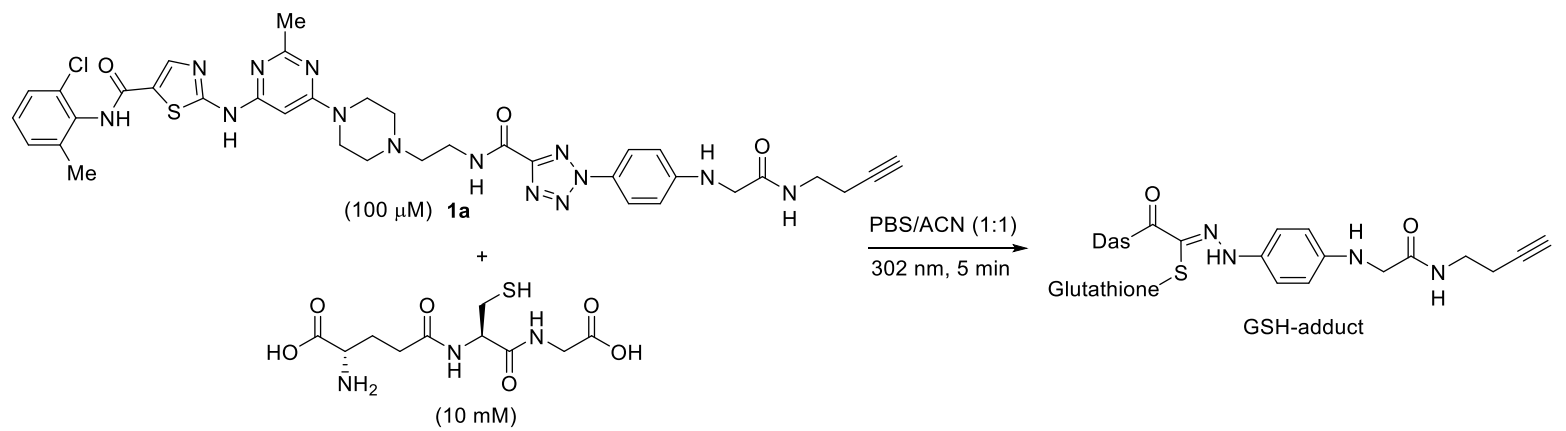



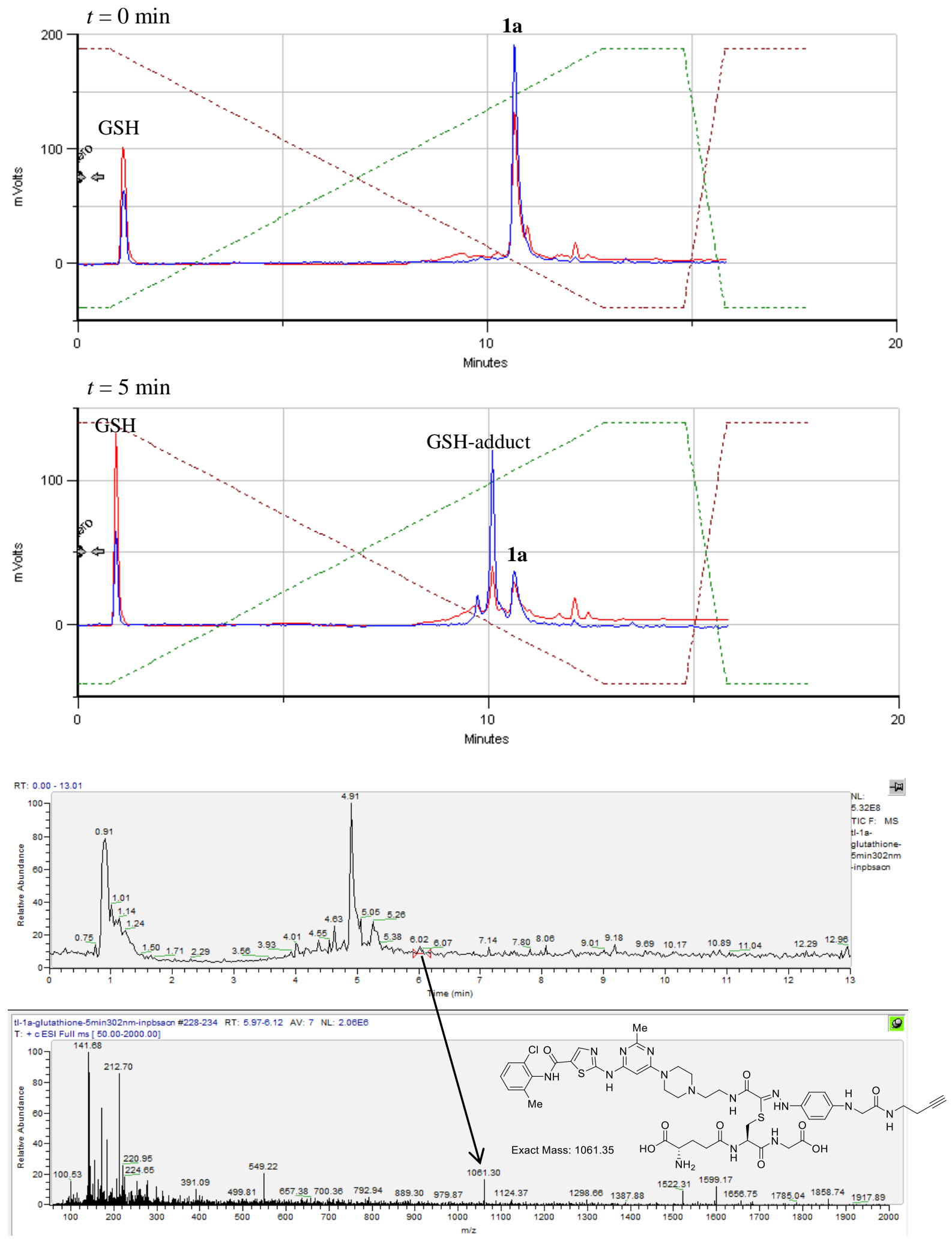
Figure S9. Model studies of the quenching reactions between $100 \mu \mathrm{M} \mathrm{S4}$ and $10 \mathrm{mM}$ (a) L-serine, (b) L-glutamic acid, (c) $\beta$-mercaptoethanol, and (d) glutathione in acetonitrile/PBS (1:1, $70 \mathrm{mM}$ $\left.\mathrm{Cl}^{-}, \mathrm{pH} 7.5\right)$ after 5-min $302 \mathrm{~nm}$ photoirradiation. (e) Quenching of probe $1 \mathbf{a}(100 \mu \mathrm{M})$ by $10 \mathrm{mM}$ glutathione in acetonitrile/PBS $\left(1: 1,70 \mathrm{mM} \mathrm{Cl}^{-}, \mathrm{pH} 7.5\right)$ after 5-min $302 \mathrm{~nm}$ photoirradiation. For HPLC chromatogram, red trace $=$ absorbance at $254 \mathrm{~nm}$; blue trace $=$ absorbance at $365 \mathrm{~nm}$. While L-serine and L-glutamic acid cannot compete effectively with the chloride quenching, $\beta$ mercaptoethanol and glutathione can form covalent adducts with the in situ generated carboxynitrile imine based on HPLC traces. However, the thiol-adduct masses were not detectable in (c) and (d), but detectable in (e), presumably due to differences in ionization potential of the adducts.

a) Diaryltetrazole S12 $(100 \mu \mathrm{M})$ without photoirradiation
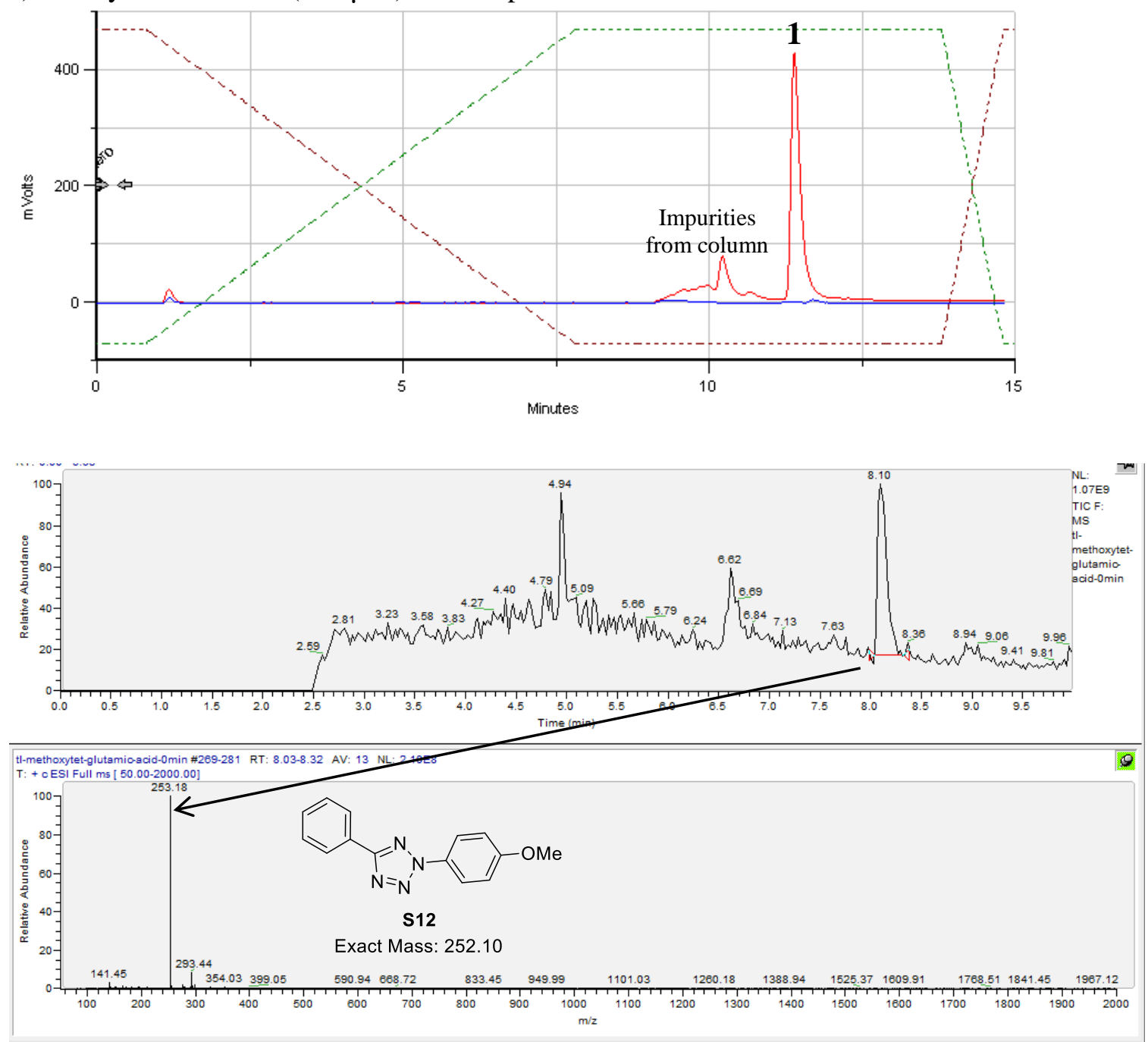
b) Diaryltetrazole $\mathbf{S 1 2}$ only (100 $\mu \mathrm{M})$ in PBS/ACN (1:1), irradiated at $302 \mathrm{~nm}$ for $5 \mathrm{~min}$
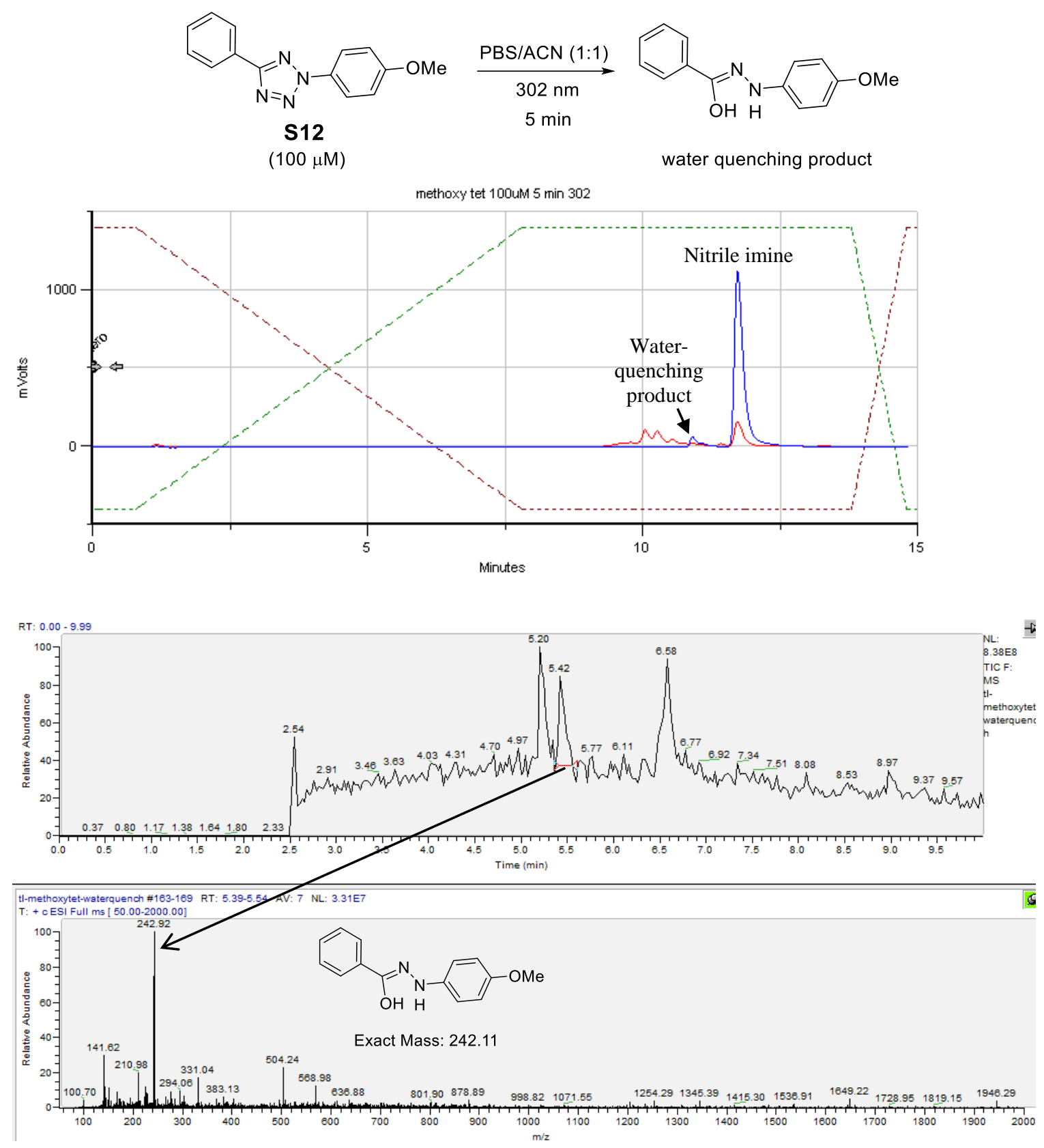

c) Diaryltetrazole S12 $(100 \mu \mathrm{M})+10 \mathrm{mM}$ glutamic acid in PBS/ACN (1:1), irradiated at $302 \mathrm{~nm}$ for $5 \mathrm{~min}$<smiles>COc1ccc(-n2nnc(-c3ccccc3)n2)cc1</smiles><smiles>COc1ccc(N(N=C(O)c2ccccc2)C(=O)CCC(N)C(=O)O)cc1</smiles>

glutamate quenching product<smiles>COc1ccc(NN=C(O)c2ccccc2)cc1</smiles>

water quenching product 

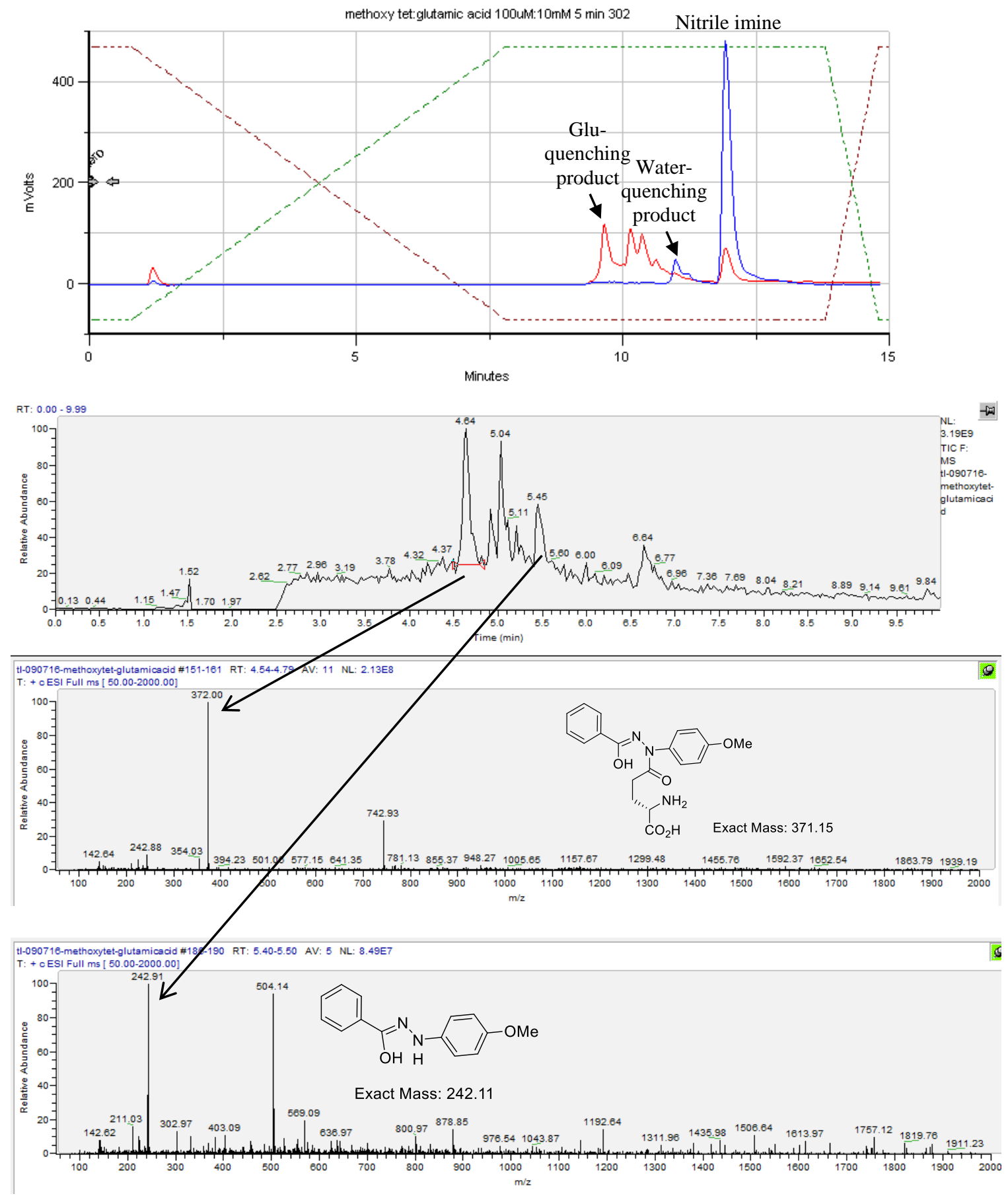

Figure S10. Model studies of the quenching reaction of $\mathbf{S 1 2}$ by glutamic acid in PBS/acetonitrile $(1: 1)$. 


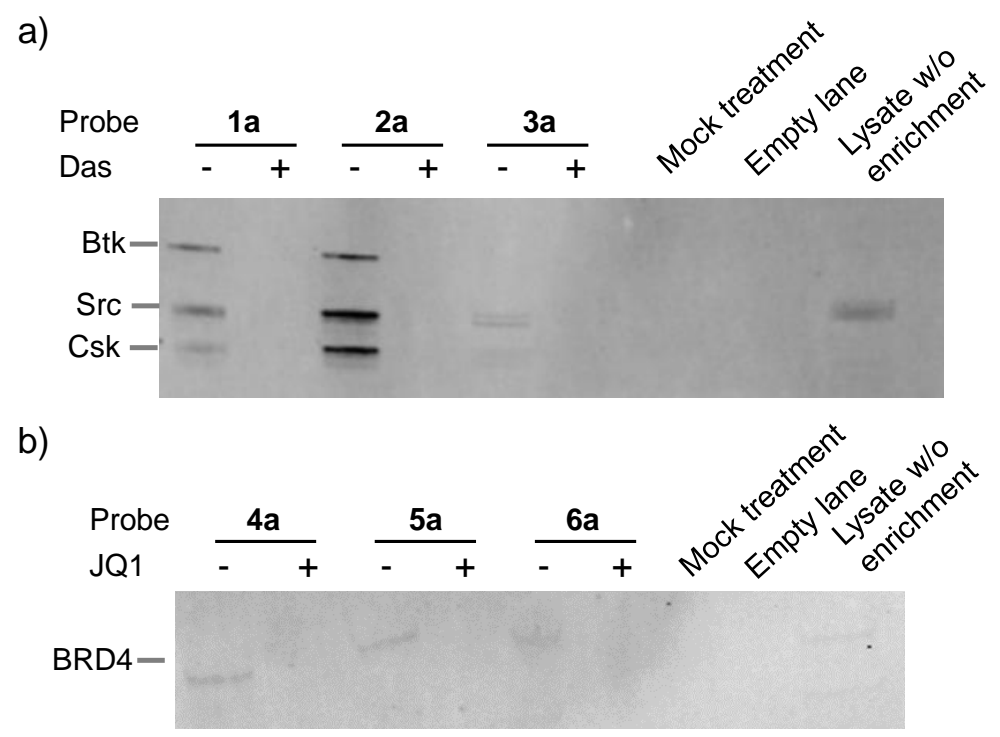

Figure S11. Western blot detection of the targets after the photoaffinity label-mediated crosslinking and subsequent pulldown. (a) Western blot of BTK, Src and Csk in the pull-downed samples using a mixture of anti-BTK, anti-Src, and anti-Csk antibodies followed by detection with an IR dye-conjugated secondary antibody. (b) Western blot of BRD4 in the pull-downed samples using an anti-BRD4 antibody followed by detection with an IR dye-conjugated secondary antibody. 
Table S3. Kinase targets captured by probes 1a and 2a and identified by LC-MS/MS.

\begin{tabular}{|l|l|l|c|c|c|}
\hline Accession & Gene ID & Description & $\begin{array}{c}\text { \# unique } \\
\text { peptides }\end{array}$ & $\begin{array}{c}\text { AUC: } \\
\text { enriched } \\
\text { by 1a }\end{array}$ & $\begin{array}{c}\text { AUC: } \\
\text { inhibited } \\
\text { by } \\
\text { Dasatinib }\end{array}$ \\
\hline Q06187 & BTK & Tyrosine-protein kinase BTK & 15 & $3.00 \mathrm{E}+06$ & N/D \\
\hline P07948 & LYN & Tyrosine-protein kinase Lyn & 5 & $1.30 \mathrm{E}+06$ & N/D \\
\hline P07947 & YES1 & Tyrosine-protein kinase Yes & 4 & $1.30 \mathrm{E}+06$ & N/D \\
\hline P41240 & CSK & Tyrosine-protein kinase CSK & 6 & $1.20 \mathrm{E}+06$ & N/D \\
\hline Q16539 & MAPK14 & Mitogen-activated protein kinase 14 & 4 & $1.20 \mathrm{E}+06$ & N/D \\
\hline Q53H12 & AGK & Acylglycerol kinase, mitochondrial & 3 & $4.40 \mathrm{E}+05$ & N/D \\
\hline
\end{tabular}

\begin{tabular}{|l|l|l|c|c|c|}
\hline Accession & Gene ID & Description & $\begin{array}{c}\text { \# unique } \\
\text { peptides }\end{array}$ & $\begin{array}{c}\text { AUC: } \\
\text { enriched } \\
\text { by 2a }\end{array}$ & $\begin{array}{c}\text { AUC: } \\
\text { inhibited } \\
\text { by } \\
\text { Dasatinib }\end{array}$ \\
\hline P00519 & ABL1 & Tyrosine-protein kinase ABL1 & 3 & $3.80 \mathrm{E}+05$ & N/D \\
\hline Q06187 & BTK & Tyrosine-protein kinase BTK & 15 & $2.30 \mathrm{E}+06$ & N/D \\
\hline P41240 & CSK & Tyrosine-protein kinase CSK & 6 & $1.30 \mathrm{E}+06$ & N/D \\
\hline P07948 & LYN & Tyrosine-protein kinase Lyn & 6 & $1.10 \mathrm{E}+06$ & N/D \\
\hline Q16539 & MAPK14 & Mitogen-activated protein kinase 14 & 3 & $1.20 \mathrm{E}+06$ & N/D \\
\hline & MAPKAPK2 & $\begin{array}{l}\text { MAP kinase-activated protein } \\
\text { kinase 2 }\end{array}$ & 2 & $4.70 \mathrm{E}+05$ & N/D \\
\hline O43353 & RIPK2 & $\begin{array}{l}\text { Receptor-interacting } \\
\text { serine/threonine-protein kinase 2 }\end{array}$ & 3 & $8.30 \mathrm{E}+05$ & N/D \\
\hline P07947 & YES1 & Tyrosine-protein kinase Yes & 8 & $2.90 \mathrm{E}+06$ & N/D \\
\hline
\end{tabular}

$\mathrm{N} / \mathrm{D}$, not detected. 
Table S4. Protein targets captured by probes $4 \mathbf{a}$ and $\mathbf{5 a}$ and identified by LC-MS/MS.

\begin{tabular}{|l|l|l|c|c|c|}
\hline Accession & Gene ID & Description & $\begin{array}{c}\# \\
\text { Unique } \\
\text { peptides }\end{array}$ & $\begin{array}{c}\text { AUC: } \\
\text { enriched by } \\
\text { 4a }\end{array}$ & $\begin{array}{c}\text { AUC: } \\
\text { inhibited } \\
\text { by JQ-1 }\end{array}$ \\
\hline P25440 & BRD2 & Bromodomain-containing protein 2 & 4 & $5.90 \mathrm{E}+05$ & N/D \\
\hline Q15059 & BRD3 & Bromodomain-containing protein 3 & 3 & $3.50 \mathrm{E}+05$ & N/D \\
\hline O60885 & BRD4 & Bromodomain-containing protein 4 & 3 & $6.00 \mathrm{E}+05$ & N/D \\
\hline Q08554 & DSC1 & Desmocollin-1 & 2 & $2.40 \mathrm{E}+05$ & N/D \\
\hline
\end{tabular}

\begin{tabular}{|l|l|l|c|c|c|}
\hline Accession & Gene ID & Description & $\begin{array}{c}\# \\
\text { Unique } \\
\text { peptides }\end{array}$ & $\begin{array}{c}\text { AUC: } \\
\text { enriched } \\
\text { by 5a }\end{array}$ & $\begin{array}{c}\text { AUC: } \\
\text { inhibited } \\
\text { by JQ-1 }\end{array}$ \\
\hline P25440 & BRD2 & Bromodomain-containing protein 2 & 7 & $9.60 \mathrm{E}+05$ & N/D \\
\hline Q15059 & BRD3 & Bromodomain-containing protein 3 & 3 & $3.10 \mathrm{E}+05$ & N/D \\
\hline O60885 & BRD4 & Bromodomain-containing protein 4 & 4 & $8.10 \mathrm{E}+05$ & N/D \\
\hline P04745 & AMY1A & Alpha-amylase 1 & 2 & $8.20 \mathrm{E}+05$ & N/D \\
\hline P19013 & KRT4 & Keratin, type II cytoskeletal 4 & 5 & $4.00 \mathrm{E}+05$ & N/D \\
\hline
\end{tabular}

$\mathrm{N} / \mathrm{D}$, not detected. 
Table S5. Comparison of kinases identified from this study with those reported in the literature. The common kinase targets identified by probes $\mathbf{1 a} / \mathbf{2 a}$ in the present study are colored in blue. N/D, not detected.

\begin{tabular}{|c|c|c|c|c|c|c|c|c|c|}
\hline \multirow{2}{*}{ Gene ID } & \multirow{2}{*}{$\begin{array}{c}\text { AUC: } \\
\text { enriched } \\
\text { by Das- } \\
\text { ACT (1a) }\end{array}$} & \multirow{2}{*}{$\begin{array}{c}\text { AUC: } \\
\text { enriched } \\
\text { by Das- } \\
\text { DA }(\mathbf{2 a})\end{array}$} & \multicolumn{2}{|c|}{ JACS $2012^{a}$} & \multirow{2}{*}{$\begin{array}{c}\text { J. } \\
\text { Proteo } \\
\text { mics } \\
2011^{b} \\
\\
\text { In } \\
\text { vitro }\end{array}$} & \multirow{2}{*}{$\begin{array}{c}\text { PNAS } \\
2007^{c} \\
\begin{array}{c}\text { Immob } \\
\text { ilized } \\
\text { Das }\end{array}\end{array}$} & \multirow{2}{*}{$\begin{array}{c}\text { Nat. } \\
\text { Chem. } \\
\text { Biol. } \\
2010^{d} \\
\text { Immob } \\
\text { ilized } \\
\text { Das }\end{array}$} & \multirow{2}{*}{$\begin{array}{c}\text { Blood } \\
2007^{e}\end{array}$} & \multirow{2}{*}{$\begin{array}{c}\text { Nat. } \\
\text { Biotech. } \\
2007^{f}\end{array}$} \\
\hline & & & $\underset{\text { vitro }}{\mathrm{In}}$ & $\begin{array}{l}\text { In } \\
\text { situ }\end{array}$ & & & & & \\
\hline ABL1 & N/D & $3.80 \mathrm{E}+05$ & & & & + & + & + & $\begin{array}{c}+ \text { (BCR- } \\
\text { ABL) }\end{array}$ \\
\hline AGK & $4.40 \mathrm{E}+05$ & N/D & + & + & & & & & \\
\hline BTK & $3.00 \mathrm{E}+06$ & $2.30 \mathrm{E}+06$ & + & - & & + & & + & + \\
\hline CSK & $1.20 \mathrm{E}+06$ & $1.30 \mathrm{E}+06$ & + & - & + & + & + & + & + \\
\hline LYN & $1.30 \mathrm{E}+06$ & $1.10 \mathrm{E}+06$ & + & - & & + & + & + & + \\
\hline MAPK14 & $1.20 \mathrm{E}+06$ & $1.20 \mathrm{E}+06$ & & & & & + & + & + \\
\hline MAPKAPK2 & N/D & $4.70 \mathrm{E}+05$ & + & - & & & & & \\
\hline RIPK2 & N/D & $8.30 \mathrm{E}+05$ & & & & & + & + & + \\
\hline YES1 & $1.30 \mathrm{E}+06$ & $2.90 \mathrm{E}+06$ & + & - & & + & + & + & + \\
\hline
\end{tabular}

a "Cell-based proteome profiling of potential Dasatinib targets by use of affinity-based probes" Shi, H.; et al. J. Am. Chem. Soc. 2012, 134, 3001-3014. This paper described the in vitro and in situ photo-cross-linking enabled target capture and identification in HEPG2 and K562 cells. Only one kinase, AGK2, was identified in situ.

$b$ "Dasatinib, Imatinib and staurosporine capture compounds-Complementary tools for the profiling of kinases by Capture Compound Mass Spectrometry (CCMS)" Fischer, J. J.; et al. J. Proteomics 2011, 75, 160-168. In vitro target capture from HEPG2 cell lysate using the Dasatinib/Imatinib-photo-cross-linker-biotin conjugates.

$c$ "The Btk tyrosine kinase is a major target of the Bcr-Abl inhibitor Dasatinib" Hantschel, O.; et al. Proc. Natl. Acad. Sci. U.S.A. 2007, 104(33), 13283-13288. The immobilized Dasatinib was used in target capture and identification in K562 cell lysate.

$d$ "A chemical and phosphoproteomic characterization of dasatinib action in lung cancer" $\mathrm{Li}, \mathrm{J}$.; et al. Nat. Chem. Biol. 2010, 6, 291-299. The immobilized Dasatinib was used in target capture in the H292, H441 and HCC827 cell lysates.

e "Quantitative chemical proteomics reveals mechanisms of action of clinical ABL kinase inhibitors" Bantscheff, M.; et al. Nat. Biotechnol. 2007, 25, 1035. An immobilized mixture of 
kinase inhibitors ("kinobeads") was used, together with pretreatment with a certain inhibitor (e.g. Das), in detecting the specific capture of kinase targets. The K562 and HeLa cell lysates were used in the in vitro capture.

$f$ "Chemical proteomic profiles of the BCR-ABL inhibitors imatinib, nilotinib, and Dasatinib reveal novel kinase and nonkinase targets" Rix, U.; et al. Blood 2007, 110, 4055-4063. The immobilized Dasatinib was used in target capture and identification in K562 and primary CML cell lysates.

Table S6. Comparison of protein targets from this study with those reported in the literature. The common protein targets identified by probes $\mathbf{4 a} / \mathbf{5} \mathbf{a}$ in the present study are colored in blue. N/D, not detected.

\begin{tabular}{|l|l|c|c|c|}
\hline Gene ID & Protein Name & $\begin{array}{c}\text { AUC: } \\
\text { enriched by } \\
\text { JQ-1-ACT } \\
(\mathbf{4 a})\end{array}$ & $\begin{array}{c}\text { AUC: } \\
\text { enriched by } \\
\text { JQ-1-DA (5a) }\end{array}$ & JACS 2014 $^{a}$ \\
\hline AMY1A & Alpha-amylase 1 & N/D & $8.20 \mathrm{E}+05$ & - \\
\hline BRD2 & Bromodomain-containing protein 2 & $5.90 \mathrm{E}+05$ & $9.60 \mathrm{E}+05$ & - \\
\hline BRD3 & Bromodomain-containing protein 3 & $3.50 \mathrm{E}+05$ & $3.10 \mathrm{E}+05$ & - \\
\hline BRD4 & Bromodomain-containing protein 4 & $6.00 \mathrm{E}+05$ & $8.10 \mathrm{E}+05$ & - \\
\hline DSC1 & Desmocollin-1 & $2.40 \mathrm{E}+05$ & N/D & - \\
\hline KRT4 & Keratin, type II cytoskeletal 4 & N/D & $4.00 \mathrm{E}+05$ & - \\
\hline
\end{tabular}

a "Minimalist cyclopropene-containing photo-cross-linkers suitable for live-cell imaging and affinity-based protein labeling" Li, Z.; et al. J. Am. Chem. Soc. 2014, 136, 9990-9998. A related BRD4 inhibitor (structure shown below), not JQ-1, was used in this study. None of BRD proteins showed up in their high-confidence target list after in situ target capture in HEPG2 cells and subsequent LC-MS/MS analysis.
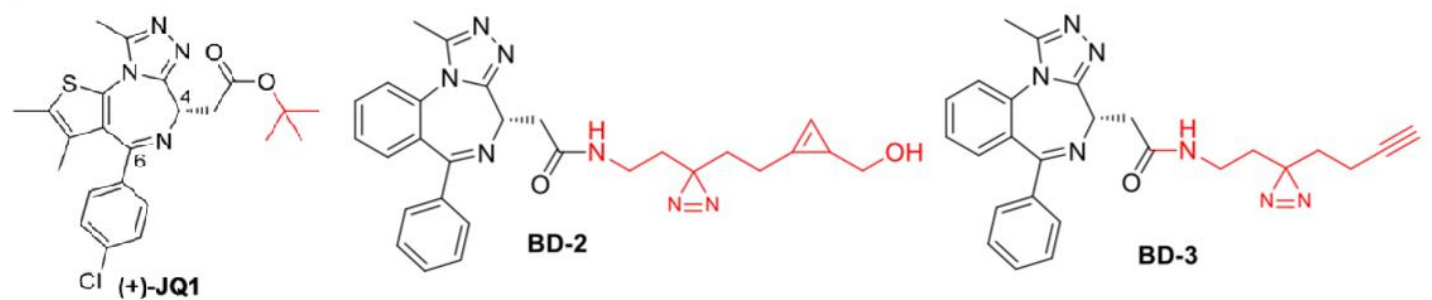


\section{General Information}

Recombinant human BTK protein used in the in-gel fluorescence experiments was purchased from Thermo Fisher (Cat. No. PR5442A). Recombinant human BTK (387-659) was used in the LC-MS based cross-linking experiments. Recombinant human BRD4 (44-168) protein used in the in-gel fluorescence and LC-MS studies was purchased from Active Motif (Cat. No. 31380). Solvents and chemicals were purchased from commercial sources and used directly without further purification. Flash chromatography was performed with SiliCycle P60 silica gel (40-63 $\mu \mathrm{m}, 60 \AA)$. ${ }^{1} \mathrm{H}$ NMR spectra were recorded with Varian Mercury-300, Inova-400 or $-500 \mathrm{MHz}$ spectrometers at University at Buffalo and Agilent 400-MR, Varian Inova 500 MHz, Varian VNMRS 500 MHz, Bruker Avance III $500 \mathrm{MHz}$ at Abbvie. Chemical shifts were reported in ppm using either TMS or deuterated solvents as internal standards (TMS, 0.00; $\mathrm{CDCl}_{3}, 7.26 ; \mathrm{CD}_{3} \mathrm{OD}, 3.31$; DMSO-d6, 2.50). Multiplicity was reported as follows: $\mathrm{s}=$ singlet, $\mathrm{d}=$ doublet, $\mathrm{t}=$ triplet, $\mathrm{q}=$ quartet, $\mathrm{p}=$ pentet, $\mathrm{m}=$ multiplet, brs = broad. ${ }^{13} \mathrm{C}$ NMR spectra were recorded at 75.4 or $126 \mathrm{MHz}$, and chemical shifts were reported in ppm using deuterated solvents as internal standards $\left(\mathrm{CDCl}_{3}, 77.0\right.$; DMSO-d6, 39.5; $\left.\mathrm{CD}_{3} \mathrm{OD}, 49.05\right)$. High resolution mass spectrometry was performed on a Bruker solariX XR Fourier transform ion cyclotron resonance mass spectrometer (FT-ICR-MS). In-gel fluorescence images were acquired by scanning SDS-PAGE gels with a BioRad PharosFX imager. Invitrogen PVDF membranes were used for western blots and scanned using Licor. For photoirradiation with a hand-held UV lamp, if not specified, $5 \mathrm{~min} 302-\mathrm{nm}$ photoirradiation was carried out for ACT probes, 10 min 365-nm photoirradiation was carried out for DA probes, and 10 min 302-nm photoirradiation was carried out for BP probes.

\section{Experimental Procedures and Characterization Data}

Scheme S1. Synthesis of the alkyne-functionalized ACT photo-affinity label
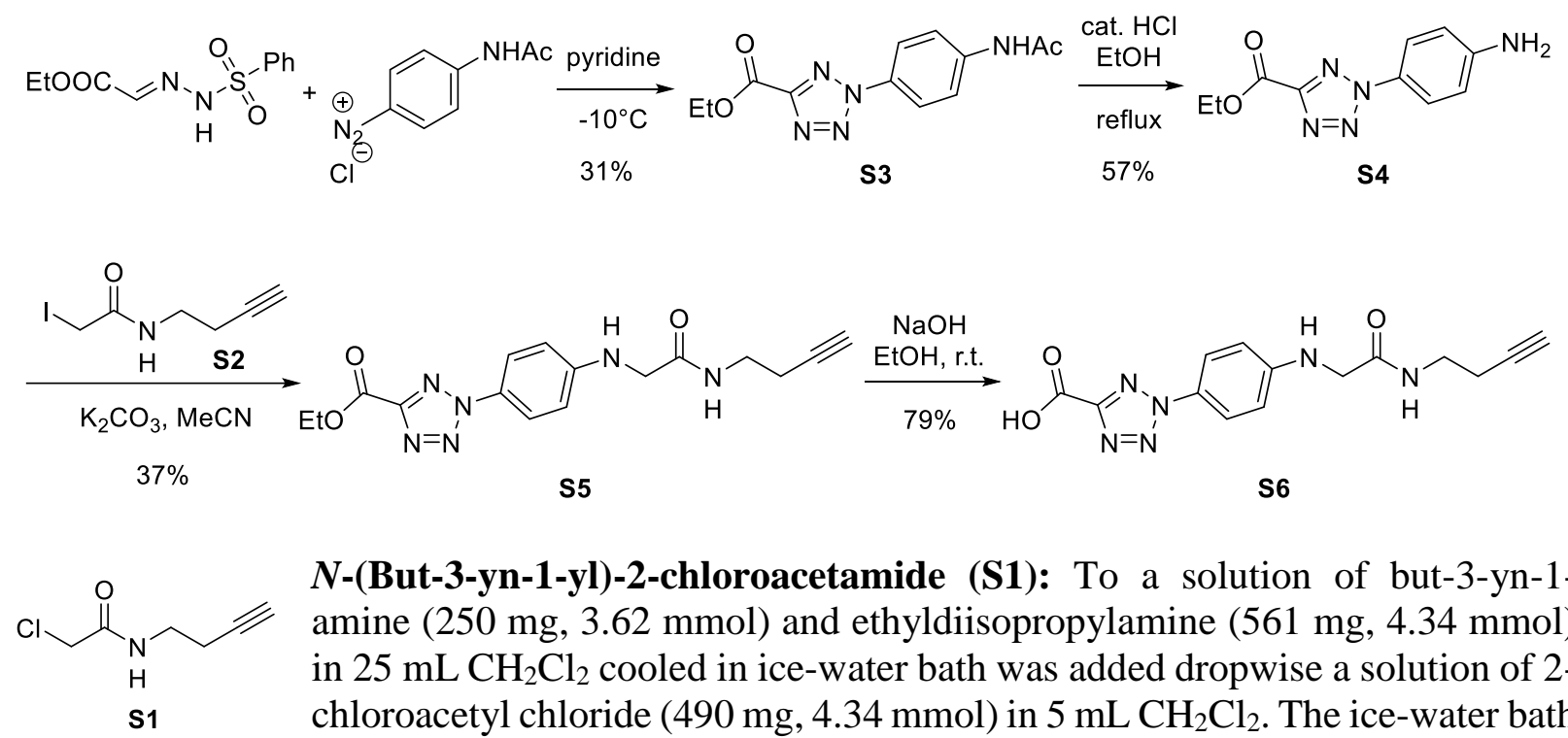

N-(But-3-yn-1-yl)-2-chloroacetamide (S1): To a solution of but-3-yn-1amine (250 mg, $3.62 \mathrm{mmol}$ ) and ethyldiisopropylamine (561 mg, $4.34 \mathrm{mmol}$ ) in $25 \mathrm{~mL} \mathrm{CH}_{2} \mathrm{Cl}_{2}$ cooled in ice-water bath was added dropwise a solution of 2chloroacetyl chloride (490 mg, $4.34 \mathrm{mmol}$ ) in $5 \mathrm{~mL} \mathrm{CH}_{2} \mathrm{Cl}_{2}$. The ice-water bath was removed, and the mixture was stirred at r.t. for $3 \mathrm{~h}$. Afterwards, additional $20 \mathrm{~mL} \mathrm{CH}_{2} \mathrm{Cl}_{2}$ was added, and the organic layer was washed successively with $20 \mathrm{~mL}$ saturated $\mathrm{NaHCO}_{3}, 20 \mathrm{~mL} 2 \mathrm{~N} \mathrm{HCl}$ and $20 \mathrm{~mL}$ brine, and dried over $\mathrm{MgSO}_{4}$. The solvent was then removed under reduced pressure to give the desired product as a brownish oil $(427 \mathrm{mg}, 81 \%$ yield $): \mathrm{R}_{f}=$ 
0.28 (hexanes/EtOAc = 2:1); ${ }^{1} \mathrm{H}$ NMR $\left(300 \mathrm{MHz}, \mathrm{CDCl}_{3}\right) \delta 7.08(\mathrm{~s}, 1 \mathrm{H}), 3.96(\mathrm{~s}, 2 \mathrm{H}), 3.35(\mathrm{q}, J$ $=6.1 \mathrm{~Hz}, 2 \mathrm{H}), 2.34(\mathrm{~s}, 2 \mathrm{H}), 1.98(\mathrm{~s}, 1 \mathrm{H}) ;{ }^{13} \mathrm{C} \mathrm{NMR}\left(75 \mathrm{MHz}, \mathrm{CDCl}_{3}\right) \delta 166.1,80.9,70.3,42.5$, $38.2,19.0$.

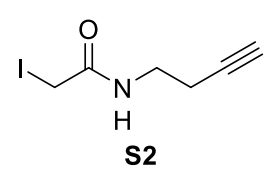

$N$-(But-3-yn-1-yl)-2-iodoacetamide (S2): To a solution of S1 (415 mg, 2.85 $\mathrm{mmol}$ ) in $15 \mathrm{~mL}$ acetone was added $\mathrm{NaI}$ (1.28 g, $8.55 \mathrm{mmol})$, and the mixture was refluxed for $4 \mathrm{~h}$. After the solvent was evaporated, the residue was redissolved in $30 \mathrm{~mL}$ EtOAc and $30 \mathrm{~mL}$ water. The organic layer was separated, washed successively with $20 \mathrm{~mL} 10 \% \mathrm{Na}_{2} \mathrm{~S}_{2} \mathrm{O}_{3}, 20 \mathrm{~mL} \mathrm{H}_{2} \mathrm{O}$ and $20 \mathrm{~mL}$ brine. After drying the solution over $\mathrm{MgSO}_{4}$, the solvent was removed with rotary evaporator to give the desired product as a light brown solid (471 mg, 70\% yield), which was used directly without further purification: ${ }^{1} \mathrm{H}$ NMR $\left(300 \mathrm{MHz}, \mathrm{CDCl}_{3}\right) \delta 6.72(\mathrm{~s}, 1 \mathrm{H}), 3.70(\mathrm{~s}, 2 \mathrm{H}), 3.40(\mathrm{q}, J=6.4 \mathrm{~Hz}, 2 \mathrm{H}), 2.41(\mathrm{td}, J=$ 6.5, 2.6 Hz, 2H), 2.04-2.01 (m, 1H); ${ }^{13} \mathrm{C} \mathrm{NMR}\left(75 \mathrm{MHz}, \mathrm{CDCl}_{3}\right) \delta 167.4,81.2,70.4,39.0,19.1$, 0.6 .

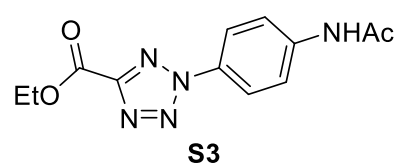

Ethyl 2-(4-acetamidophenyl)-2H-tetrazole-5-carboxylate (S3): A solution of $50 \%$ ethyl 2-oxoacetate in toluene $(3.042 \mathrm{~g}, 14.9 \mathrm{mmol})$ and benzenesulfonyl hydrazide $(1.72 \mathrm{~g}, 11.5 \mathrm{mmol})$ in $60 \mathrm{~mL}$ EtOH was stirred at r.t. for $1 \mathrm{~h}$. The solvent was removed under reduced pressure, and the residue was re-dissolved in $60 \mathrm{~mL}$ pyridine. Separately, to a suspension of $\mathrm{N}$-(4aminophenyl)acetamide (1.607 g, $10.7 \mathrm{mmol}$ ) and $4 \mathrm{~mL}$ concentrated $\mathrm{HCl}$ in $8 \mathrm{~mL} \mathrm{H}_{2} \mathrm{O}$ and 10 $\mathrm{mL}$ EtOH was added dropwise a solution of $\mathrm{NaNO}_{2}(0.775 \mathrm{~g}, 5.2 \mathrm{mmol})$ in $3 \mathrm{~mL} \mathrm{H}_{2} \mathrm{O}$ at $0{ }^{\circ} \mathrm{C}$. After 10-minute stirring, this solution was added dropwise to the previously prepared pyridine solution over $50 \mathrm{~min}$ at $-10^{\circ} \mathrm{C}$. The mixture was warmed up to r.t. over $2 \mathrm{~h}$ with stirring before $100 \mathrm{~mL} \mathrm{H} \mathrm{H}_{2} \mathrm{O}$ was added. The solution was extracted with $70 \mathrm{~mL} \mathrm{CH}_{2} \mathrm{Cl}_{2}$ three times, and the organic layers were collected, combined, washed successively with $3 \times 100 \mathrm{~mL} 2 \mathrm{~N} \mathrm{HCl}$ and $1 \times 70$ $\mathrm{mL}$ brine. After drying over $\mathrm{MgSO}_{4}$, the solvent was removed on a rotary evaporator. The dark brown oily residue was applied to a silica gel flash chromatography using hexanes/EtOAc $(1: 1 \rightarrow$ $1: 4)$ as the eluent to give the crude product as a dark yellow oil $(2.235 \mathrm{~g})$. The crude product was recrystallized twice from EtOH to give the titled compound as a yellow powder $(906 \mathrm{mg}, 31 \%$ yield): $\mathrm{R}_{f}=0.44$ (hexanes/EtOAc $\left.=1: 4\right) ;{ }^{1} \mathrm{H}$ NMR (300 MHz, DMSO- $\left.d_{6}\right) \delta 10.35(\mathrm{~s}, 1 \mathrm{H}), 8.07(\mathrm{~d}$, $J=9.1 \mathrm{~Hz}, 2 \mathrm{H}), 7.87(\mathrm{~d}, J=9.1 \mathrm{~Hz}, 2 \mathrm{H}), 4.46(\mathrm{q}, J=7.1 \mathrm{~Hz}, 2 \mathrm{H}), 2.10(\mathrm{~s}, 3 \mathrm{H}), 1.37(\mathrm{t}, J=7.1$ $\mathrm{Hz}, 3 \mathrm{H}) ;{ }^{13} \mathrm{C}$ NMR $\left(75 \mathrm{MHz}, \mathrm{DMSO}-d_{6}\right) \delta 168.9,157.2,157.1,141.5,130.6,121.1,119.6,62.3$, 24.1, 14.0; HRMS (ESI) $[\mathrm{M}+\mathrm{H}]^{+}$calcd for $\mathrm{C}_{12} \mathrm{H}_{14} \mathrm{~N}_{5} \mathrm{O}_{3} 276.1091[\mathrm{M}+\mathrm{H}]^{+}$, found 276.1094.

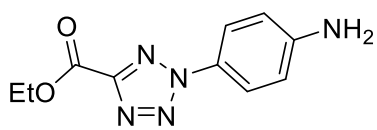

S4

Ethyl 2-(4-aminophenyl)-2H-tetrazole-5-carboxylate (S4): To a suspension acetamide derivative $\mathbf{S 3}(201 \mathrm{mg}, 0.73 \mathrm{mmol})$ in $5 \mathrm{~mL} \mathrm{EtOH}$ was added 10 drops of concentrated $\mathrm{HCl}$, and the mixture was refluxed until the starting material was consumed based on thin-layer chromatography. The mixture was cooled down to $-20{ }^{\circ} \mathrm{C}$, and the precipitate was collected with a glass filter, washed with cold $\mathrm{EtOH}$, and dried under vacuum to give the titled compound as an off-white powder ( $97 \mathrm{mg}, 57 \%$ yield): $\mathrm{R}_{f}=0.44$ (hexanes/EtOAc $=1: 1) ;{ }^{1} \mathrm{H}$ NMR $\left(500 \mathrm{MHz}, \mathrm{DMSO}-d_{6}\right) \delta 8.98(\mathrm{~s}, 2.6 \mathrm{H}), 8.07(\mathrm{~d}, J=8.9 \mathrm{~Hz}, 2 \mathrm{H}), 7.39(\mathrm{~d}, J=8.9$ $\mathrm{Hz}, 2 \mathrm{H}), 4.45(\mathrm{q}, J=7.1 \mathrm{~Hz}, 2 \mathrm{H}), 1.36(\mathrm{t}, J=7.1 \mathrm{~Hz}, 3 \mathrm{H}) ;{ }^{13} \mathrm{C}$ NMR $\left(125 \mathrm{MHz}, \mathrm{DMSO}-d_{6}\right) \delta$ 157.2, 157.1, 140.3, 131.5, 121.8, 121.3, 62.3, 14.0; HRMS (ESI) calcd for $\mathrm{C}_{10} \mathrm{H}_{12} \mathrm{~N}_{5} \mathrm{O}_{2} 234.0986$ $\left[\mathrm{M}+\mathrm{H}^{+}\right]$, found 234.0979 . 
<smiles>C#CCCNC(=O)CNc1ccc(-n2nnc(C(=O)OCC)n2)cc1</smiles>

S5

Ethyl 2-(4-((2-(but-3-yn-1-ylamino)-2-oxoethyl)amino) phenyl)-2H-tetrazole-5-carboxylate (S5): A mixture of aniline $\mathbf{S 4}$ (88 mg, $0.38 \mathrm{mmol})$, iodoacetamide $\mathbf{S 2}$ (90 $\mathrm{mg}$, $0.38 \mathrm{mmol}$ ) and $\mathrm{K}_{2} \mathrm{CO}_{3}(156 \mathrm{mg}, 1.13 \mathrm{mmol})$ in $3 \mathrm{~mL} \mathrm{MeCN}$ was refluxed for 2 days. The mixture was filtered through a layer of celite and the solvent was removed with a rotavapor.

The residue was applied to a silica gel flash chromatography using hexanes/EtOAc (1:10) as the eluent to give the desired product as an off-white powder $\left(48 \mathrm{mg}, 37 \%\right.$ yield): $\mathrm{R}_{f}=0.25$ (hexanes/EtOAc = 1:5); ${ }^{1} \mathrm{H}$ NMR $\left(500 \mathrm{MHz}, \mathrm{CDCl}_{3}\right) \delta 8.01(\mathrm{~d}, J=9.0 \mathrm{~Hz}, 2 \mathrm{H}), 6.74(\mathrm{~d}, J=9.0$ $\mathrm{Hz}, 2 \mathrm{H}), 6.71(\mathrm{~s}, 1 \mathrm{H}), 4.77(\mathrm{~s}, 1 \mathrm{H}), 4.56(\mathrm{q}, J=7.1 \mathrm{~Hz}, 2 \mathrm{H}), 3.90(\mathrm{~d}, J=3.7 \mathrm{~Hz}, 2 \mathrm{H}), 3.47(\mathrm{q}, J=$ $6.3 \mathrm{~Hz}, 2 \mathrm{H}), 2.42(\mathrm{td}, J=6.4,2.6 \mathrm{~Hz}, 2 \mathrm{H}), 1.91(\mathrm{t}, J=2.6 \mathrm{~Hz}, 1 \mathrm{H}), 1.48(\mathrm{t}, J=7.1 \mathrm{~Hz}, 3 \mathrm{H}) ;{ }^{13} \mathrm{C}$ NMR $\left(75 \mathrm{MHz}, \mathrm{DMSO}-d_{6}\right) \delta 169.5,157.4,156.7,150.5,125.4,121.6,112.4,82.1,72.2,62.1$, 46.3, 37.7, 18.7, 14.0; HRMS (ESI) calcd for $\mathrm{C}_{16} \mathrm{H}_{19} \mathrm{~N}_{6} \mathrm{O}_{3} 343.1513\left[\mathrm{M}+\mathrm{H}^{+}\right]$, found: 343.1514 .<smiles>C#CCCNC(=O)CNc1ccc(-n2nnc(C(=O)O)n2)cc1</smiles>

s6
2-(4-((2-(But-3-yn-1-ylamino)-2-oxoethyl)amino) phenyl)2H-tetrazole-5-carboxylic acid (S6): To a solution of tetrazole carboxylate $\mathbf{S 5}(37 \mathrm{mg}, 0.11 \mathrm{mmol})$ in $1 \mathrm{~mL} \mathrm{EtOH}$ at r.t. was added $2 \mathrm{~mL} 2 \mathrm{~N} \mathrm{NaOH}$, and the mixture was stirred at r.t. until the starting material was completely consumed based on thin layer chromatography. The solution was added $5 \mathrm{~mL}$ EtOAc and then acidified. The precipitate that appeared was collected with a glass filter, washed with water, and dried under vacuum to give the titled compound as an off-white powder (27 mg, 79\% yield): ${ }^{1} \mathrm{H}$ NMR (300 MHz, DMSO- $\left.d_{6}\right) \delta 8.16(\mathrm{t}, J=5.8 \mathrm{~Hz}, 1 \mathrm{H}), 7.82(\mathrm{~d}, J=9.0$ $\mathrm{Hz}, 2 \mathrm{H}), 6.74(\mathrm{~d}, J=9.1 \mathrm{~Hz}, 2 \mathrm{H}), 3.74(\mathrm{~s}, 2 \mathrm{H}), 3.22(\mathrm{q}, J=7.0 \mathrm{~Hz}, 2 \mathrm{H}), 2.84(\mathrm{t}, J=2.6 \mathrm{~Hz}, 1 \mathrm{H})$, $2.30(\mathrm{td}, J=7.1,2.7 \mathrm{~Hz}, 2 \mathrm{H}) ;{ }^{13} \mathrm{C}$ NMR $\left(125 \mathrm{MHz}, \mathrm{DMSO}-d_{6}\right) \delta 169.6,158.8,157.6,150.4,125.6$, 121.5, 112.4, 82.1, 72.1, 46.3, 37.7, 18.7; HRMS (ESI) calcd for $\mathrm{C}_{14} \mathrm{H}_{15} \mathrm{~N}_{6} \mathrm{O}_{3} 315.1200\left[\mathrm{M}+\mathrm{H}^{+}\right]$, found: 315.1202 .

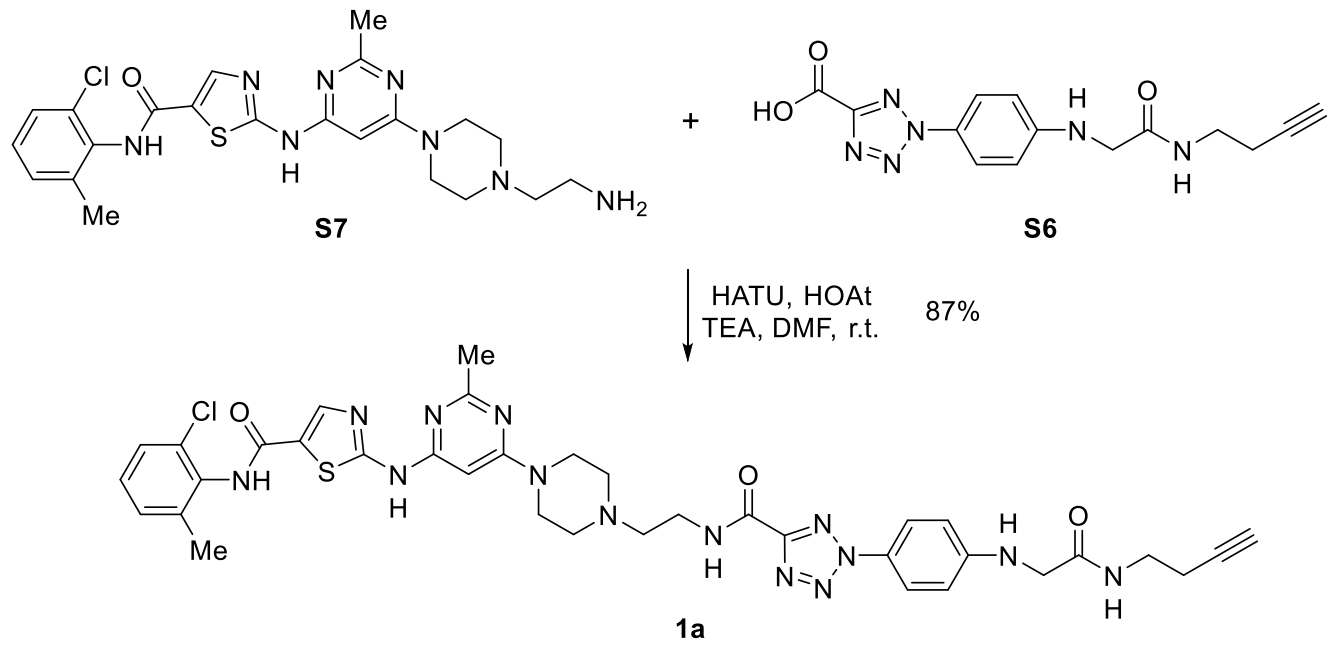

Synthesis of 1a: A solution of dasatinib amine.3TFA salt $\mathbf{S 7}(15.0 \mathrm{mg}, 0.018 \mathrm{mmol})$, tetrazole carboxylic acid S6 (6.8 mg, $0.022 \mathrm{mmol})$, HATU $(8.3 \mathrm{mg}, 0.022 \mathrm{mmol})$, 3-hydroxytriazolo[4,5b]pyridine (HOAt; $3.0 \mathrm{mg}, 0.022 \mathrm{mmol})$, and triethylamine $(10.6 \mu \mathrm{L}, 0.076 \mathrm{mmol})$ in $150 \mu \mathrm{L} \mathrm{DMF}$ was stirred at r.t. overnight. The reaction mixture was applied to a medium-pressure silica gel flash chromatography system equipped with an automatic fraction collector running the $\mathrm{MeOH} / \mathrm{CH}_{2} \mathrm{Cl}_{2}$ 
$(2: 98 \rightarrow 20: 80)$ eluent gradient. The suitable fractions were pooled and evaporated under reduced pressure. The residue was re-dissolved in $3 \mathrm{~mL} \mathrm{MeCN}$ and $3 \mathrm{~mL} \mathrm{H}_{2} \mathrm{O}$ containing $0.5 \% \mathrm{TFA}$, and the solution was lyophilized to dryness to give the titled compound as a white powder $(16.0 \mathrm{mg}$, $87 \%$ yield): $\mathrm{R}_{f}=0.63\left(\mathrm{MeOH} / \mathrm{CH}_{2} \mathrm{Cl}_{2}=1: 5\right) ;{ }^{1} \mathrm{H}-\mathrm{NMR}\left(500 \mathrm{MHz}, \mathrm{DMSO}-d_{6}\right) \delta 11.46(\mathrm{~s}, 0.7 \mathrm{H})$, $9.87(\mathrm{~s}, 0.8 \mathrm{H}), 8.97(\mathrm{t}, J=5.5 \mathrm{~Hz}, 0.6 \mathrm{H}), 8.22(\mathrm{~s}, 1 \mathrm{H}), 8.15(\mathrm{t}, J=5.6 \mathrm{~Hz}, 0.7 \mathrm{H}), 7.82(\mathrm{~d}, J=8.8$ $\mathrm{Hz}, 2 \mathrm{H}), 7.40(\mathrm{~d}, J=7.4 \mathrm{~Hz}, 1 \mathrm{H}), 7.32-7.22(\mathrm{~m}, 2 \mathrm{H}), 6.78-6.71(\mathrm{~m}, 3 \mathrm{H}), 6.06(\mathrm{~s}, 1 \mathrm{H}), 3.74(\mathrm{~d}$, $J=5.4 \mathrm{~Hz}, 2 \mathrm{H}), 3.57-3.44(\mathrm{~m}, 6 \mathrm{H}), 3.34-3.28(\mathrm{~m}, 2 \mathrm{H}), 3.26-3.18(\mathrm{~m}, 2 \mathrm{H}), 2.98$ (brs, $1 \mathrm{H})$, $2.83(\mathrm{~s}, 1 \mathrm{H}), 2.57(\mathrm{t}, J=6.6 \mathrm{~Hz}, 2 \mathrm{H}), 2.55-2.51(\mathrm{~m}$, under the DMSO signal), $2.41(\mathrm{~s}, 3 \mathrm{H}), 2.30$ $(\mathrm{td}, J=6.8,2.1 \mathrm{~Hz}, 2 \mathrm{H}), 2.24(\mathrm{~s}, 3 \mathrm{H})$; HRMS (ESI) calcd for $\mathrm{C}_{36} \mathrm{H}_{40} \mathrm{ClN}_{14} \mathrm{O}_{3} \mathrm{~S} 783.2812\left[\mathrm{M}+\mathrm{H}^{+}\right]$, found 783.2817 . The product purity was also verified by analytical HPLC as shown below.

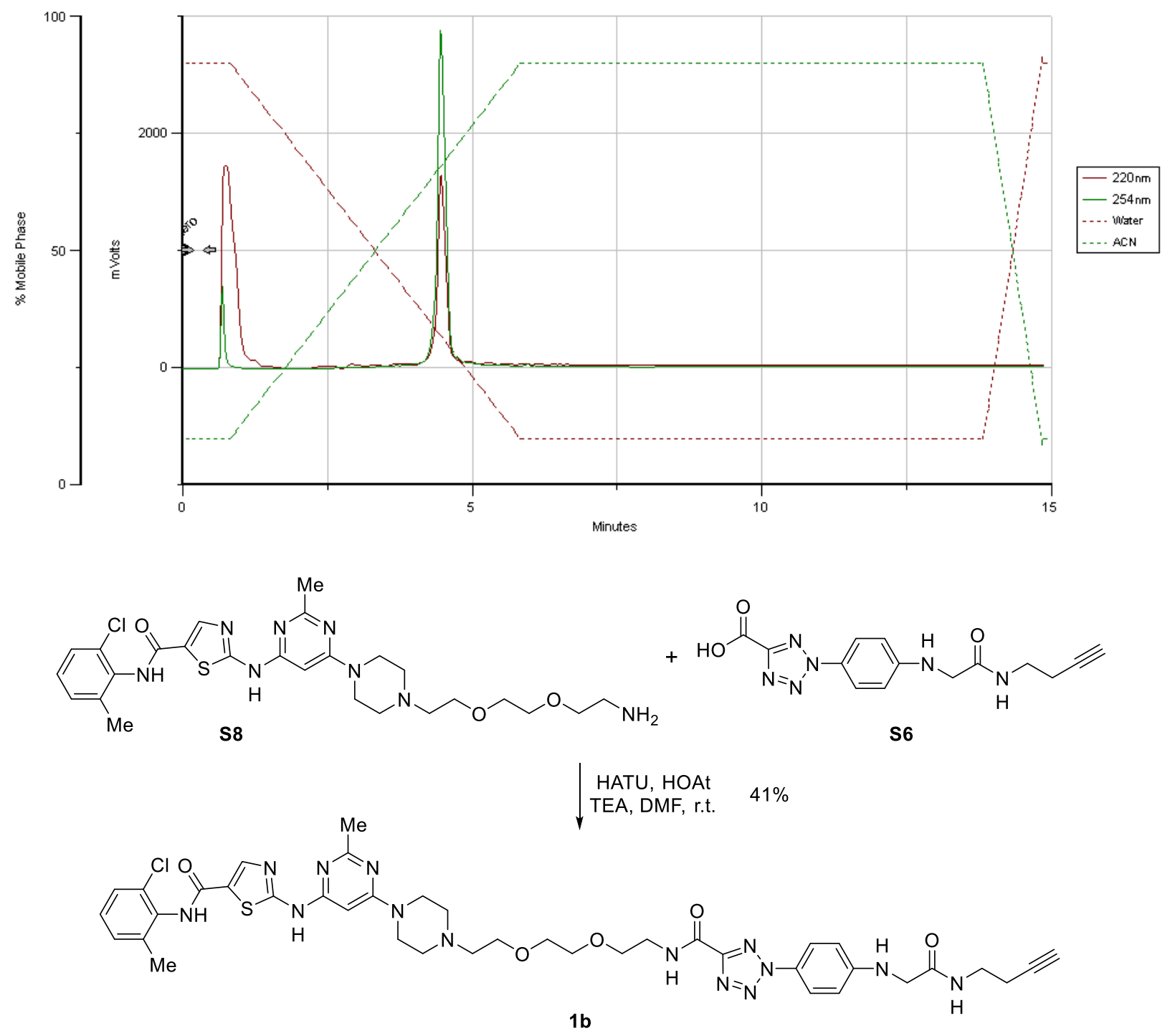

Synthesis of 1b: A solution of dasatinib amine.3TFA salt $\mathbf{S 8}(15.0 \mathrm{mg}, 0.016 \mathrm{mmol})$, tetrazole carboxylic acid S6 (6.2 mg, $0.020 \mathrm{mmol})$, HATU (7.5 mg, $0.020 \mathrm{mmol})$, HOAt (2.7 mg, 0.020 $\mathrm{mmol})$, and triethylamine $(9.6 \mu \mathrm{L}, 0.069 \mathrm{mmol})$ in $150 \mu \mathrm{L}$ DMF was stirred at r.t. overnight. The reaction mixture was applied to a medium-pressure silica gel flash chromatography system equipped with an automatic fraction collector running the $\mathrm{MeOH} / \mathrm{CH}_{2} \mathrm{Cl}_{2}(2: 98 \rightarrow 20: 80)$ eluent 
gradient. The suitable fractions were pooled and evaporated under reduced pressure. The residue was re-dissolved in $3 \mathrm{~mL} \mathrm{MeCN}$ and $3 \mathrm{~mL} \mathrm{H}_{2} \mathrm{O}$ containing 0.5\% TFA, and the solution was lyophilized to dryness to give the titled compound as a white powder $\left(7.4 \mathrm{mg}, 41 \%\right.$ yield): $\mathrm{R}_{f}=$ $0.61\left(\mathrm{MeOH} / \mathrm{CH}_{2} \mathrm{Cl}_{2}=1: 5\right) ;{ }^{1} \mathrm{H}-\mathrm{NMR}\left(500 \mathrm{MHz}, \mathrm{DMSO}-d_{6}\right) \delta 11.45(\mathrm{~s}, 0.8 \mathrm{H}), 9.87(\mathrm{~s}, 1 \mathrm{H}), 8.98$ (s, $1 \mathrm{H}), 8.22(\mathrm{~s}, 1 \mathrm{H}), 8.15(\mathrm{~s}, 1 \mathrm{H}), 7.82(\mathrm{~d}, J=8.3 \mathrm{~Hz}, 2 \mathrm{H}), 7.40(\mathrm{~d}, J=7.2 \mathrm{~Hz}, 1 \mathrm{H}), 7.32-7.22$ $(\mathrm{m}, 2 \mathrm{H}), 6.77-6.70(\mathrm{~m}, 3 \mathrm{H}), 6.04(\mathrm{~s}, 1 \mathrm{H}), 4.09(\mathrm{~d}, J=4.0 \mathrm{~Hz}, 1 \mathrm{H}), 3.73(\mathrm{~d}, J=5.2 \mathrm{~Hz}, 2 \mathrm{H}), 3.62$ $-3.43(\mathrm{~m}, 18 \mathrm{H}), 3.27-3.12(\mathrm{~m}, 7 \mathrm{H}), 2.82(\mathrm{~s}, 0.8 \mathrm{H}), 2.49-2.44(\mathrm{~m}$, overlapping with the DMSO signal), $2.40(\mathrm{~s}, 3 \mathrm{H}), 2.30(\mathrm{t}, J=5.5 \mathrm{~Hz}, 2 \mathrm{H}), 2.24(\mathrm{~s}, 3 \mathrm{H})$; HRMS (ESI) calcd for $\mathrm{C}_{40} \mathrm{H}_{48} \mathrm{ClN}_{14} \mathrm{O}_{5} \mathrm{~S}$ $871.3336[\mathrm{M}+\mathrm{H}]^{+}$, found 871.3358 . The product purity was also verified by analytical HPLC as shown below.

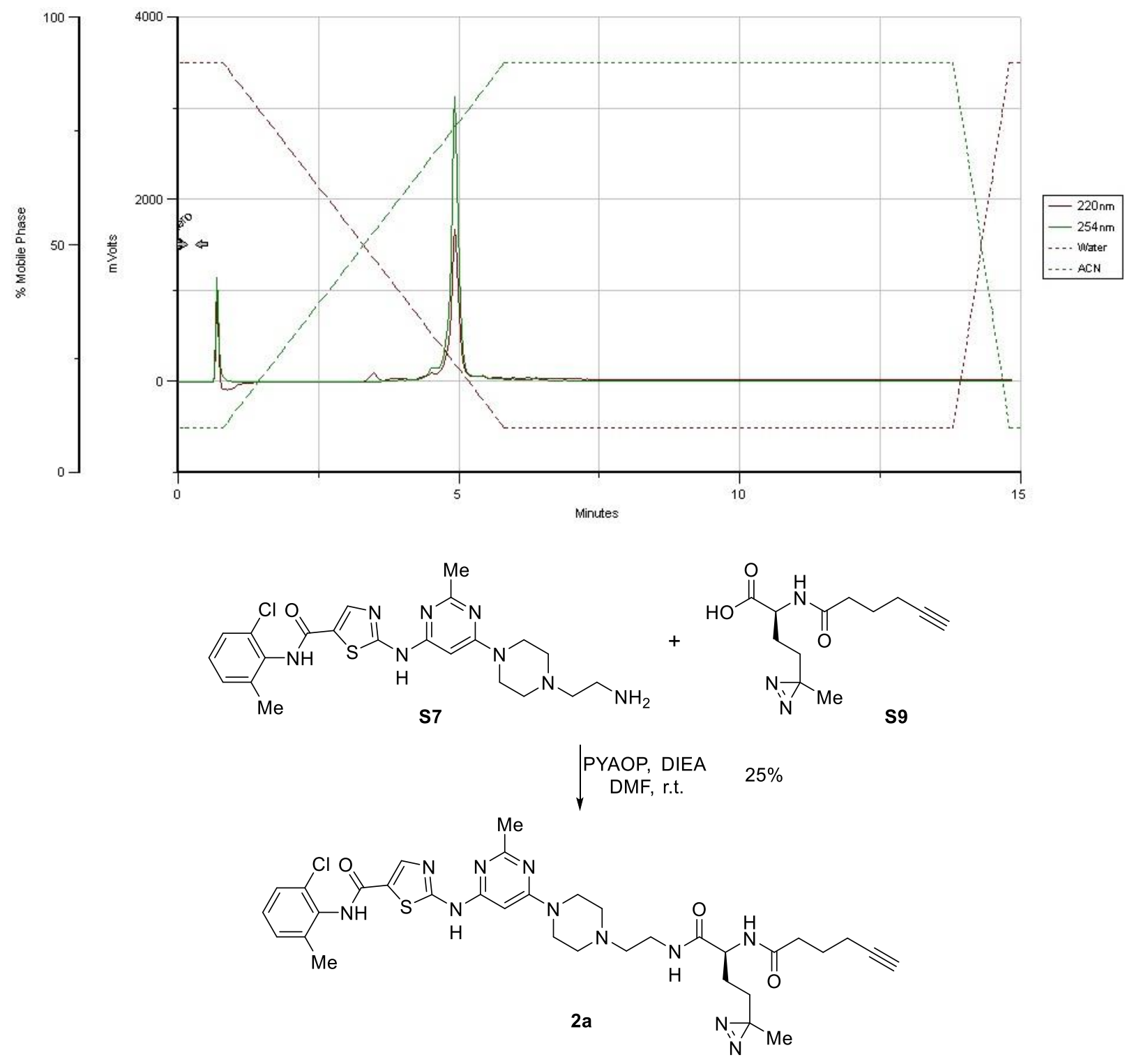

Synthesis of 2a: A solution of dasatinib amine.3TFA salt $\mathbf{S 7}(27.1 \mathrm{mg}, 0.033 \mathrm{mmol})$, diazirine acid S9 $(8.2 \mathrm{mg}, 0.033 \mathrm{mmol})$, (7-azabenzotriazol-1-yloxy)tripyrrolidinophosphonium hexafluorophosphate (PyAOP; $17.01 \mathrm{mg}, 0.033 \mathrm{mmol})$ and ethyldiisopropylamine $(0.023 \mathrm{~mL}, 0.131$ $\mathrm{mmol}$ ) were combined in DMF ( $3 \mathrm{~mL}$ ) and stirred for $2 \mathrm{~h}$ at r.t. The crude reaction mix was diluted 
with $90 \% \mathrm{DMSO} /$ water to $4 \mathrm{~mL}$ and purified on preparative HPLC. The eluents were A: $0.1 \%$ TFA-water; B: acetonitrile. $0-5 \mathrm{~min}$ isocratic followed by $1 \%$ increase in acetonitrile per min gradient. The appropriate fractions were collected and lyophilized to dryness to give the titled compound (7.7 mg, 25\% yield): ${ }^{1} \mathrm{H}-\mathrm{NMR}\left(500 \mathrm{MHz}, \mathrm{DMSO}-d_{6}\right) \delta 11.64(\mathrm{~s}, 1 \mathrm{H}), 9.91(\mathrm{~s}, 1 \mathrm{H})$, 9.67 (brs, $1 \mathrm{H}), 8.24(\mathrm{~s}, 1 \mathrm{H}), 8.21(\mathrm{t}, J=5.7 \mathrm{~Hz}, 1 \mathrm{H}), 8.10(\mathrm{~d}, J=7.3 \mathrm{~Hz}, 1 \mathrm{H}), 7.40$ (dd, $J=7.7$, $1.4 \mathrm{~Hz}, 1 \mathrm{H}), 7.32-7.23(\mathrm{~m}, 2 \mathrm{H}), 6.15(\mathrm{~s}, 1 \mathrm{H}), 4.36$ (brs, 1.6H), $4.12-4.04(\mathrm{~m}, 1 \mathrm{H}), 3.60$ (m, under the water signal), $3.29-3.06$ (m, under the water signal), $3.01(\mathrm{td}, J=6.6,3.9 \mathrm{~Hz}, 1 \mathrm{H}), 2.79$ $(\mathrm{t}, J=2.6 \mathrm{~Hz}, 1 \mathrm{H}), 2.45(\mathrm{~s}, 3 \mathrm{H}), 2.26-2.20(\mathrm{~m}, 5 \mathrm{H}), 2.15(\mathrm{td}, J=7.2,2.6 \mathrm{~Hz}, 2 \mathrm{H}), 1.76-1.71$ $(\mathrm{m}, 1 \mathrm{H}), 1.69-1.62(\mathrm{~m}, 2 \mathrm{H}), 1.54-1.22(\mathrm{~m}, 4 \mathrm{H}), 0.99(\mathrm{~s}, 3 \mathrm{H})$; HRMS (ESI) calcd for $\mathrm{C}_{34} \mathrm{H}_{42} \mathrm{ClN}_{11} \mathrm{O}_{3} \mathrm{~S} 719.2960\left[\mathrm{M}+\mathrm{H}^{+}\right]$, found 720.2950 .

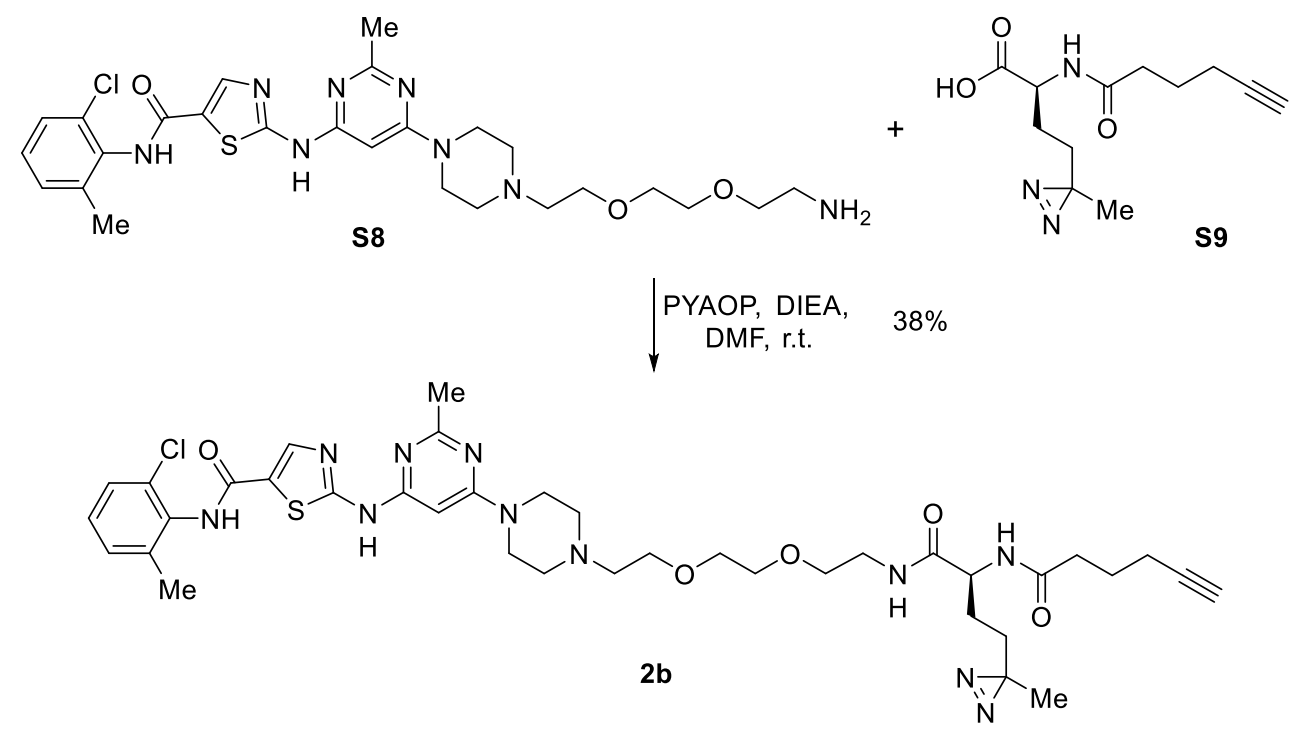

Synthesis of 2b: A solution of dasatinib amine.3TFA salt $\mathbf{S 8}(10 \mathrm{mg}, 10.90 \mu \mathrm{mol})$, diazirine acid S9 $(7.3 \mathrm{mg}, 0.029 \mathrm{mmol})$, PyAOP $(15.15 \mathrm{mg}, 0.029 \mathrm{mmol})$ and ethyldiisopropylamine $(0.020 \mathrm{~mL}$, $0.116 \mathrm{mmol}$ ) were combined in DMF $(3 \mathrm{~mL})$ and stirred for $2 \mathrm{~h}$ at r.t. The crude reaction mix was diluted with $90 \% \mathrm{DMSO} /$ water to $4 \mathrm{~mL}$ and purified preparative HPLC. The eluents were A: $0.1 \%$ TFA-water; B: acetonitrile. 0-5 min isocratic; $1 \% / \mathrm{min}$ acetonitrile gradient. The appropriate fractions were collected and lyophilized to dryness to give the titled compound $(8.8 \mathrm{mg}, 38 \%$ yield): ${ }^{1} \mathrm{H}$ NMR (500 MHz, DMSO- $\left.d_{6}\right) \delta 11.64(\mathrm{~s}, 1 \mathrm{H}), 9.91(\mathrm{~s}, 1 \mathrm{H}), 9.79$ (brs, $\left.1 \mathrm{H}\right), 8.24(\mathrm{~s}, 1 \mathrm{H})$, $7.96(\mathrm{~d}, J=8.0 \mathrm{~Hz}, 1 \mathrm{H}), 7.92(\mathrm{t}, J=5.7 \mathrm{~Hz}, 1 \mathrm{H}), 7.40(\mathrm{dd}, J=7.7,1.4 \mathrm{~Hz}, 1 \mathrm{H}), 7.32-7.24(\mathrm{~m}$, 2H), $6.15(\mathrm{~s}, 1 \mathrm{H}), 4.35(\mathrm{~d}, J=12.5 \mathrm{~Hz}, 2 \mathrm{H}), 4.15(\mathrm{td}, J=8.2,5.2 \mathrm{~Hz}, 1 \mathrm{H}), 3.81-3.75(\mathrm{~m}, 2 \mathrm{H})$, $3.64-3.54(\mathrm{~m}$, under the water signal), $3.32-3.07(\mathrm{~m}$, under the water signal), $3.04-2.98(\mathrm{~m}$, $1 \mathrm{H}), 2.78(\mathrm{t}, J=2.7 \mathrm{~Hz}, 1 \mathrm{H}), 2.45(\mathrm{~s}, 3 \mathrm{H}), 2.24(\mathrm{~s}, 3 \mathrm{H}), 2.20(\mathrm{td}, J=7.2,1.3 \mathrm{~Hz}, 2 \mathrm{H}), 2.13(\mathrm{td}, J$ = 7.2, $2.7 \mathrm{~Hz}, 2 \mathrm{H}), 1.76-1.71(\mathrm{~m}, 1 \mathrm{H}), 1.69-1.60(\mathrm{~m}, 2 \mathrm{H}), 1.52-1.21(\mathrm{~m}, 5 \mathrm{H}), 0.97(\mathrm{~s}, 3 \mathrm{H})$; HRMS (ESI) calcd for $\mathrm{C}_{38} \mathrm{H}_{51} \mathrm{ClN}_{11} \mathrm{O}_{5} \mathrm{~S} 808.3485\left[\mathrm{M}+\mathrm{H}^{+}\right]$, found 808.3477. 

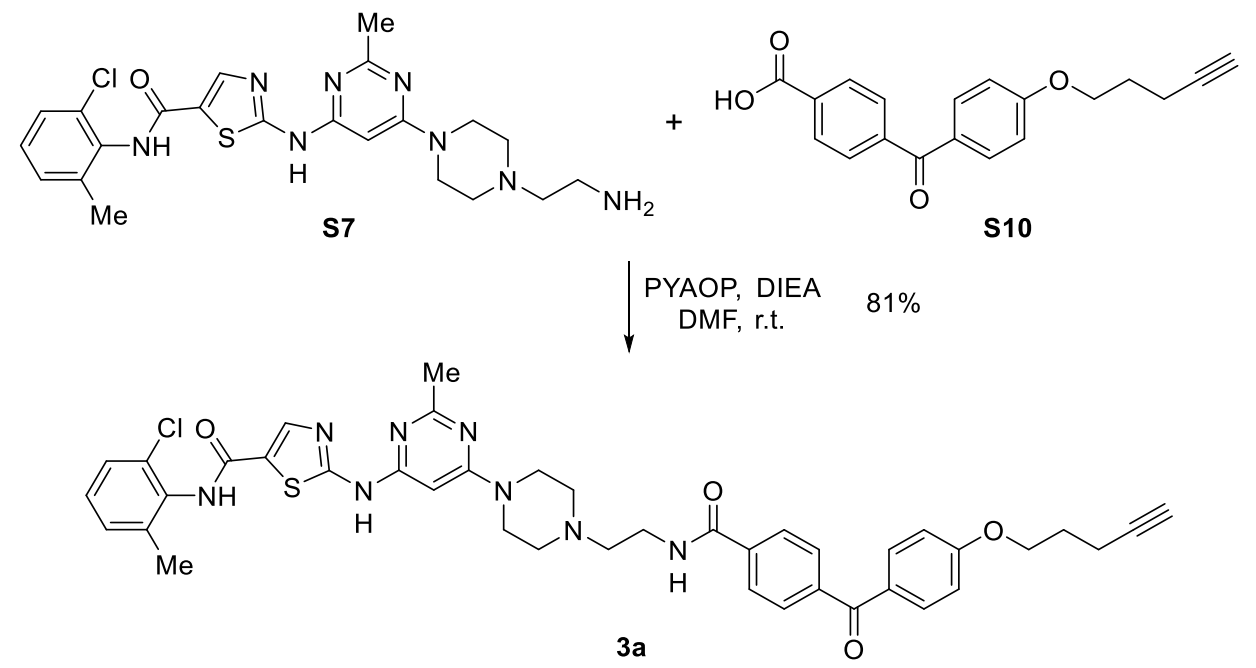

Synthesis of 3a: A solution of dasatinib amine.3TFA salt $\mathbf{S 7}$ (30 $\mathrm{mg}, 0.036 \mathrm{mmol}$ ), benzoic acid S10 (12.27 mg, $0.040 \mathrm{mmol})$, PyAOP (20.75 $\mathrm{mg}, 0.040 \mathrm{mmol})$ and ethyldiisopropylamine $(0.025$ $\mathrm{mL}, 0.145 \mathrm{mmol})$ were combined in DMF $(3 \mathrm{~mL})$ and stirred for $2 \mathrm{~h}$ at r.t. The crude reaction mix was diluted with $90 \% \mathrm{DMSO} /$ water to $4 \mathrm{~mL}$ and purified preparative HPLC. The eluents were A: $0.1 \%$ TFA-water; B: acetonitrile. $0-5 \mathrm{~min}$ isocratic; $1 \% / \mathrm{min}$ acetonitrile gradient after that point. The appropriate fractions were collected and lyophilized to dryness to give the titled compound (29.3 mg, 81\% yield): ${ }^{1} \mathrm{H}$ NMR (500 MHz, DMSO- $d_{6}$ ) $\delta 11.66$ (brs, $1 \mathrm{H}$ ), 9.92 (s, brs, $2 \mathrm{H}$ ), 8.96 (t, $J=5.6 \mathrm{~Hz}, 1 \mathrm{H}), 8.24(\mathrm{~s}, 1 \mathrm{H}), 8.03(\mathrm{~d}, J=8.5 \mathrm{~Hz}, 2 \mathrm{H}), 7.80(\mathrm{~d}, J=8.5 \mathrm{~Hz}, 2 \mathrm{H}), 7.75(\mathrm{~d}, J=8.9$ $\mathrm{Hz}, 2 \mathrm{H}), 7.40(\mathrm{dd}, J=7.6,1.1 \mathrm{~Hz}, 1 \mathrm{H}), 7.32-7.22(\mathrm{~m}, 2 \mathrm{H}), 7.12(\mathrm{~d}, J=8.9 \mathrm{~Hz}, 2 \mathrm{H}), 6.18(\mathrm{~s}, 1 \mathrm{H})$, 4.39 (brs, $2 \mathrm{H}), 4.16(\mathrm{t}, J=6.2 \mathrm{~Hz}, 2 \mathrm{H}), 3.77-3.66(\mathrm{~m}, 4 \mathrm{H}), 3.44-3.35(\mathrm{~m}, 2 \mathrm{H}), 3.34-3.20(\mathrm{~m}$, $2 \mathrm{H}), 3.17(\mathrm{~s}, 2 \mathrm{H}), 2.84(\mathrm{t}, J=2.6 \mathrm{~Hz}, 1 \mathrm{H}), 2.46(\mathrm{~s}, 3 \mathrm{H}), 2.36(\mathrm{td}, J=7.1,2.6 \mathrm{~Hz}, 2 \mathrm{H}), 2.24(\mathrm{~s}, 3 \mathrm{H})$, $1.93\left(\mathrm{p}, J=6.7 \mathrm{~Hz}, 2 \mathrm{H}\right.$ ); HRMS (ESI) calcd for $\mathrm{C}_{41} \mathrm{H}_{42} \mathrm{ClN}_{8} \mathrm{O}_{4} \mathrm{~S} 777.2739\left[\mathrm{M}+\mathrm{H}^{+}\right]$, found 777.2736 .
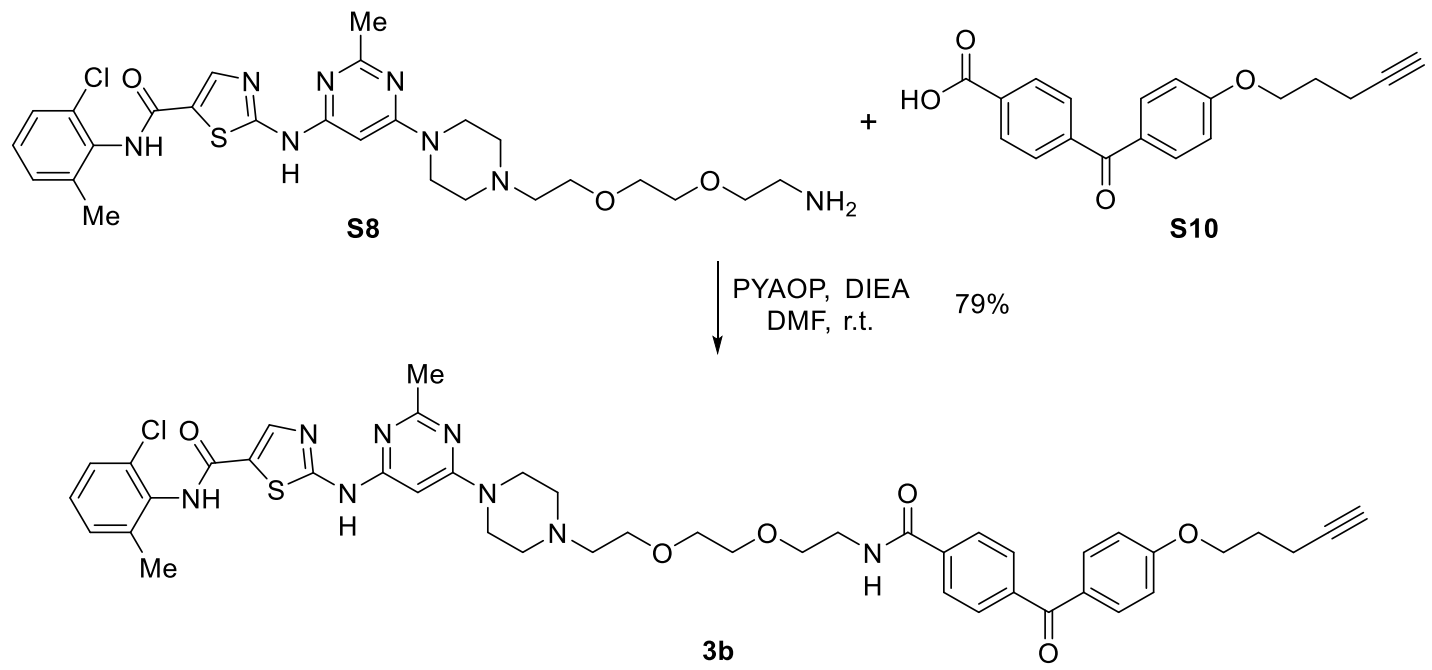

Synthesis of 3b: A solution of dasatinib amine.3TFA salt $\mathbf{S 8}$ (30mg, $0.033 \mathrm{mmol})$, benzoic acid S10 (11.09 mg, $0.036 \mathrm{mmol})$, PyAOP $(18.76 \mathrm{mg}, 0.036 \mathrm{mmol})$ and ethyldiisopropylamine $(0.023$ $\mathrm{mL}, 0.131 \mathrm{mmol})$ were combined in DMF $(3 \mathrm{~mL})$ and stirred for $2 \mathrm{hrs}$ at r.t. The crude reaction 
mix was diluted with $90 \% \mathrm{DMSO} /$ water to $4 \mathrm{~mL}$ and purified on preparative HPLC. The eluents were A: $0.1 \%$ TFA-water; B: acetonitrile. $0-5 \mathrm{~min}$ isocratic; $1 \% / \mathrm{min}$ acetonitrile gradient after that point. The appropriate fractions were collected and lyophilized to dryness to give the titled compound (28.4 mg, 79\% yield): ${ }^{1} \mathrm{H}$ NMR (500 MHz, DMSO- $\left.d_{6}\right) \delta 11.65$ (brs, $\left.1 \mathrm{H}\right), 10.06$ (brs, $1 \mathrm{H}), 9.92(\mathrm{~s}, 1 \mathrm{H}), 8.74(\mathrm{t}, J=5.5 \mathrm{~Hz}, 1 \mathrm{H}), 8.24(\mathrm{~s}, 1 \mathrm{H}), 8.00(\mathrm{~d}, J=8.3 \mathrm{~Hz}, 2 \mathrm{H}), 7.75(\mathrm{~d}, J=8.3$ $\mathrm{Hz}, 2 \mathrm{H}), 7.72(\mathrm{~d}, J=8.8 \mathrm{~Hz}, 2 \mathrm{H}), 7.40(\mathrm{~d}, J=6.7 \mathrm{~Hz}, 1 \mathrm{H}), 7.31-7.19(\mathrm{~m}, 2 \mathrm{H}), 7.08(\mathrm{~d}, J=8.8$ $\mathrm{Hz}, 2 \mathrm{H}), 6.16(\mathrm{~s}, 1 \mathrm{H}), 4.33$ (brs, $2 \mathrm{H}), 4.13(\mathrm{t}, J=6.2 \mathrm{~Hz}, 2 \mathrm{H}), 3.83-3.74(\mathrm{~m}, 2 \mathrm{H}), 3.66-3.53(\mathrm{~m}$, $8 \mathrm{H}), 3.52-3.43(\mathrm{~m}, 2 \mathrm{H}), 3.34(\mathrm{~s}, 2 \mathrm{H}), 3.26(\mathrm{brs}, 2 \mathrm{H}), 3.17(\mathrm{~s}, 2 \mathrm{H}), 3.10(\mathrm{~s}, 2 \mathrm{H}), 2.82(\mathrm{t}, J=2.6$ $\mathrm{Hz}, 1 \mathrm{H}), 2.43(\mathrm{~s}, 3 \mathrm{H}), 2.34(\mathrm{td}, J=7.0,2.6 \mathrm{~Hz}, 2 \mathrm{H}), 2.24(\mathrm{~s}, 3 \mathrm{H}), 1.92(\mathrm{p}, J=6.6 \mathrm{~Hz}, 2 \mathrm{H})$; HRMS (ESI) calcd for $\mathrm{C}_{45} \mathrm{H}_{49} \mathrm{C}_{1} \mathrm{~N}_{8} \mathrm{O}_{6} \mathrm{~S} 865.3263\left[\mathrm{M}+\mathrm{H}^{+}\right]$, found 865.3278.
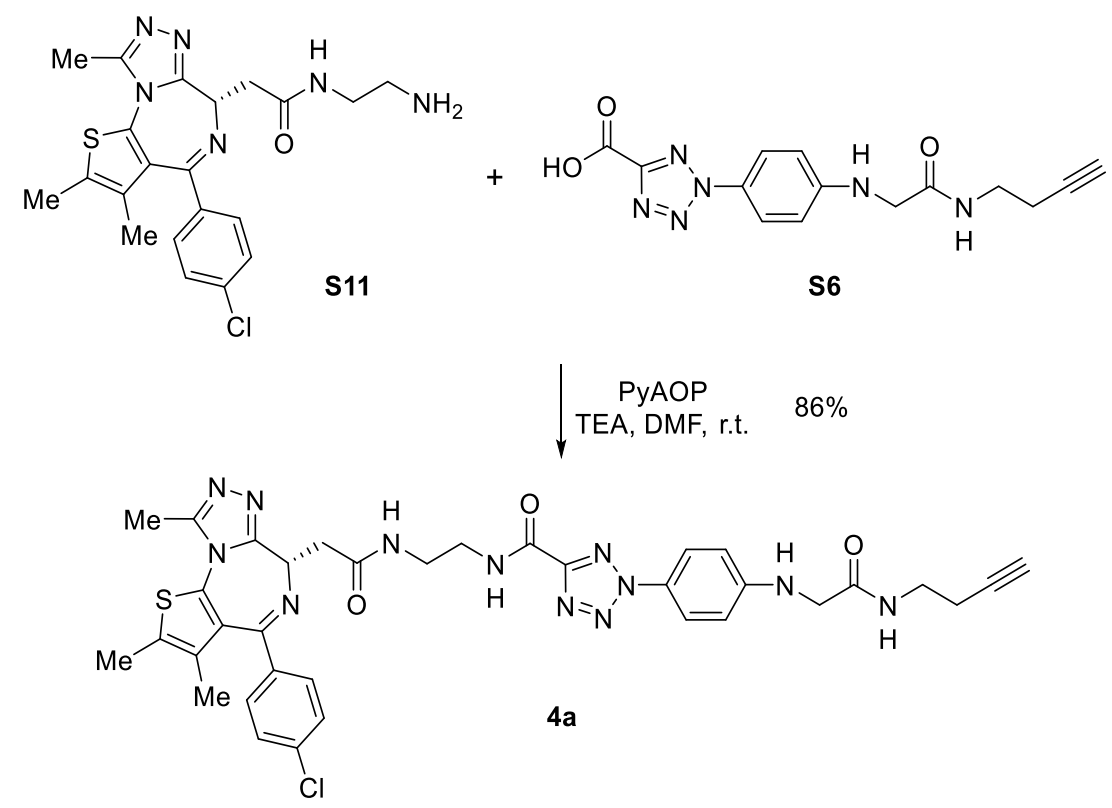

Synthesis of 4a: A solution of (+)-JQ-1 amine.TFA salt S11 (10.0 mg, $0.018 \mathrm{mmol})$, tetrazole carboxylic acid S6 (6.2 mg, $0.020 \mathrm{mmol})$, PyAOP (11.2 mg, $0.022 \mathrm{mmol})$, and triethylamine (6.3 $\mu \mathrm{L}, 0.045 \mathrm{mmol}$ ) in $150 \mu \mathrm{L} \mathrm{DMF}$ was stirred at r.t. for $2 \mathrm{~h}$. The reaction mixture was applied to a medium-pressure silica gel flash chromatography system equipped with an automatic fraction collector running the $\mathrm{MeOH} / \mathrm{CH}_{2} \mathrm{Cl}_{2}(1: 99 \rightarrow 10: 90)$ eluent gradient. The suitable fractions were pooled and evaporated under reduced pressure. The residue was re-dissolved in $3 \mathrm{~mL} \mathrm{MeCN}$ and $3 \mathrm{~mL} \mathrm{H}_{2} \mathrm{O}$ containing $0.5 \%$ TFA, and the solution was lyophilized to dryness to give the titled compound as a white powder $(11.4 \mathrm{mg}, 86 \%$ yield $): \mathrm{R}_{f}=0.40\left(\mathrm{MeOH} / \mathrm{CH}_{2} \mathrm{Cl}_{2}=1: 10\right):{ }^{1} \mathrm{H} \mathrm{NMR}$ $\left(500 \mathrm{MHz}, \mathrm{CD}_{3} \mathrm{OD}\right) \delta 7.89(\mathrm{~d}, J=8.9 \mathrm{~Hz}, 2 \mathrm{H}), 7.39(\mathrm{~d}, J=8.4 \mathrm{~Hz}, 2 \mathrm{H}), 7.35(\mathrm{~d}, J=8.5 \mathrm{~Hz}, 2 \mathrm{H})$, $6.76(\mathrm{~d}, J=8.9 \mathrm{~Hz}, 2 \mathrm{H}), 4.65(\mathrm{dd}, J=8.0,6.2 \mathrm{~Hz}, 1 \mathrm{H}), 3.85(\mathrm{~s}, 2 \mathrm{H}), 3.63(\mathrm{t}, J=5.4 \mathrm{~Hz}, 2 \mathrm{H}), 3.56$ $(\mathrm{t}, J=5.4 \mathrm{~Hz}, 2 \mathrm{H}), 3.46-3.33(\mathrm{~m}, 4 \mathrm{H}), 3.21(\mathrm{q}, J=7.3 \mathrm{~Hz}, 1 \mathrm{H}), 2.66(\mathrm{~s}, 3 \mathrm{H}), 2.40(\mathrm{~s} 3 \mathrm{H}), 2.37$ $(\mathrm{td}, J=6.8,2.3 \mathrm{~Hz}, 2 \mathrm{H}), 2.25(\mathrm{~s}, 1 \mathrm{H}), 1.62(\mathrm{~s}, 3 \mathrm{H})$; HRMS (ESI) calcd for $\mathrm{C}_{35} \mathrm{H}_{36} \mathrm{ClN}_{12} \mathrm{O}_{3} \mathrm{~S}$ $739.2437\left[\mathrm{M}+\mathrm{H}^{+}\right]$, found 739.2419 . The product purity was verified by analytical HPLC. 

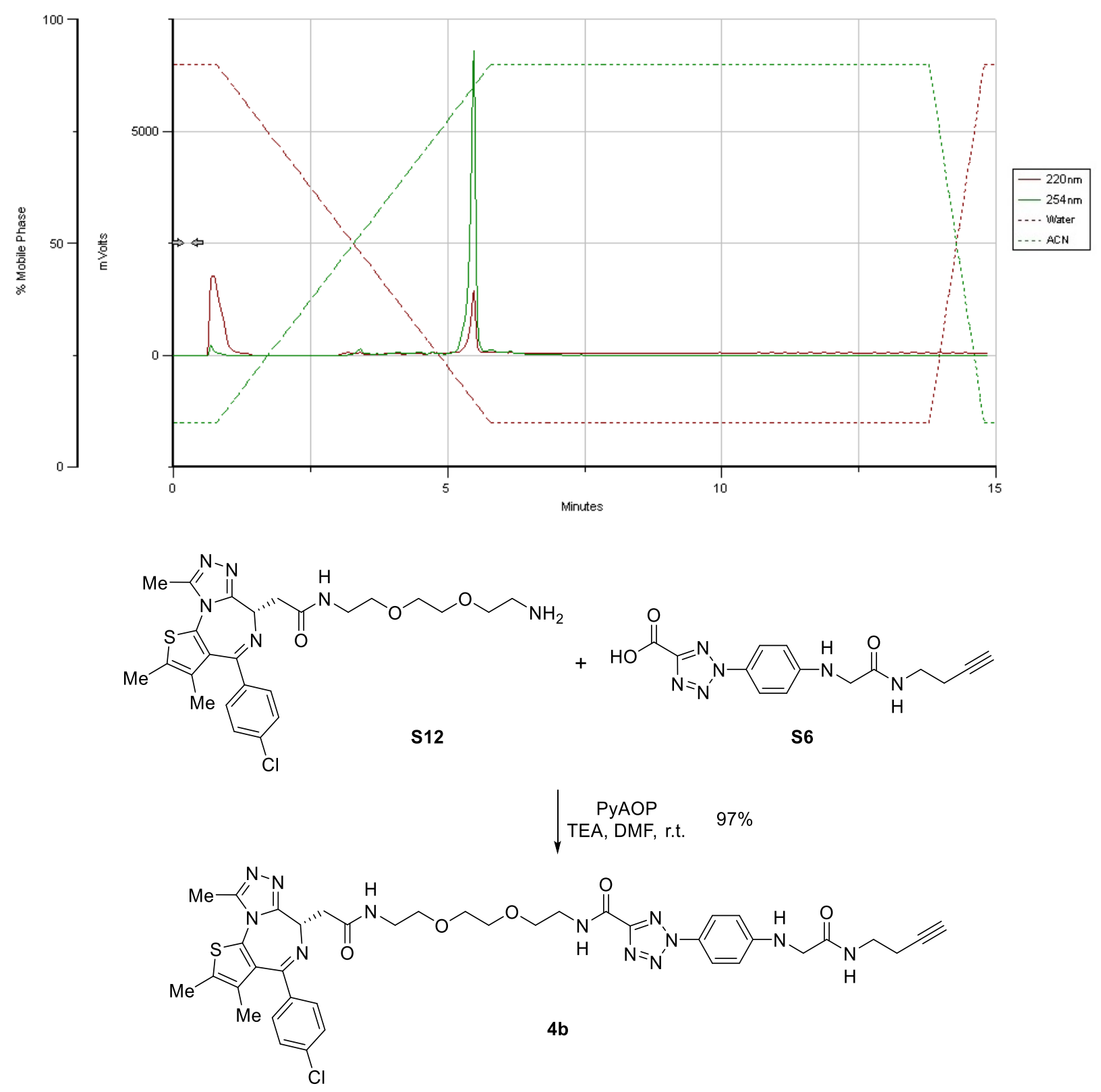

Synthesis of 4b: A solution of (+)-JQ-1 amine.TFA salt $\mathbf{S 1 2}(10.0 \mathrm{mg}, 0.016 \mathrm{mmol})$, tetrazole carboxylic acid S6 (5.4 mg, $0.017 \mathrm{mmol})$, PyAOP $(9.7 \mathrm{mg}, 0.019 \mathrm{mmol})$, and triethylamine (5.4 $\mu \mathrm{L}, 0.039 \mathrm{mmol}$ ) in $150 \mu \mathrm{L}$ DMF was stirred at r.t. for $4 \mathrm{~h}$. The reaction mixture was applied to a medium-pressure silica gel flash chromatography system equipped with an automatic fraction collector running the $\mathrm{MeOH} / \mathrm{CH}_{2} \mathrm{Cl}_{2}(1: 99 \rightarrow 10: 90)$ eluent gradient. The suitable fractions were pooled and evaporated under reduced pressure. The residue was re-dissolved in $3 \mathrm{~mL} \mathrm{MeCN}$ and $3 \mathrm{~mL} \mathrm{H}_{2} \mathrm{O}$ containing $0.5 \%$ TFA, and the solution was lyophilized to dryness to give the titled compound as a white powder (12.8 mg, 97\% yield): $\mathrm{R}_{f}=0.36\left(\mathrm{MeOH} / \mathrm{CH}_{2} \mathrm{Cl}_{2}=1: 10\right) ;{ }^{1} \mathrm{H} \mathrm{NMR}$ $\left(500 \mathrm{MHz}, \mathrm{CD}_{3} \mathrm{OD}\right) \delta 7.86(\mathrm{~d}, J=8.9 \mathrm{~Hz}, 2 \mathrm{H}), 7.43(\mathrm{~d}, J=8.4 \mathrm{~Hz}, 2 \mathrm{H}), 7.38(\mathrm{~d}, J=8.5 \mathrm{~Hz}, 2 \mathrm{H})$, $6.73(\mathrm{~d}, J=8.9 \mathrm{~Hz}, 2 \mathrm{H}), 4.64(\mathrm{dd}, J=8.7,5.4 \mathrm{~Hz}, 1 \mathrm{H}), 4.58(\mathrm{~s}, 0.6 \mathrm{H}), 3.83(\mathrm{~s}, 2 \mathrm{H}), 3.75-3.59$ $(\mathrm{m}, 11 \mathrm{H}), 3.50-3.40(\mathrm{~m}, 3 \mathrm{H}), 3.39-3.32(\mathrm{~m}$, under the solvent signal), $2.67(\mathrm{~s}, 3 \mathrm{H}), 2.42(\mathrm{~s} 3 \mathrm{H})$, $2.37(\mathrm{td}, J=6.8,2.5 \mathrm{~Hz}, 2 \mathrm{H}), 2.25(\mathrm{t}, J=2.4 \mathrm{~Hz}, 1 \mathrm{H}), 1.66(\mathrm{~s}, 3 \mathrm{H})$; HRMS (ESI) calcd for 
$\mathrm{C}_{39} \mathrm{H}_{44} \mathrm{ClN}_{12} \mathrm{O}_{5} \mathrm{~S} 827.2961\left[\mathrm{M}+\mathrm{H}^{+}\right]$, found 827.2946 . The product purity was also verified by analytical HPLC.
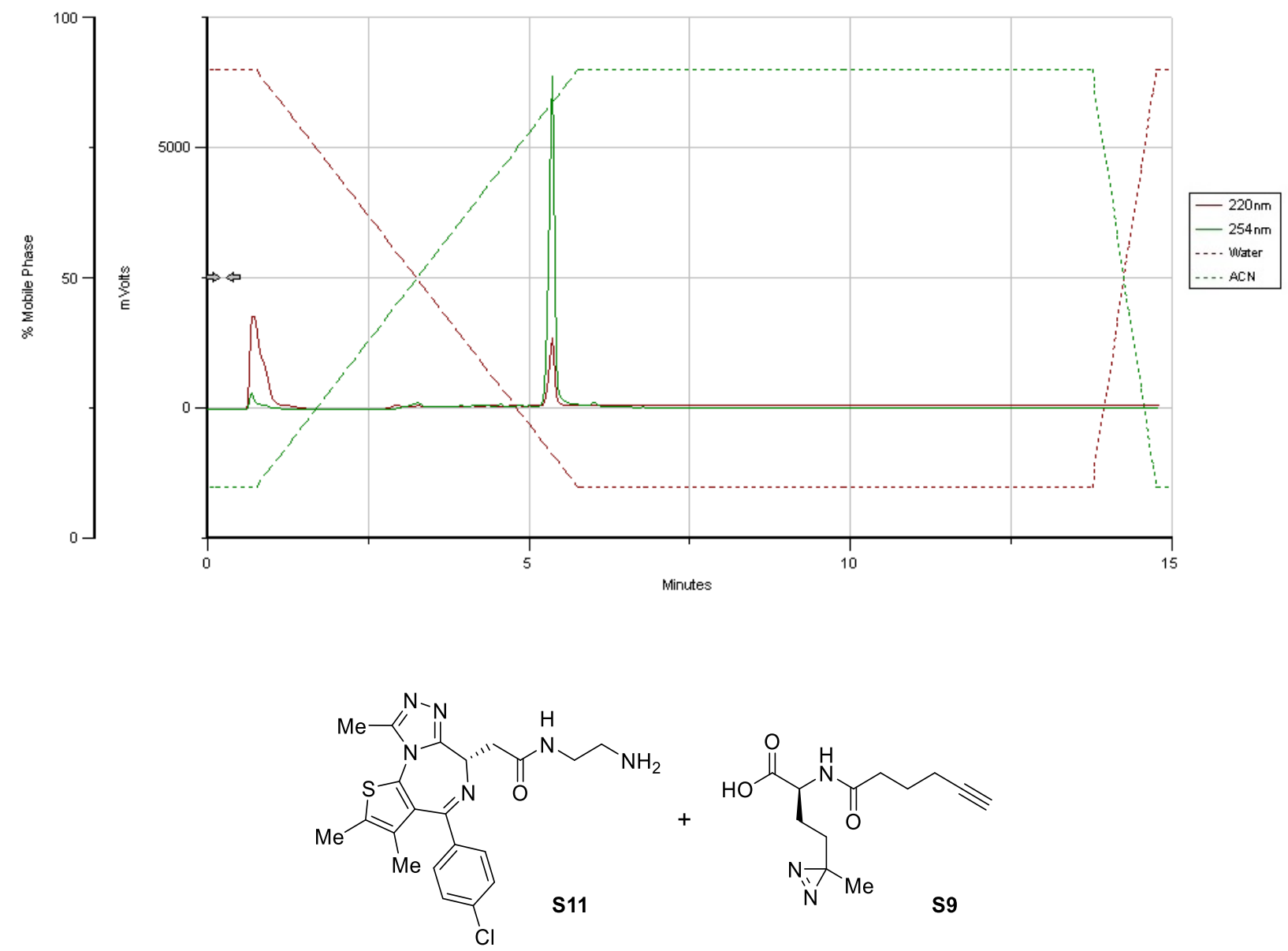

$\downarrow \begin{gathered}\text { PyAOP } \\ \text { DIEA, DMF, r.t. }\end{gathered}$

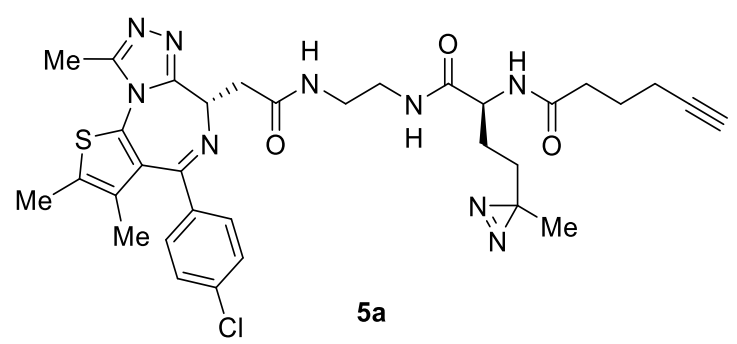

Synthesis of 5a: A solution of (+)-JQ-1 amine.TFA salt S11 (20 mg, $0.036 \mathrm{mmol})$, diazirine acid S9 $(12.21 \mathrm{mg}, 0.049 \mathrm{mmol})$, PyAOP $(28.1 \mathrm{mg}, 0.054 \mathrm{mmol})$ and ethyldiisopropylamine $(0.025$ $\mathrm{mL}, 0.144 \mathrm{mmol})$ were combined in DMF $(2 \mathrm{~mL})$ and stirred for $2 \mathrm{~h}$ at r.t. The crude reaction mix was diluted with $90 \% \mathrm{DMSO} /$ water to $4 \mathrm{~mL}$ and purified on preparative HPLC. The eluents were A: $0.1 \%$ TFA-water; B: acetonitrile. $0-5 \mathrm{~min}$ isocratic; $1 \% / \mathrm{min}$ acetonitrile gradient after that point. The appropriate fractions were collected and lyophilized to dryness to give the titled compound (18 mg, 74\% yield): ${ }^{1} \mathrm{H}$ NMR $\left(500 \mathrm{MHz}, \mathrm{DMSO}-d_{6}\right) \delta 8.20(\mathrm{~s}, 1 \mathrm{H}), 7.95$ (d, $J=7.8$ $\mathrm{Hz}, 1 \mathrm{H}), 7.90(\mathrm{t}, J=5.0 \mathrm{~Hz}, 1 \mathrm{H}), 7.48(\mathrm{~d}, J=8.7 \mathrm{~Hz}, 2 \mathrm{H}), 7.42(\mathrm{~d}, J=8.5 \mathrm{~Hz}, 2 \mathrm{H}), 4.52(\mathrm{t}, J=$ $7.1 \mathrm{~Hz}, 1 \mathrm{H}), 4.10(\mathrm{td}, J=8.0,5.2 \mathrm{~Hz}, 1 \mathrm{H}), 3.24(\mathrm{~d}, J=7.1 \mathrm{~Hz}, 2 \mathrm{H}), 3.20-3.08(\mathrm{~m}, 4 \mathrm{H}), 2.73(\mathrm{t}$, 
$J=2.6 \mathrm{~Hz}, 1 \mathrm{H}), 2.60(\mathrm{~s}, 3 \mathrm{H}), 2.40(\mathrm{~s}, 3 \mathrm{H}), 2.20(\mathrm{t}, J=7.5 \mathrm{~Hz}, 2 \mathrm{H}), 2.11(\mathrm{td}, J=7.1,2.6 \mathrm{~Hz}, 2 \mathrm{H})$, $1.67-1.58(\mathrm{~m}, 5 \mathrm{H}), 1.54-1.45(\mathrm{~m}, 1 \mathrm{H}), 1.38-1.21(\mathrm{~m}, 3 \mathrm{H}), 0.94(\mathrm{~s}, 3 \mathrm{H})$; HRMS (ESI) calcd for $\mathrm{C}_{33} \mathrm{H}_{39} \mathrm{ClN}_{9} \mathrm{O}_{3} \mathrm{SNa} 698.2405\left[\mathrm{M}+\mathrm{Na}^{+}\right]$, found 698.2422.
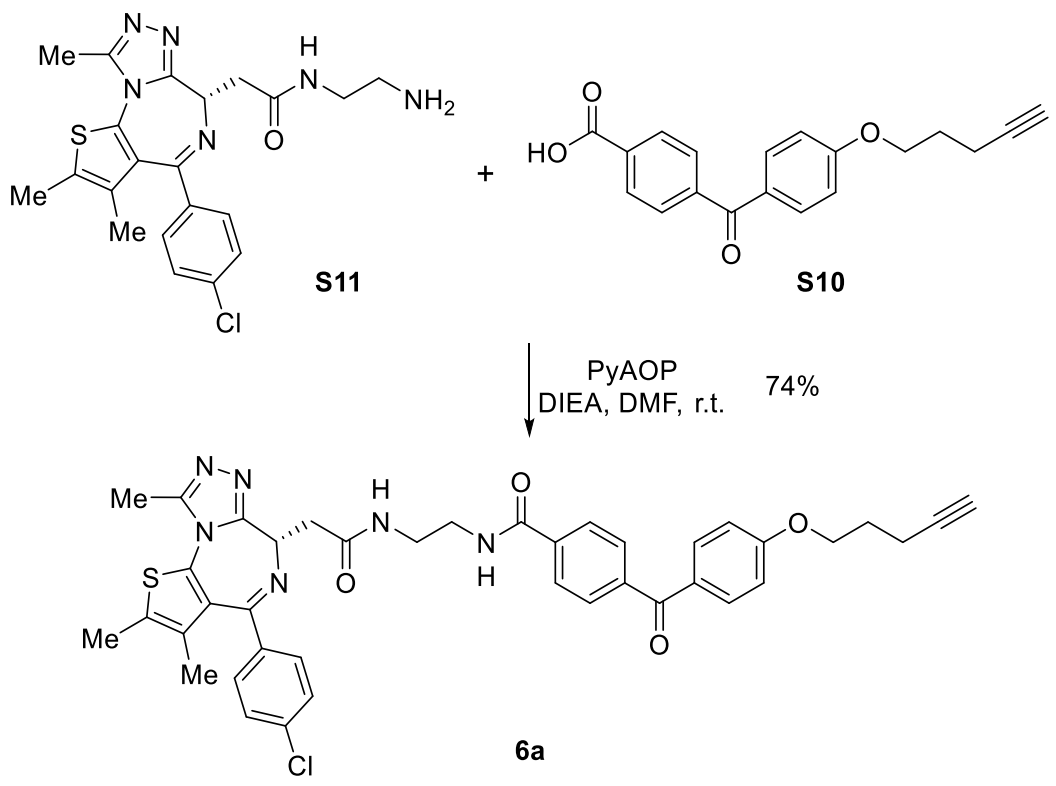

Synthesis of 6a: A solution of (+)-JQ-1 amine.TFA salt S11 (25 mg, $0.045 \mathrm{mmol})$, benzoic acid S10 (15.22 mg, $0.049 \mathrm{mmol})$, PyAOP (25.7 $\mathrm{mg}, 0.049 \mathrm{mmol})$ and ethyldiisopropylamine (0.031 $\mathrm{mL}, 0.180 \mathrm{mmol})$ were combined in DMF $(3 \mathrm{~mL})$ and stirred for $2 \mathrm{~h}$ at r.t. The crude reaction mix was diluted with $90 \% \mathrm{DMSO} /$ water to $4 \mathrm{~mL}$ and purified on preparative HPLC. The eluents were A: $0.1 \%$ TFA-water; B: acetonitrile. $0-5 \mathrm{~min}$ isocratic; $1 \% / \mathrm{min}$ acetonitrile gradient after that point. The appropriate fractions were collected and lyophilized to dryness to give the titled compound (24 mg, 74\% yield): ${ }^{1} \mathrm{H}$ NMR $\left(500 \mathrm{MHz}, \mathrm{DMSO}-d_{6}\right) \delta 8.66(\mathrm{t}, J=5.2 \mathrm{~Hz}, 1 \mathrm{H}), 8.41(\mathrm{t}$, $J=5.6 \mathrm{~Hz}, 1 \mathrm{H}), 7.98(\mathrm{~d}, J=8.3 \mathrm{~Hz}, 2 \mathrm{H}), 7.77-7.73(\mathrm{~m}, 4 \mathrm{H}), 7.46(\mathrm{~d}, J=8.7 \mathrm{~Hz}, 2 \mathrm{H}), 7.42(\mathrm{~d}$, $J=8.6 \mathrm{~Hz}, 2 \mathrm{H}), 7.12(\mathrm{~d}, J=8.8 \mathrm{~Hz}, 2 \mathrm{H}), 4.55(\mathrm{t}, J=7.1 \mathrm{~Hz}, 1 \mathrm{H}), 4.17(\mathrm{t}, J=6.2 \mathrm{~Hz}, 2 \mathrm{H}), 3.42-$ $3.22(\mathrm{~m}$, under the water signal), $2.84(\mathrm{t}, J=2.6 \mathrm{~Hz}, 1 \mathrm{H}), 2.59(\mathrm{~s}, 3 \mathrm{H}), 2.41(\mathrm{~s}, 3 \mathrm{H}), 2.37(\mathrm{td}, J=$ 7.1, $2.6 \mathrm{~Hz}, 2 \mathrm{H}), 1.95$ (p, $J=6.5 \mathrm{~Hz}, 2 \mathrm{H}), 1.60$ (s, 3H); HRMS (ESI) calcd for $\mathrm{C}_{40} \mathrm{H}_{37} \mathrm{ClN}_{6} \mathrm{O}_{4} \mathrm{~S}$ $733.2365\left[\mathrm{M}+\mathrm{H}^{+}\right]$, found 733.2354 . 


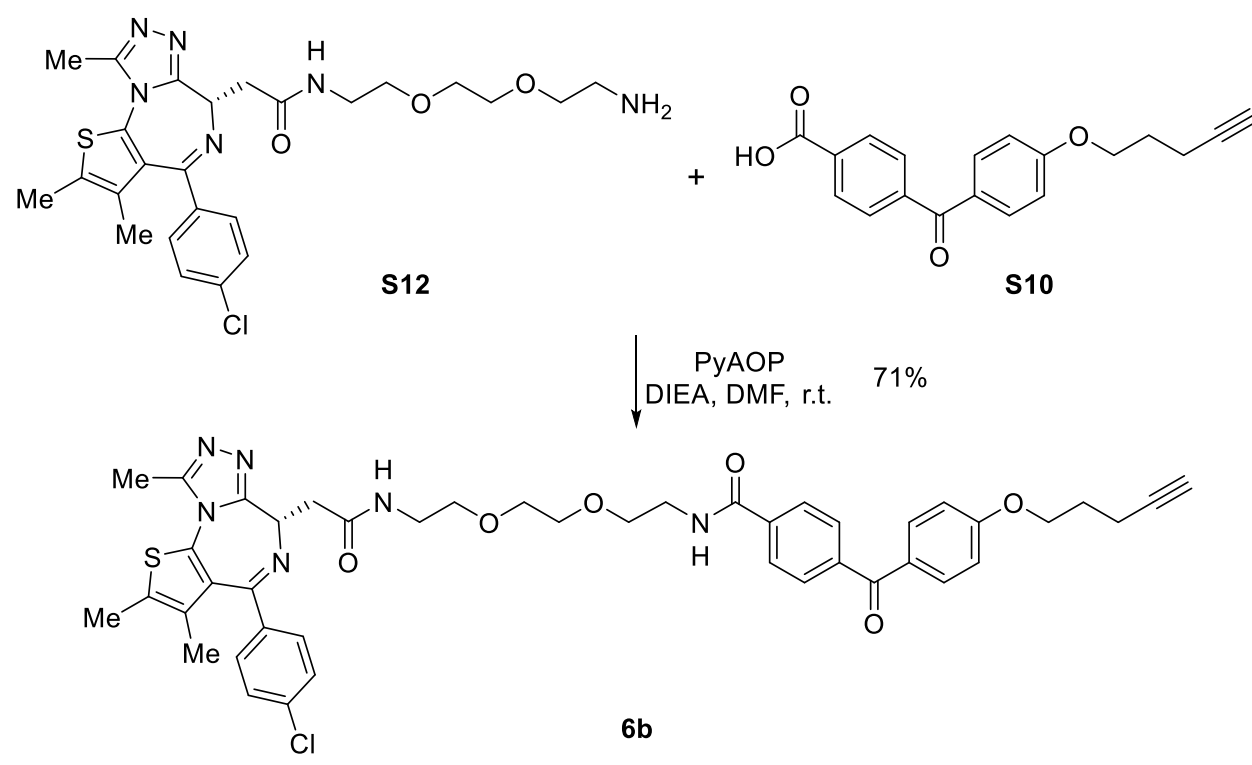

Synthesis of 6b: A solution of (+)-JQ-1 amine.TFA salt S12 (25 mg, $0.033 \mathrm{mmol})$, benzoic acid S10 (11.17 mg, $0.036 \mathrm{mmol})$, PyAOP (18.89 mg, $0.036 \mathrm{mmol}$ ) and ethyldiisopropylamine (0.023 $\mathrm{mL}, 0.132 \mathrm{mmol})$ were combined in DMF $(3 \mathrm{~mL})$ and stirred for $2 \mathrm{~h}$ at r.t. The crude reaction mix was diluted with $90 \% \mathrm{DMSO} /$ water to $4 \mathrm{~mL}$ and purified on preparative HPLC. The eluents were A: $0.1 \%$ TFA-water; B: acetonitrile. $0-5 \mathrm{~min}$ isocratic; $1 \% / \mathrm{min}$ acetonitrile gradient after that point. The appropriate fractions were collected and lyophilized to dryness to give the titled compound (19.1 mg, 71\% yield): ${ }^{1} \mathrm{H}$ NMR (500 MHz, DMSO- $\left.d_{6}\right) \delta 8.64(\mathrm{t}, J=5.2 \mathrm{~Hz}, 1 \mathrm{H}), 8.40$ $(\mathrm{t}, J=5.6 \mathrm{~Hz}, 1 \mathrm{H}), 7.96(\mathrm{~d}, J=8.3 \mathrm{~Hz}, 2 \mathrm{H}), 7.77-7.70(\mathrm{~m}, 4 \mathrm{H}), 7.45(\mathrm{~d}, J=8.7 \mathrm{~Hz}, 2 \mathrm{H}), 7.40$ $(\mathrm{d}, J=8.6 \mathrm{~Hz}, 2 \mathrm{H}), 7.10(\mathrm{~d}, J=8.8 \mathrm{~Hz}, 2 \mathrm{H}), 4.53(\mathrm{t}, J=7.1 \mathrm{~Hz}, 1 \mathrm{H}), 4.16(\mathrm{t}, J=6.2 \mathrm{~Hz}, 2 \mathrm{H}), 3.40$ -3.22 (m, under the water signal), 2.82. (t, $J=2.6 \mathrm{~Hz}, 1 \mathrm{H}), 2.58(\mathrm{~s}, 3 \mathrm{H}), 2.39$ (s, 3H), $2.35(\mathrm{td}, J$ $=7.1,2.6 \mathrm{~Hz}, 2 \mathrm{H}), 1.93(\mathrm{p}, J=6.5 \mathrm{~Hz}, 2 \mathrm{H}), 1.58(\mathrm{~s}, 3 \mathrm{H})$; HRMS (ESI) calcd for $\mathrm{C}_{44} \mathrm{H}_{45} \mathrm{ClN}_{6} \mathrm{O}_{6} \mathrm{SNa}$ 843.2708 [M+Na ${ }^{+}$, found 843.2701. 
${ }^{1} \mathrm{H}$ and ${ }^{13} \mathrm{C}$ NMR spectra

$\stackrel{\infty}{i}$

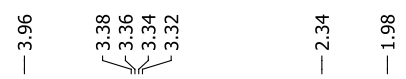
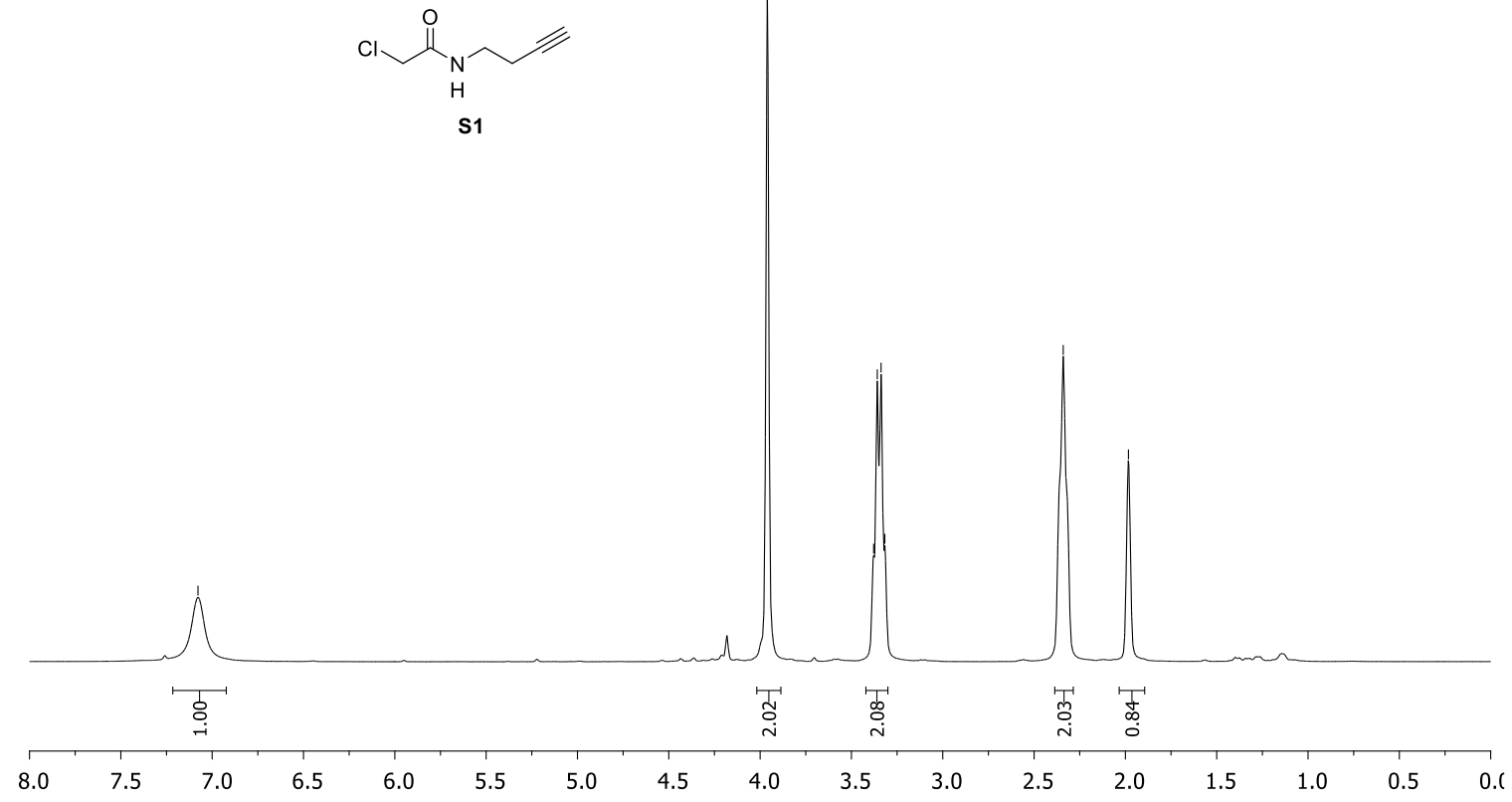

$\overrightarrow{0}$

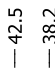

$\stackrel{\circ}{\overrightarrow{1}}$
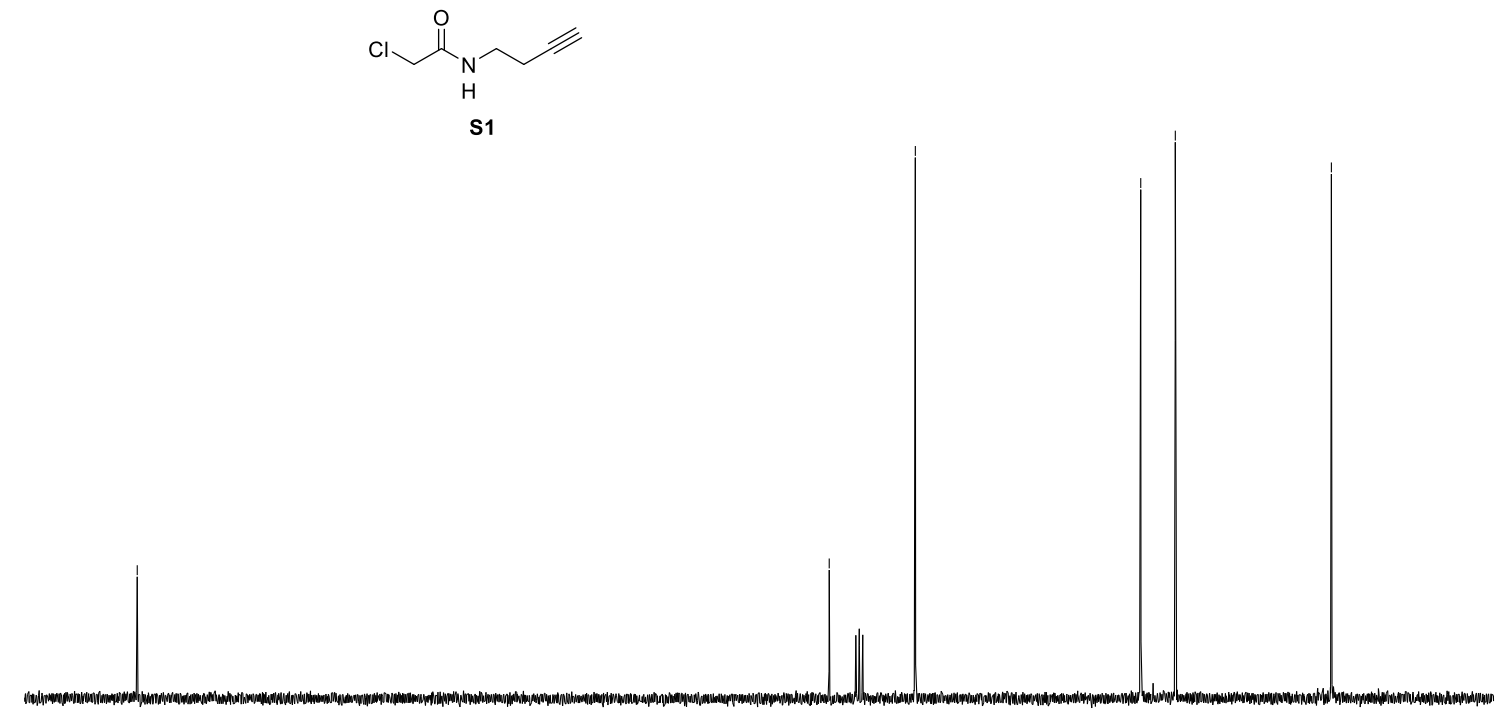

180

170

160

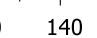

130

$120 \quad 110 \quad 100$

90

$80 \quad 70$

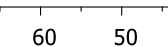

40

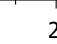

$10 \quad 0$ 


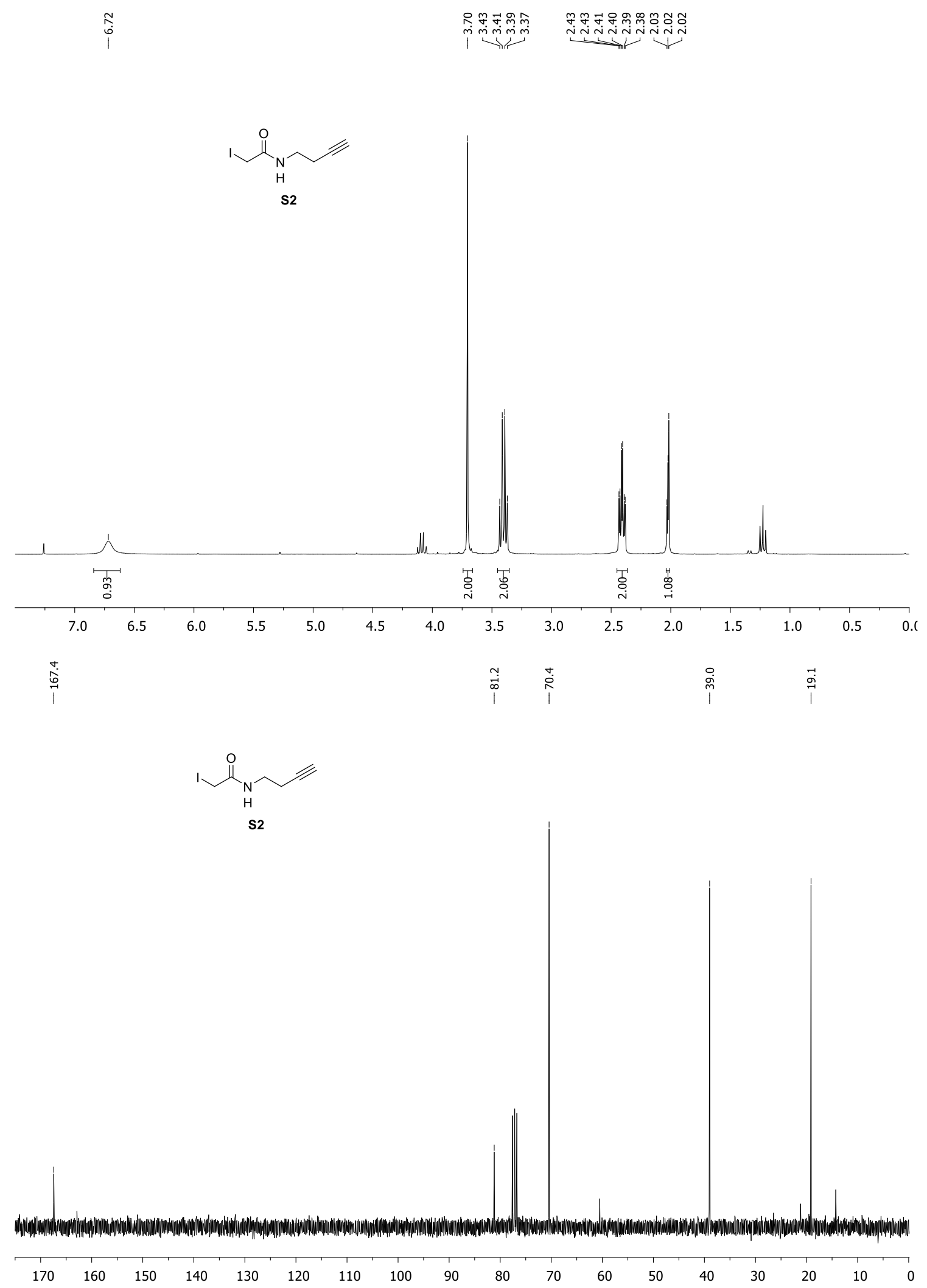




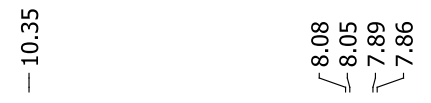

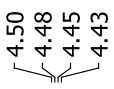
울

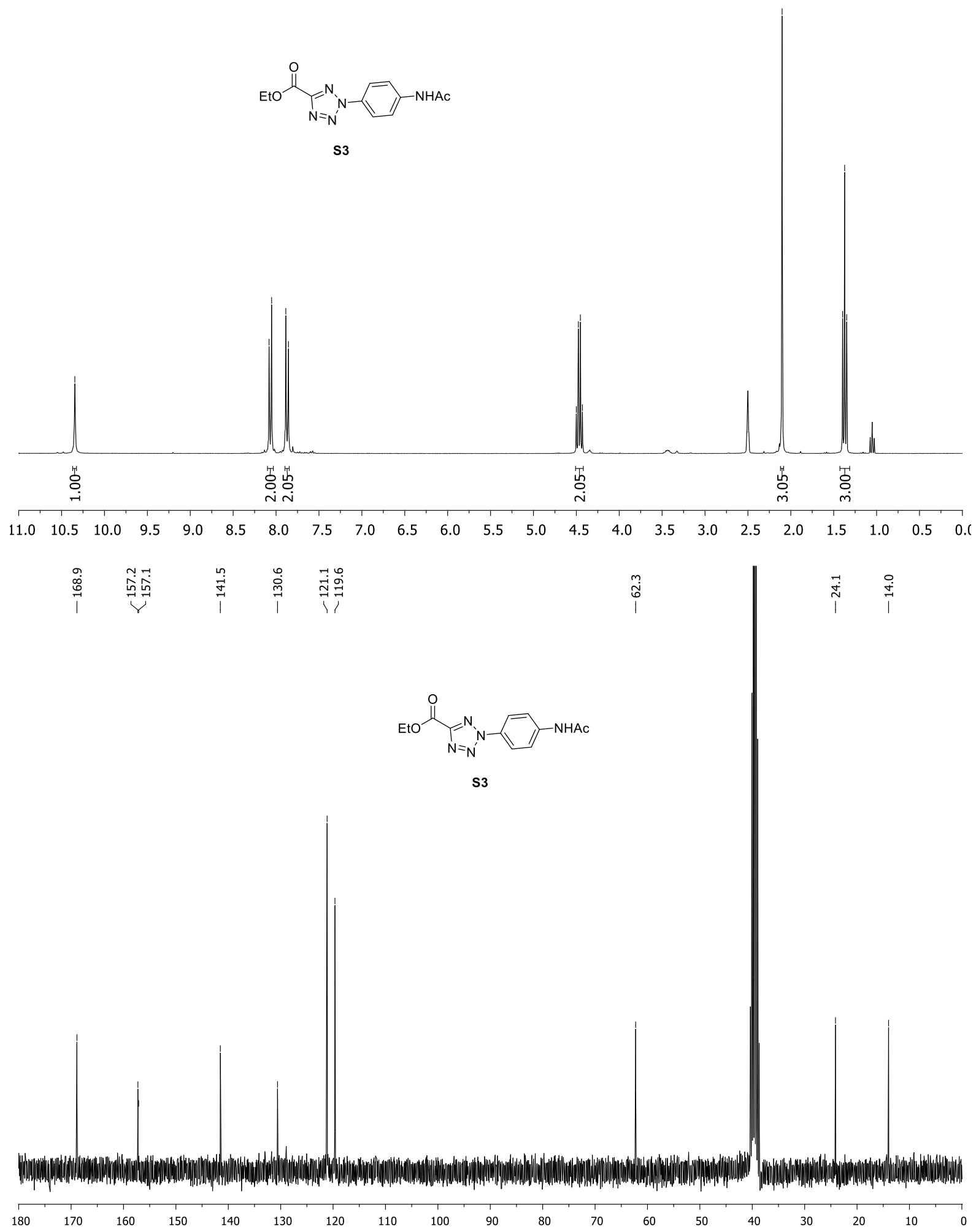



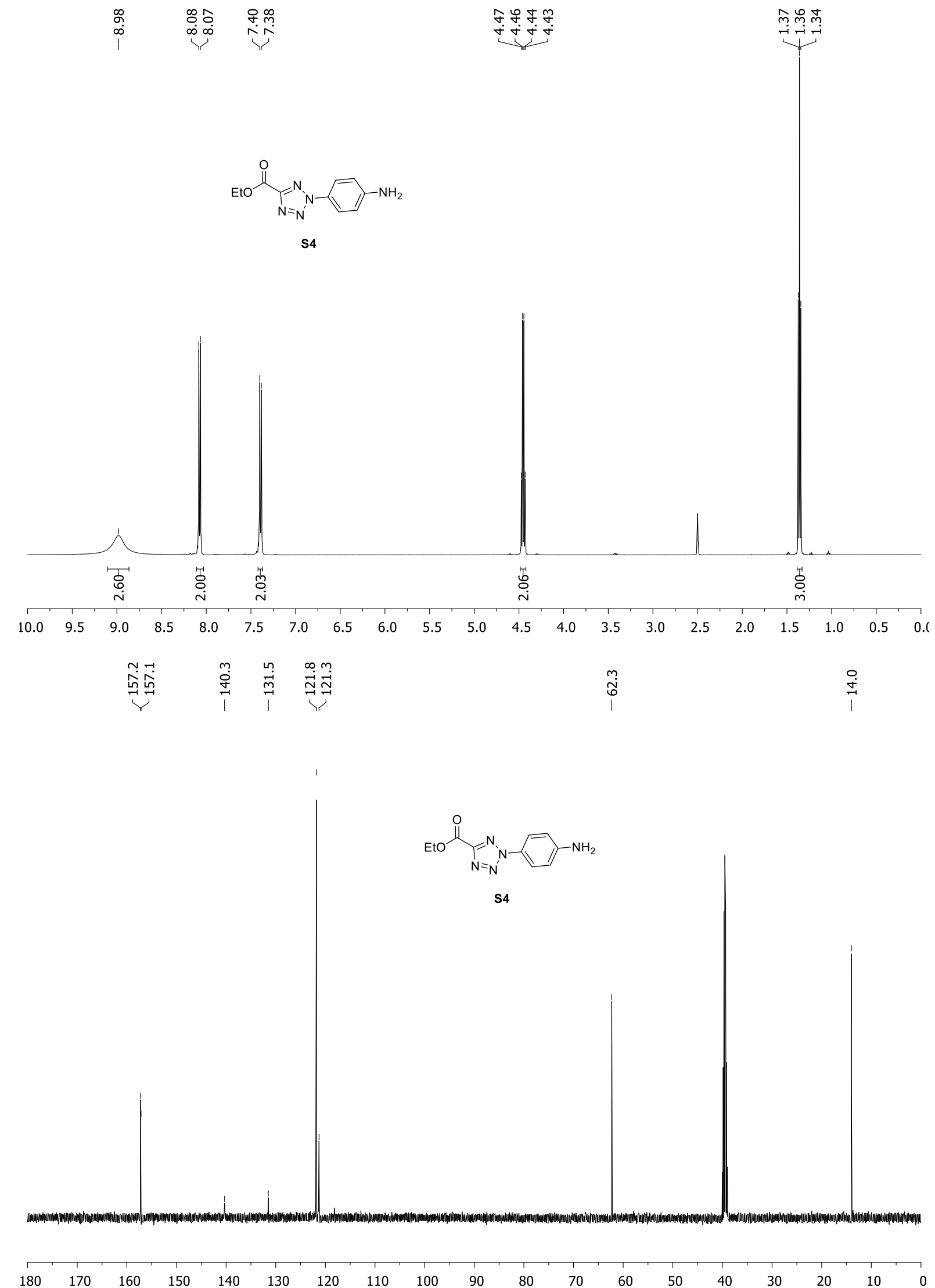

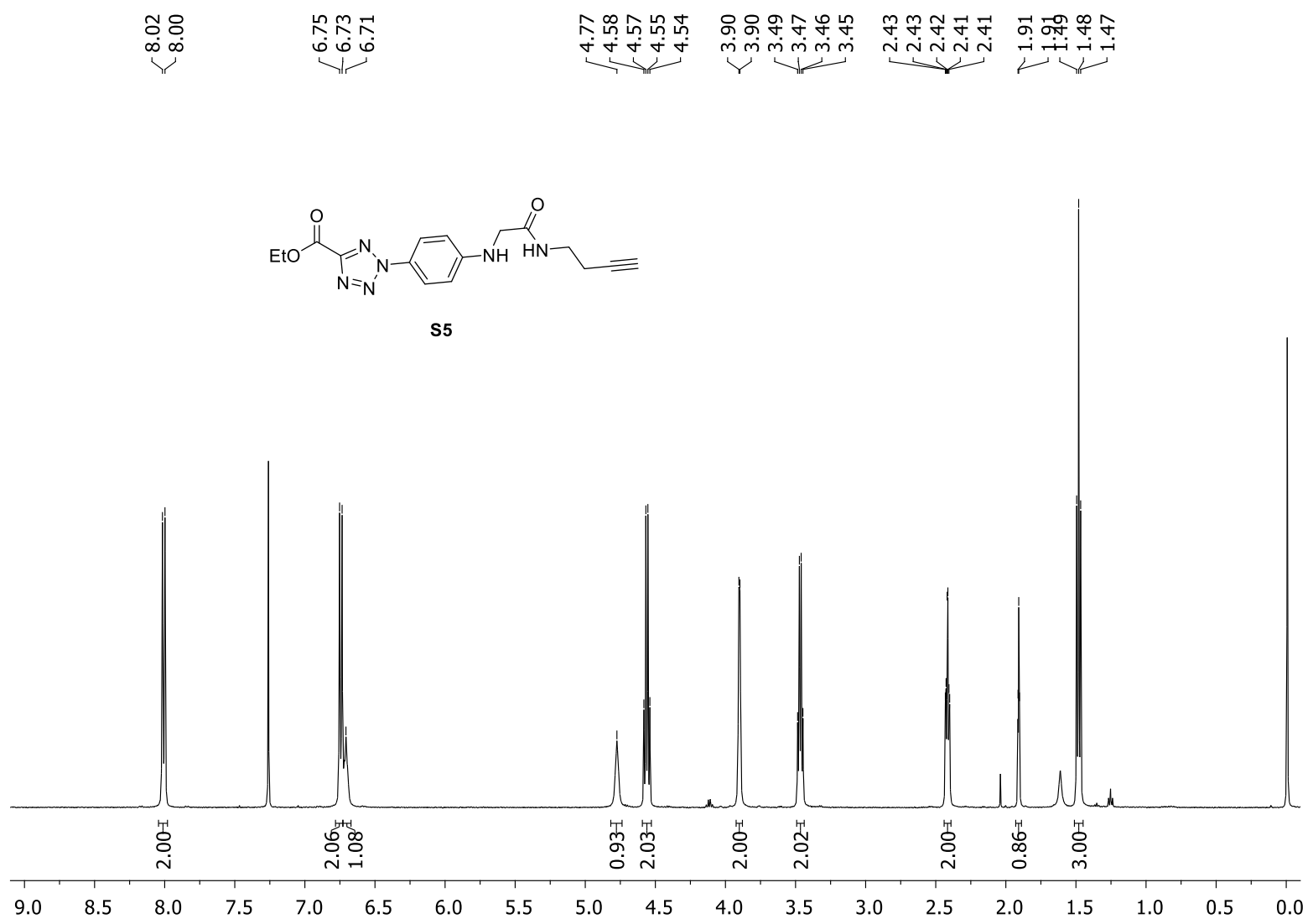

$$
\text { (1) }
$$

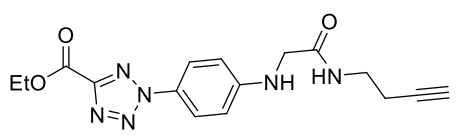

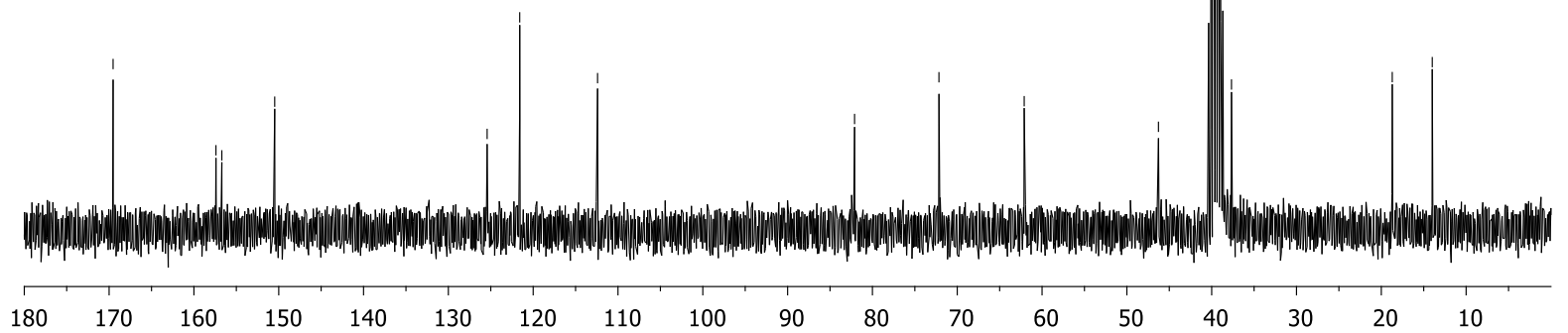




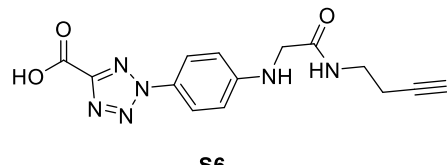

S6

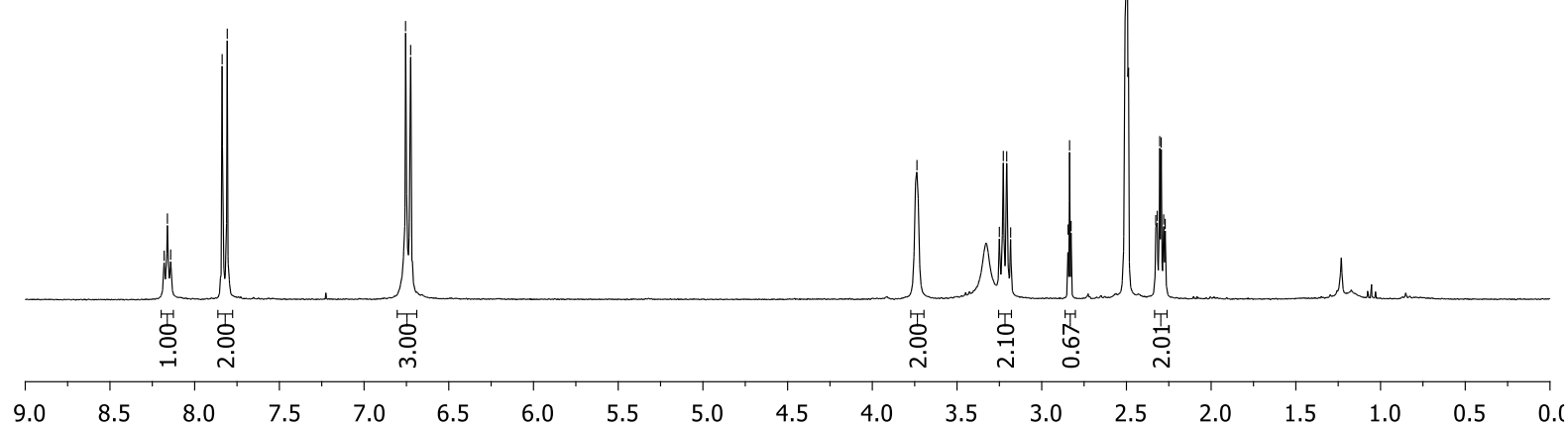

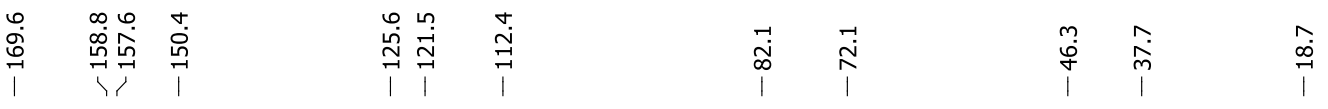

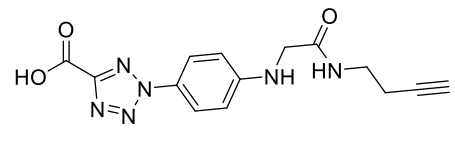

S6
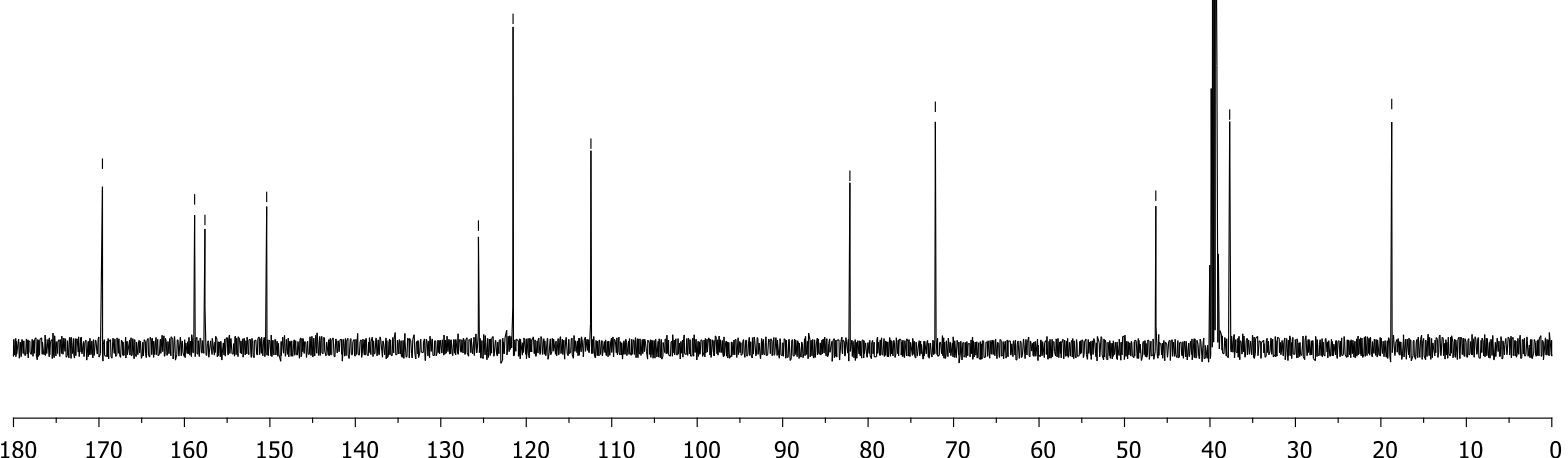


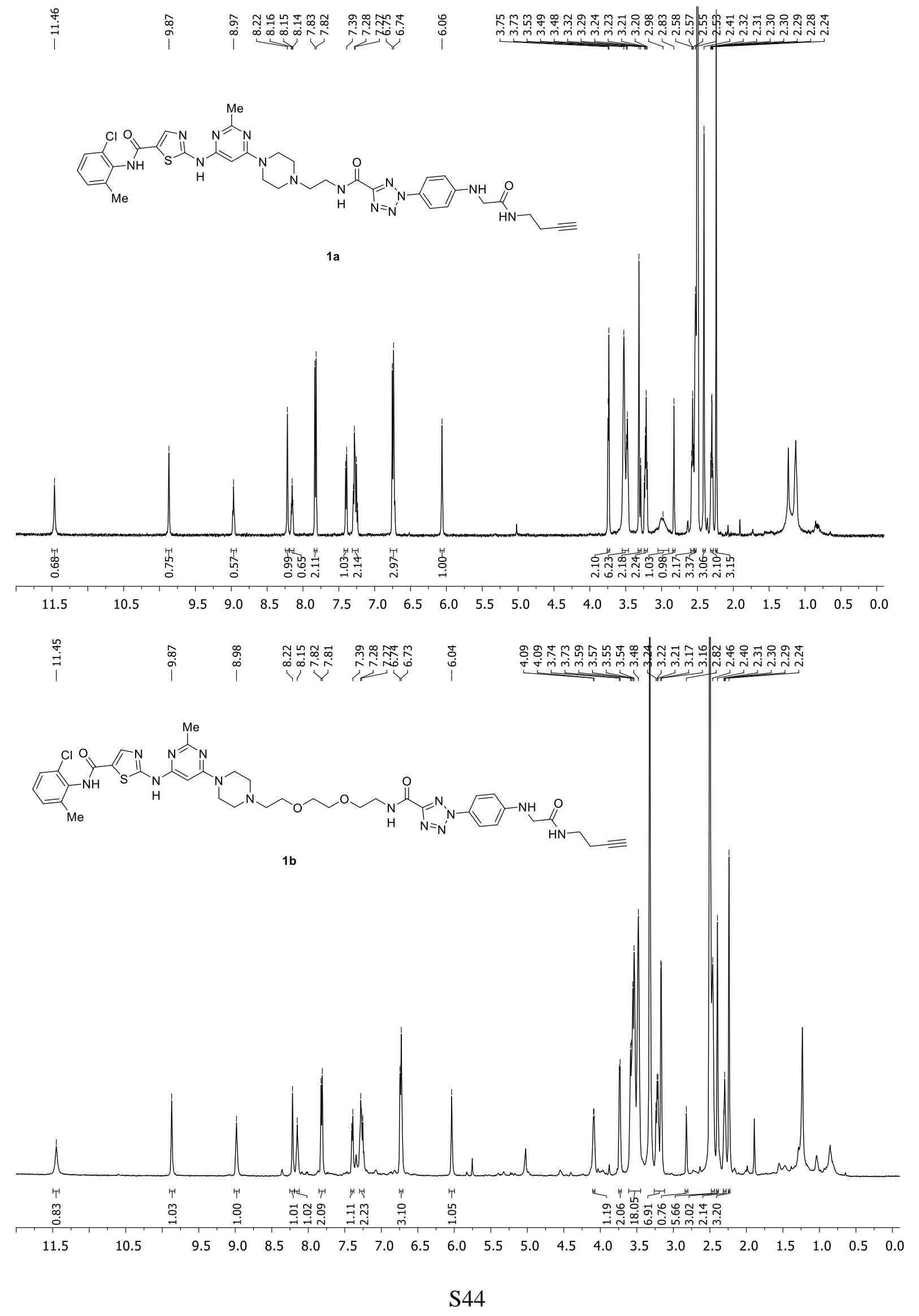




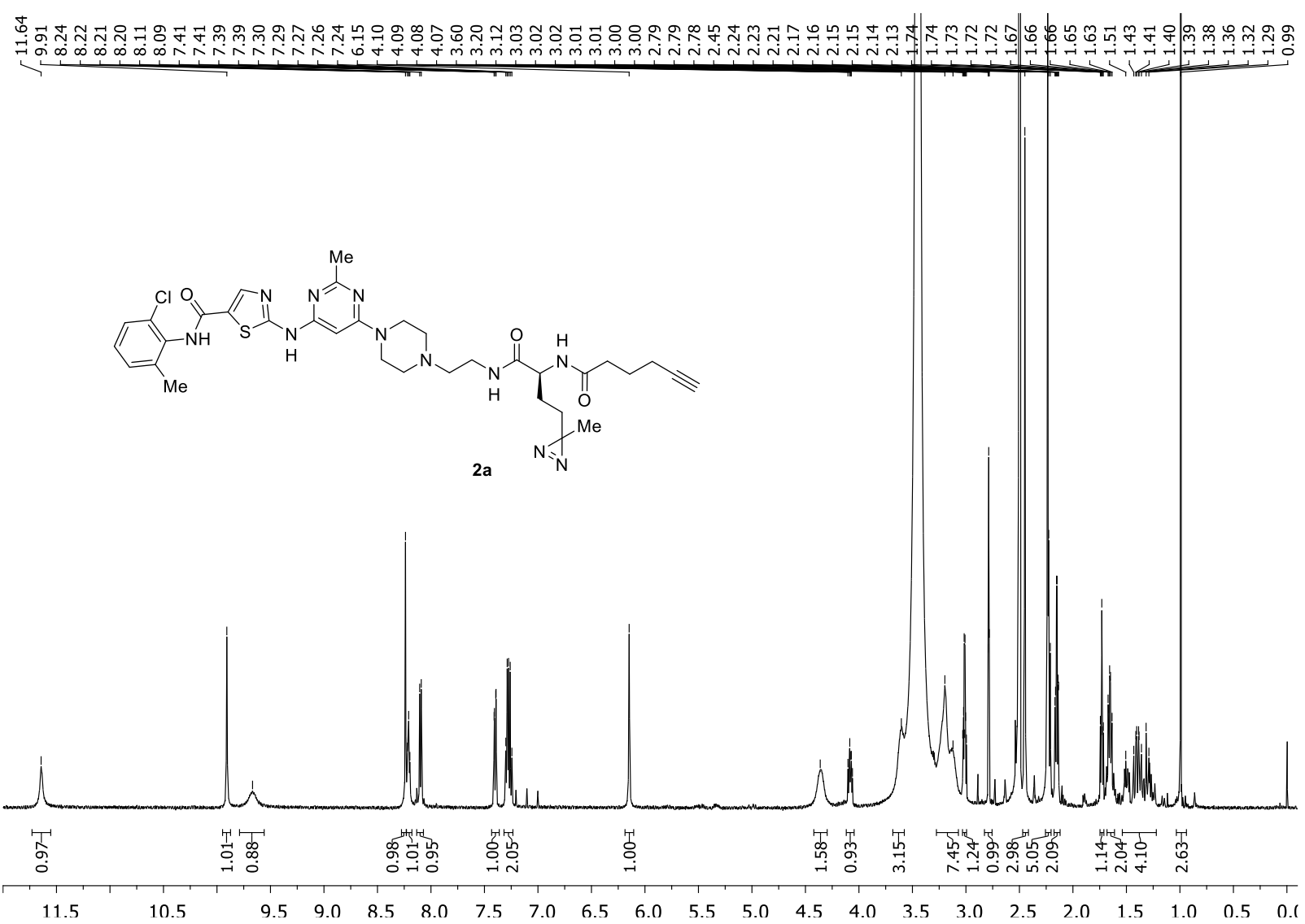



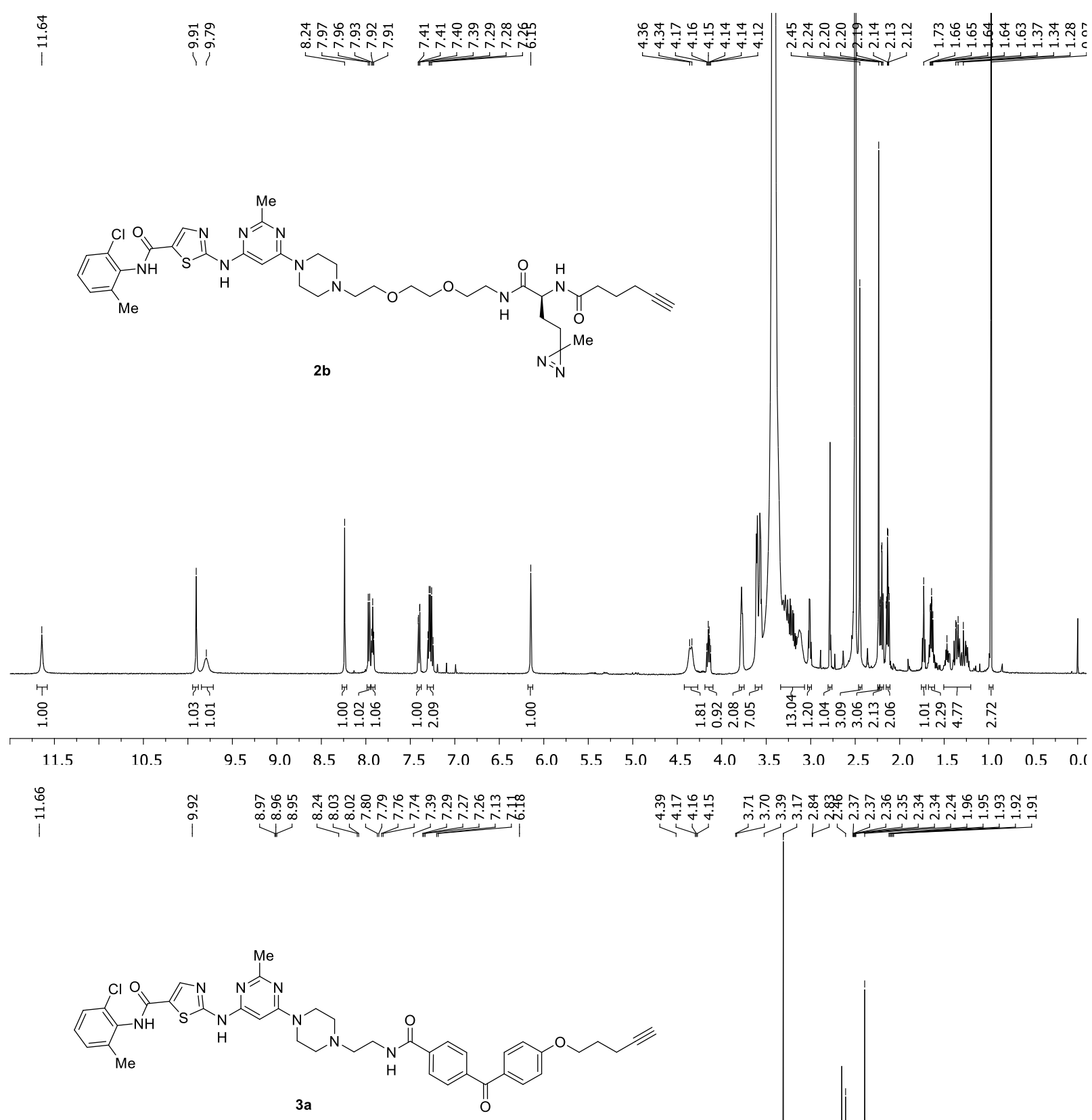

$3 a$

ن

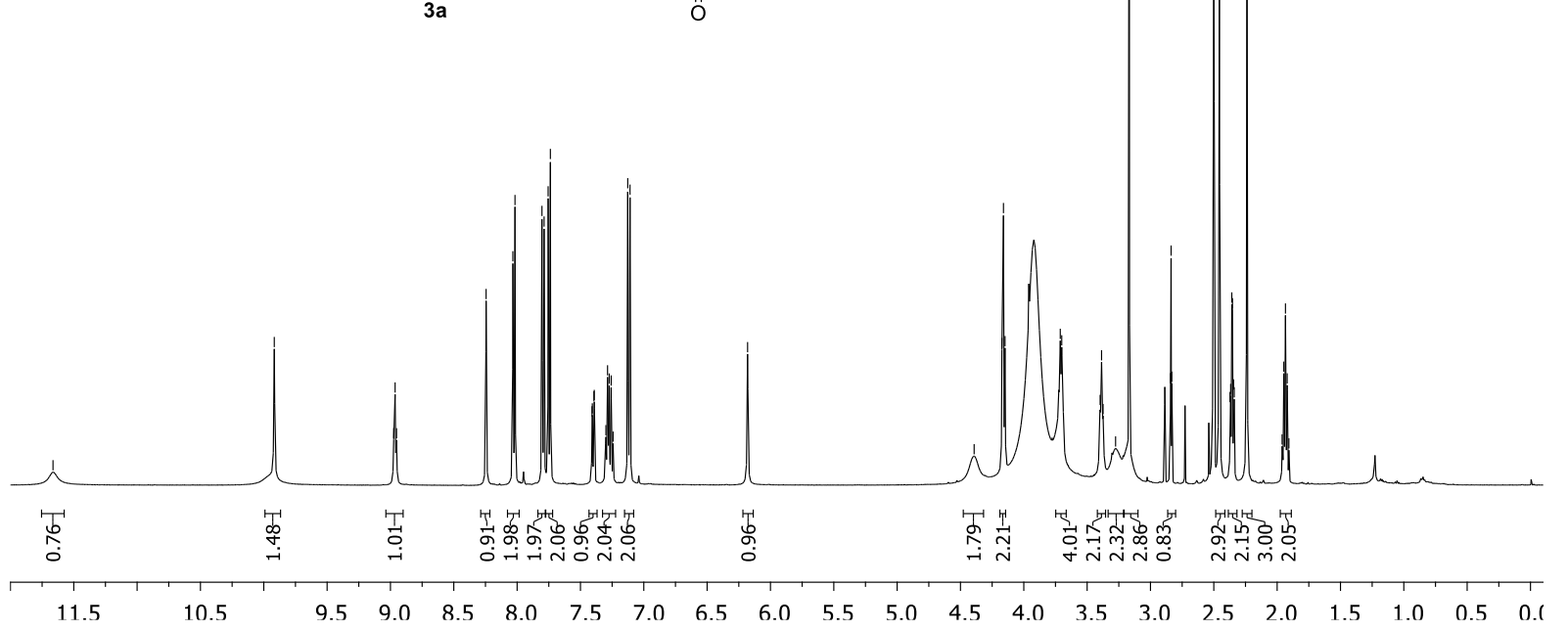




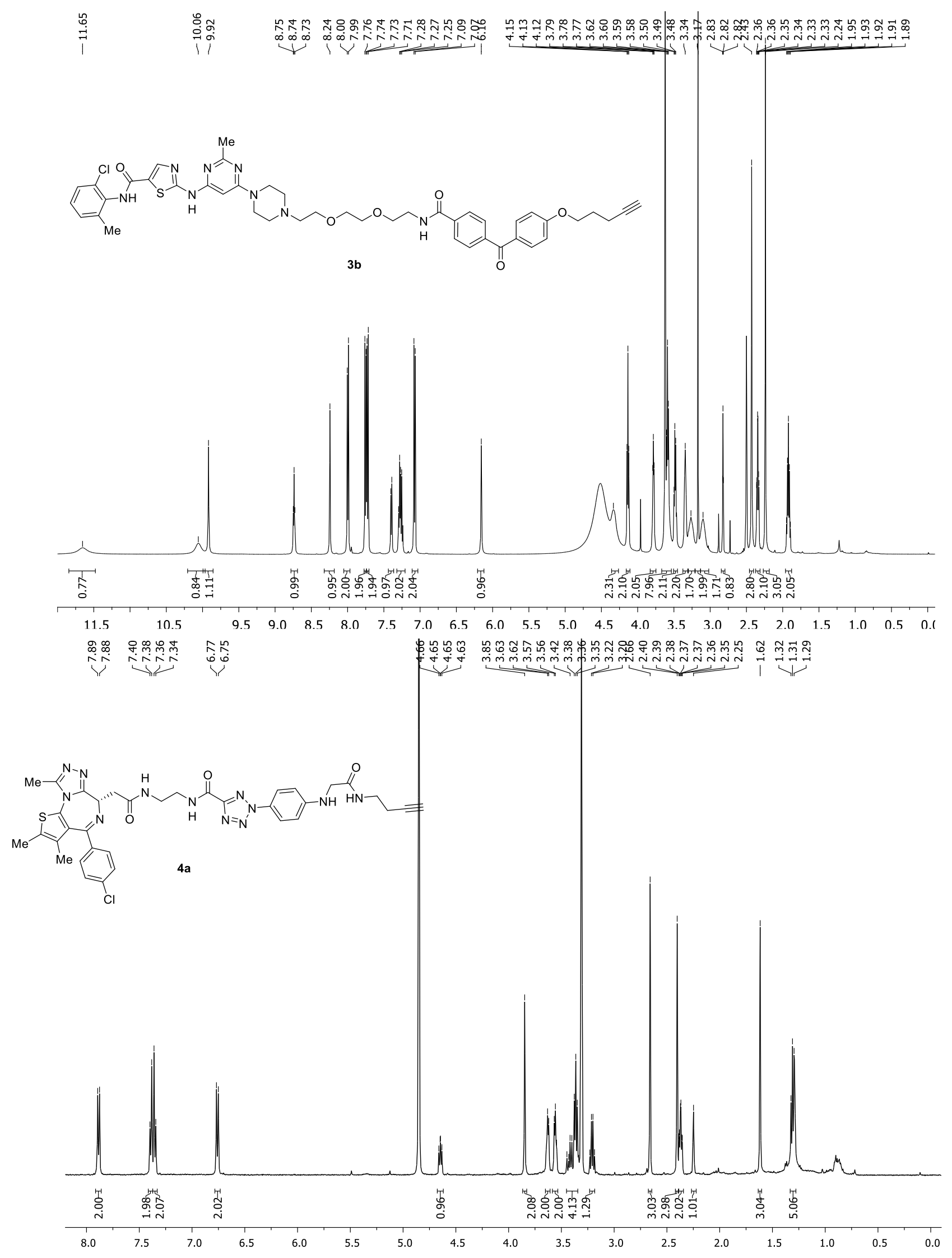




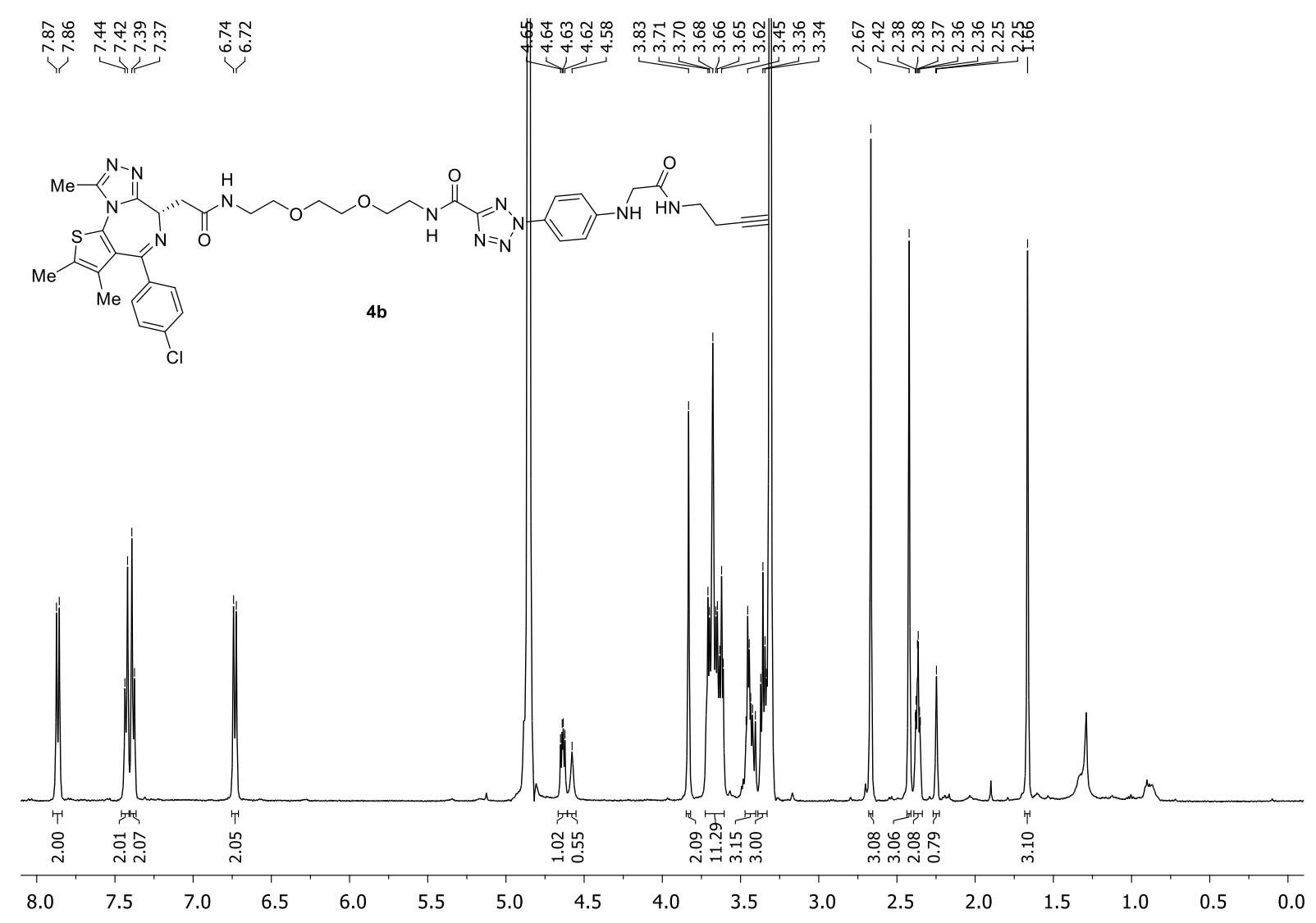

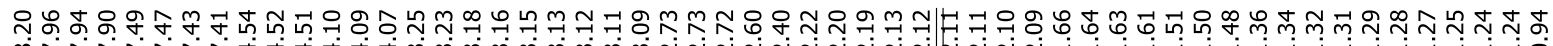

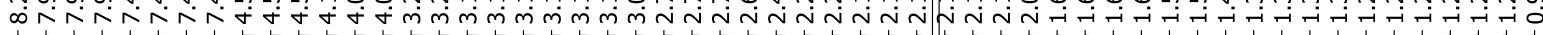
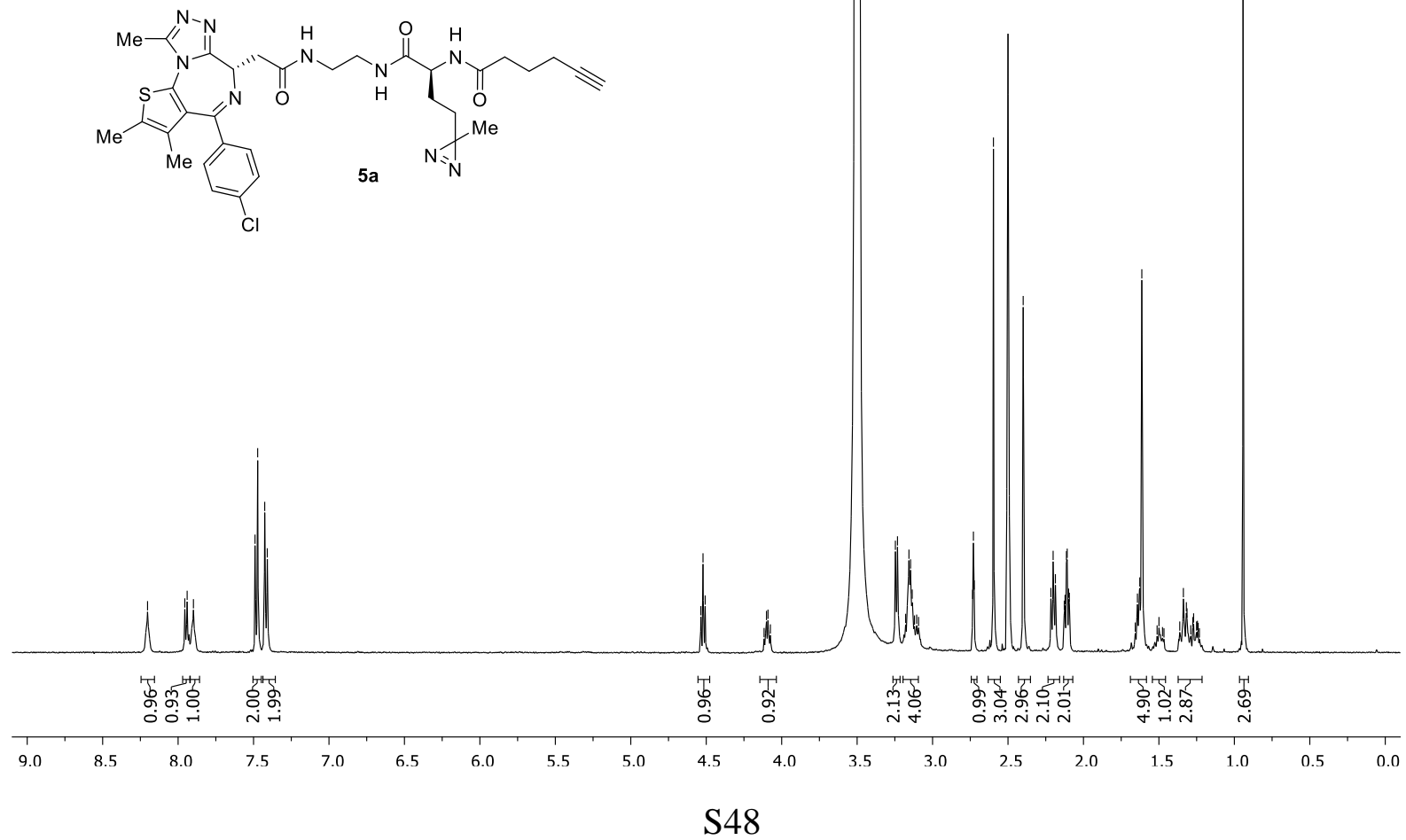


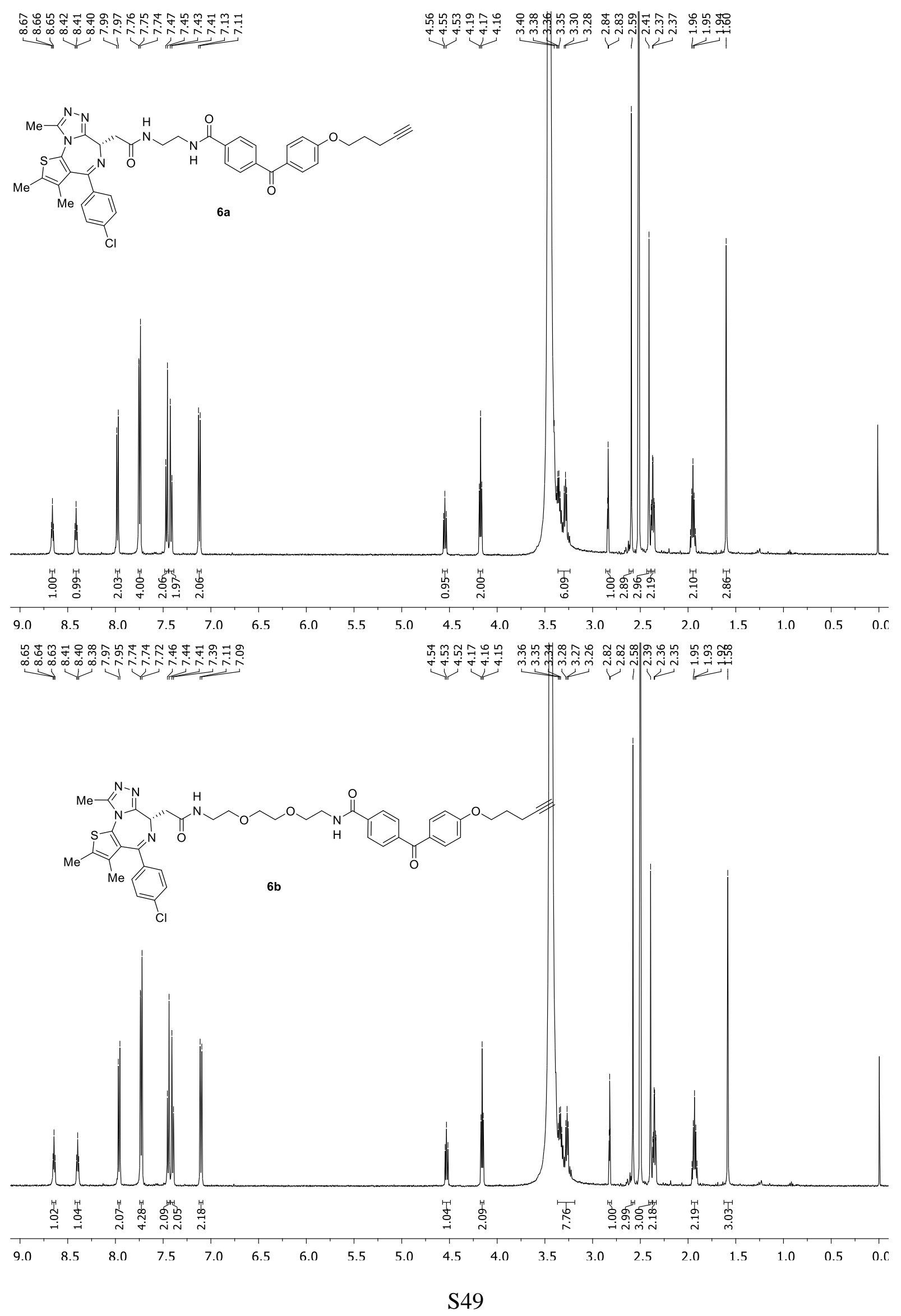

